U.S. Department of the Interior

U.S. Geological Survey

\title{
Surface-Water Quality-Assurance Plan for the Montana District of the U.S. Geological Survey
}

By M.K. White, R.R. Shields, and Kent A. Dodge

Open-File Report 98-173 


\section{U.S. Department of the Interior \\ BRUCE BABBITT, Secretary}

\section{U.S. Geological Survey}

Thomas J. Casadevall, Acting Director

Any use of trade, product, or firm name in this publication is for descriptive purposes only and does not imply endorsement by the U.S. Government

Helena, Montana

July 1998

For additional information write to:

District Chief

U.S. Geological Survey

Federal Building, Drawer 10076

Helena, MT 59626-0076

Copies of this report may be purchased from:

\section{U.S. Geological Survey}

Branch of Information Services

Box 25286

Denver, CO 80225-0286 


\section{CONTENTS}

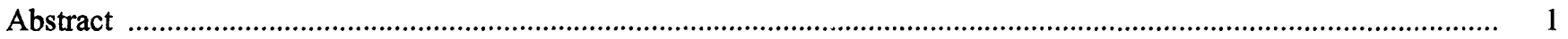

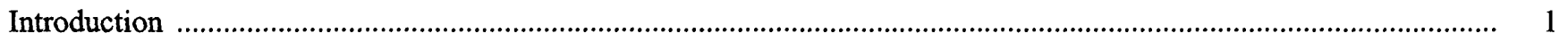

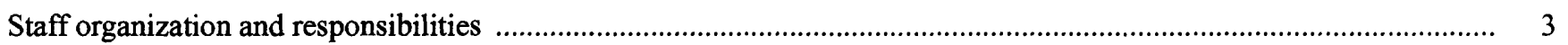

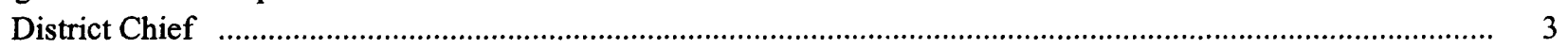

Chief, Hydrologic Surveillance and Analysis Section........................................................................ 5

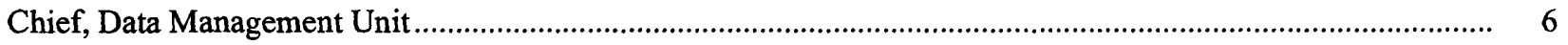

Field Headquarters Chiefs and Chief, International Waters Section ............................................................ 6

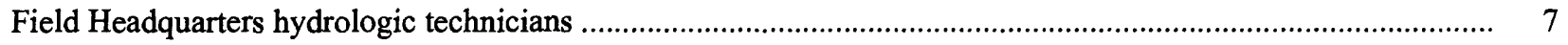

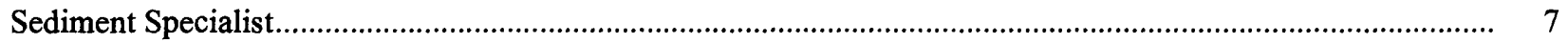

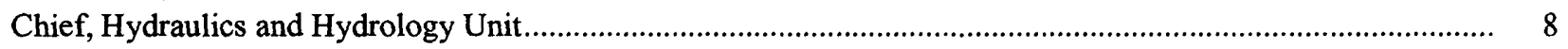

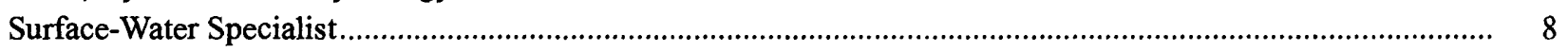

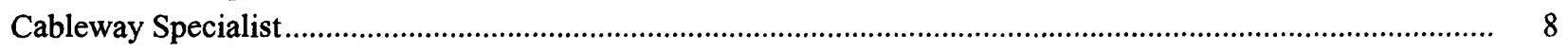

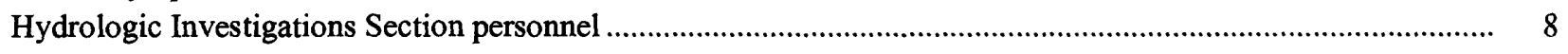

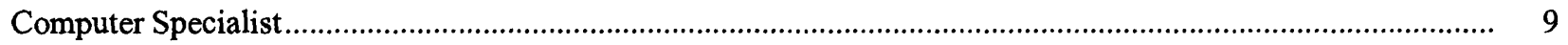

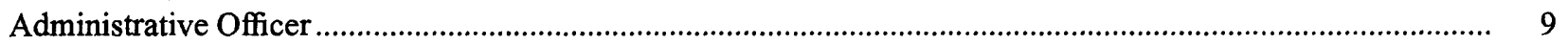

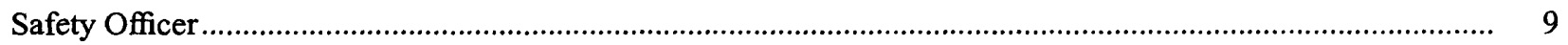

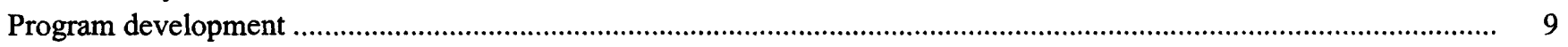

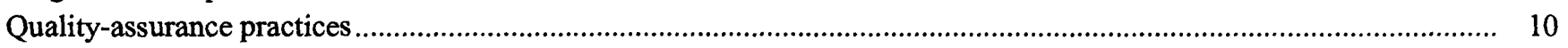

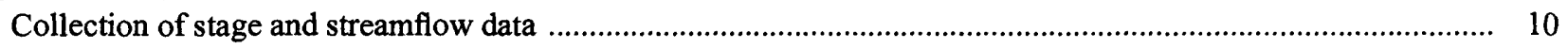

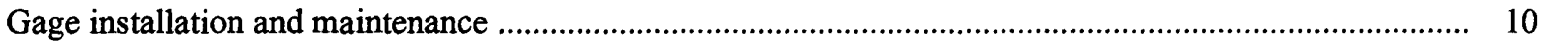

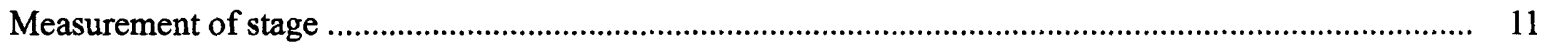

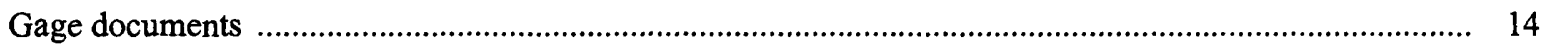

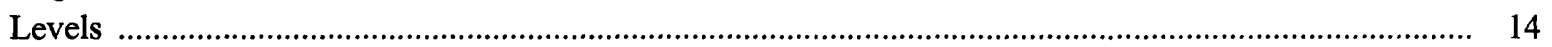

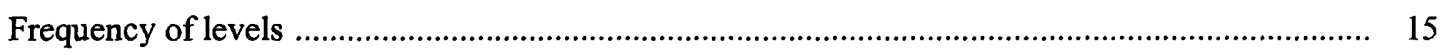

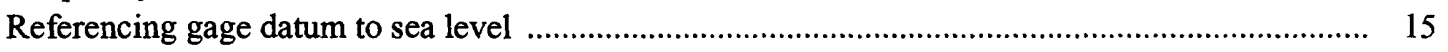

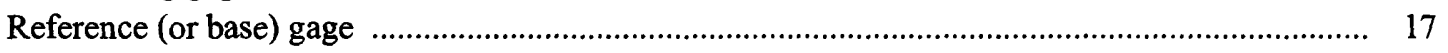

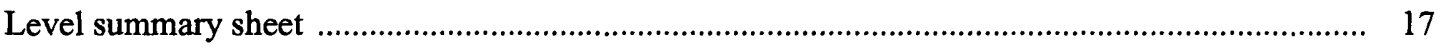

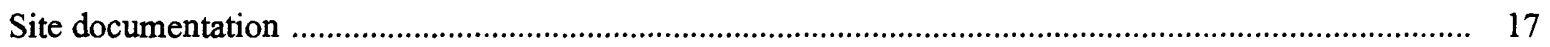

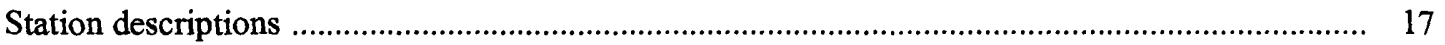

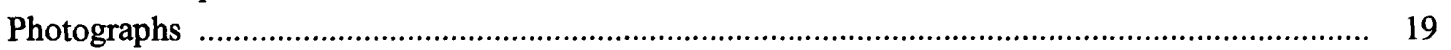

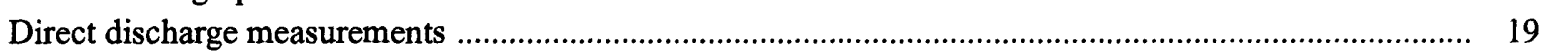

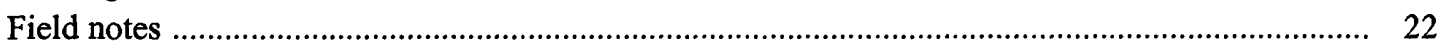

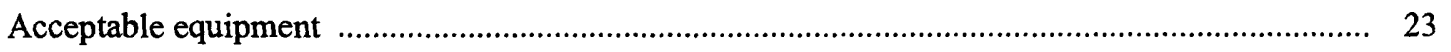

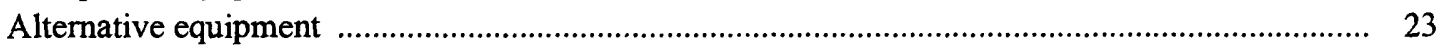

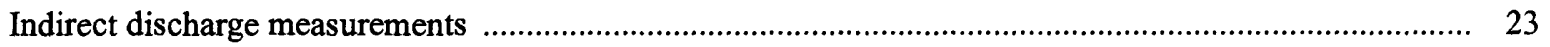

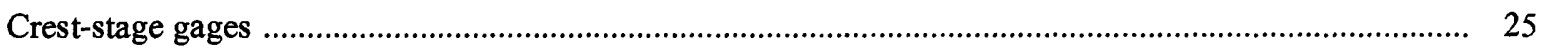

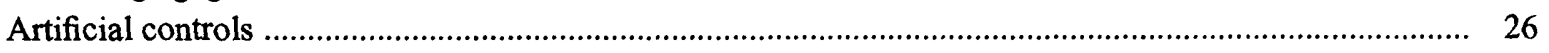

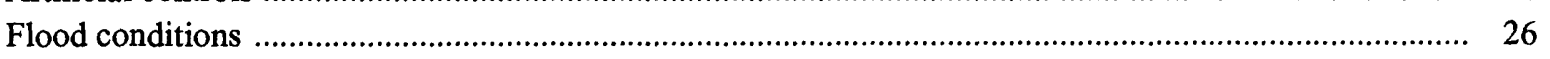

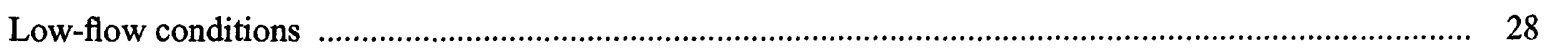

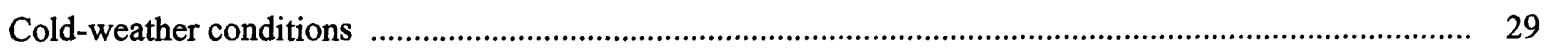

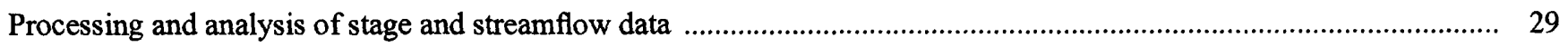

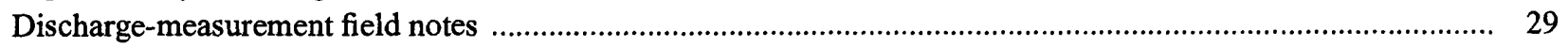

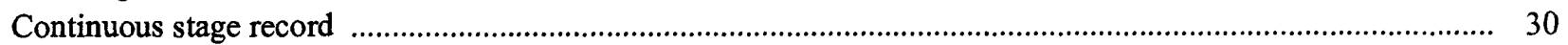

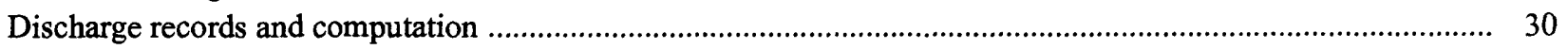

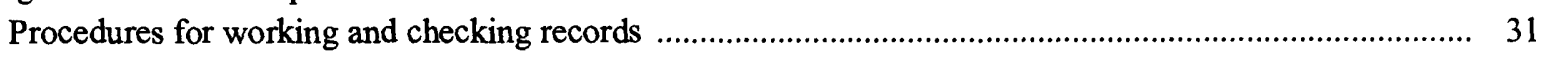

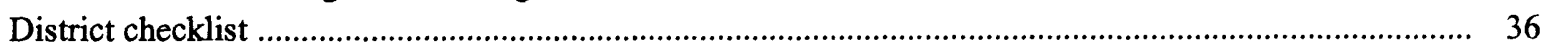

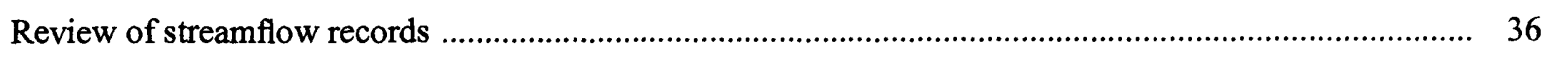




\section{CONTENTS--Continued}

Processing and analysis of stage and streamflow data--Continued

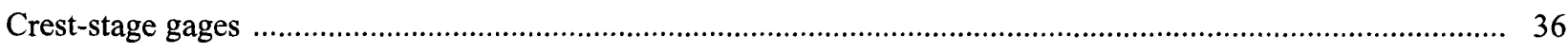

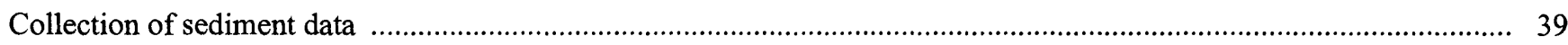

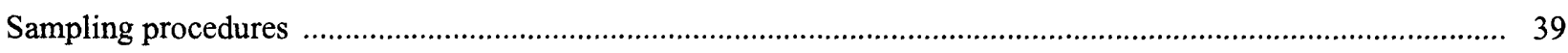

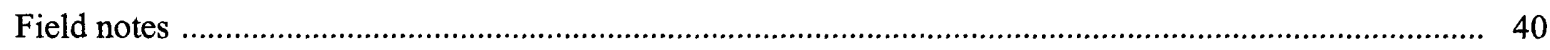

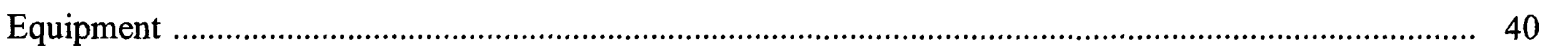

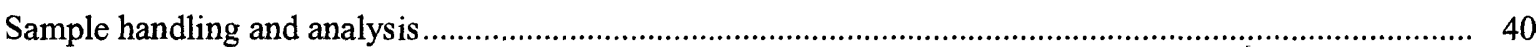

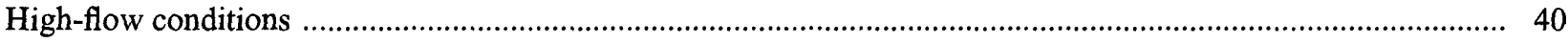

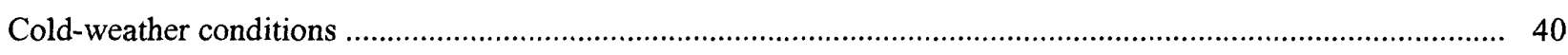

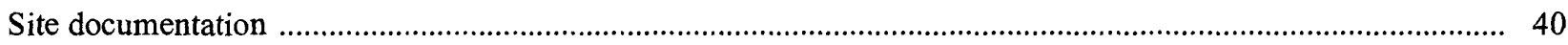

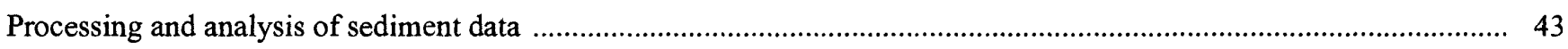

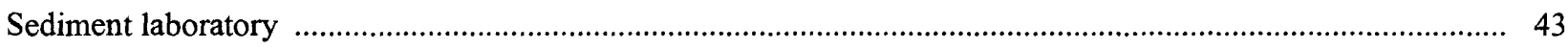

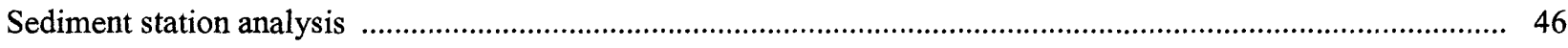

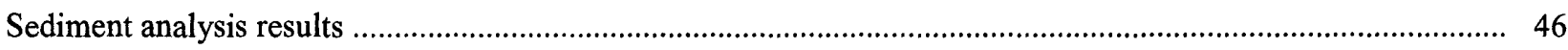

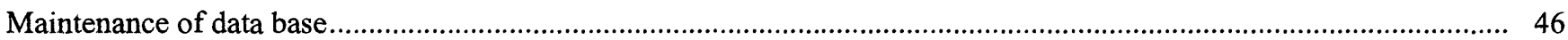

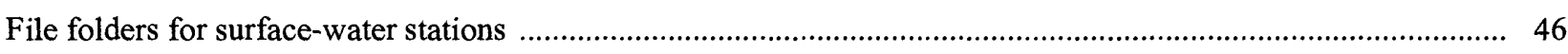

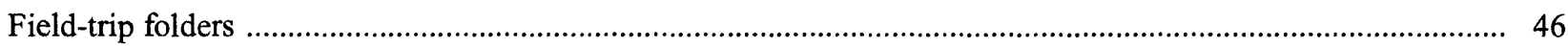

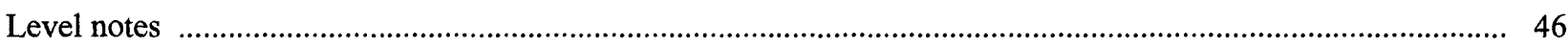

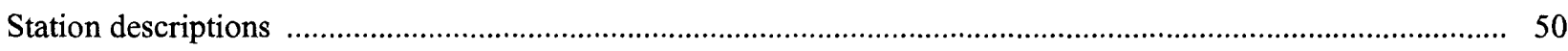

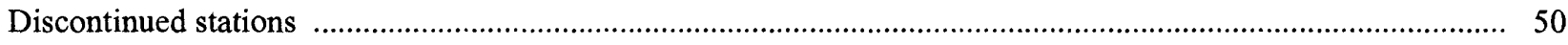

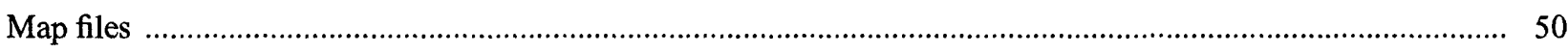

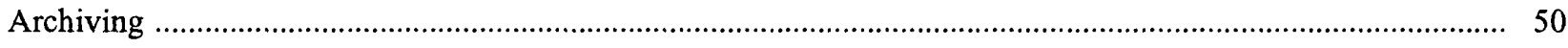

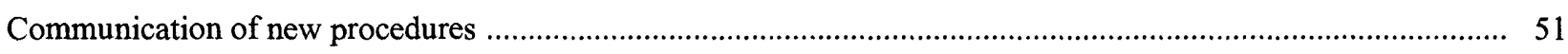

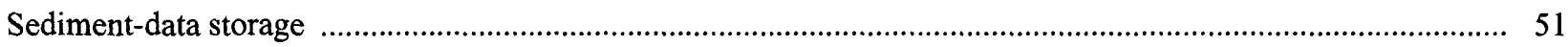

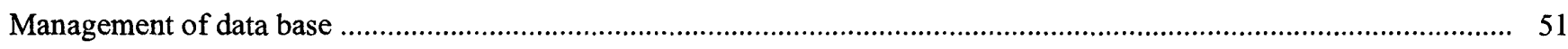

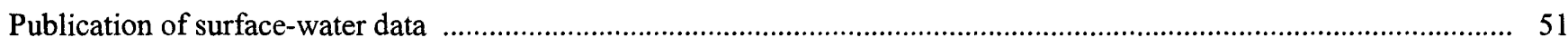

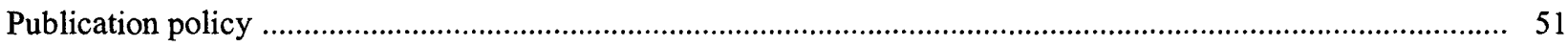

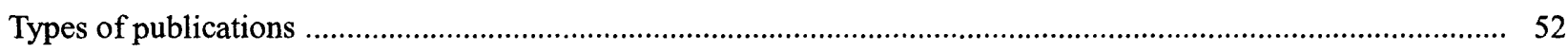

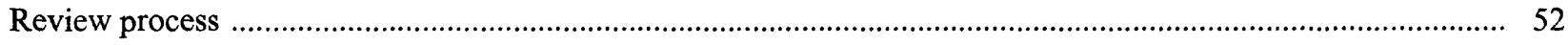

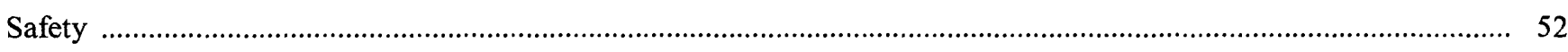

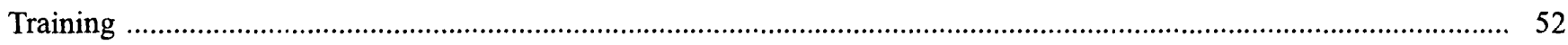

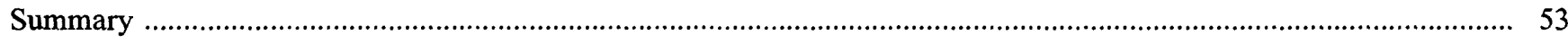

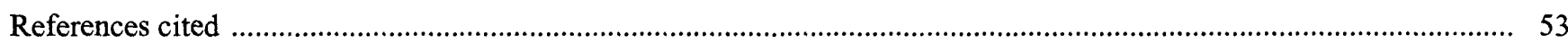

\section{ILLUSTRATIONS}

Figure 1. Organization chart of the Water Resources Division of the U.S. Geological Survey, 1998 .......................... 2

2. Organization chart of the Montana District, 1998 ........................................................................... 4

3. Map showing location of District and Field Headquarters Offices of the U.S. Geological Survey in Montana and general areas of responsibility 


\section{ILLUSTRATIONS---continued}

4-18. Example of:

4. Streamflow-gaging station and cableway safety inspection checklist ........................................ 12

5. Field form for recording levels at a streamflow-gaging station or crest-stage gage ........................... 16

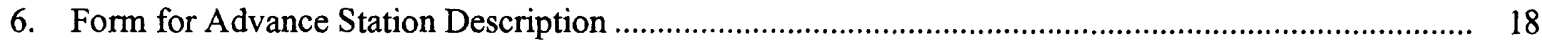

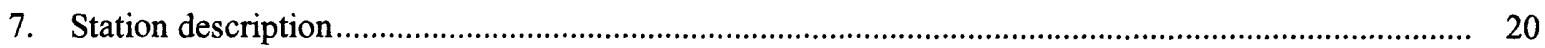

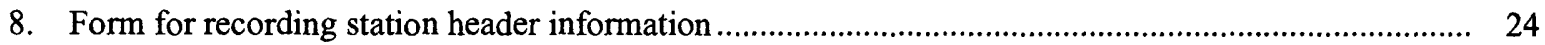

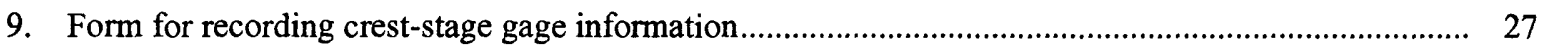

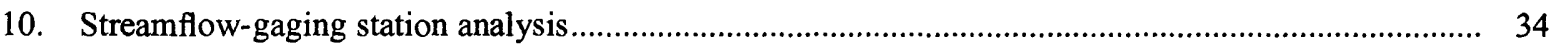

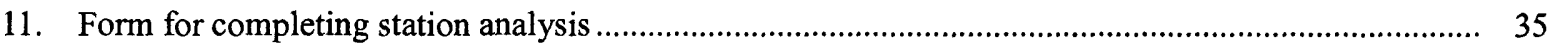

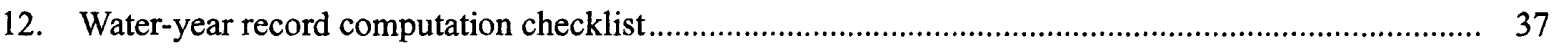

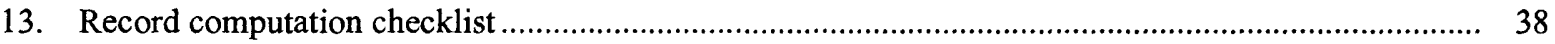

14. Surface-water quality sediment field notes ................................................................................. 41

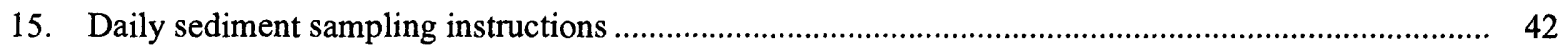

16. Water-year record sediment compilation checklist .................................................................... 44

17. Helena sediment laboratory annual quality-control chart ................................................................. 45

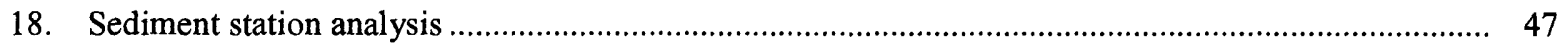

\section{CONVERSION FACTORS AND ACRONYMS}

Multiply By To obtain

$\begin{array}{rcl}\text { cubic foot per second }\left(\mathrm{ft}^{3} / \mathrm{s}\right) & 0.028317 & \text { cubic meter per second } \\ \text { foot }(\mathrm{ft}) & 0.3048 & \text { meter } \\ \text { inch }(\mathrm{in} .) & 25.4 & \text { millimeter } \\ \text { mile }(\mathrm{mi}) & 1.609 & \text { kilometer } \\ \text { square mile }\left(\mathrm{mi}^{2}\right) & 2.590 & \text { square kilometer }\end{array}$

Sea level: In this report "sea level" refers to the National Geodetic Vertical Datum of 1929 (NGVD of 1929)--a geodetic datum derived from a general adjustment of the first-order level nets of both the United States and Canada, formerly called Sea Level Datum of 1929.

Water-year: A water year is the 12-month period from October 1 through September 30. It is designated by the calendar year in which it ends.

Acronyms used in this report:

\begin{tabular}{|c|c|c|c|}
\hline ADAPS & Automated Data Processing System & OWQ & Office of Water Quality \\
\hline CSG & Crest-stage gage & QA & Quality assurance \\
\hline EDI & Equal Discharge Increment & TWRI & Techniques of Water-Resources Investigations of the \\
\hline FRC & Federal Records Center & USGS & U.S. Geological Survey \\
\hline GOES & Geostationary Operational Environmental Satellite & WATSTORE & Water data Storage and Retrieval system \\
\hline HIF & Hydrologic Instrumentation Facility & WRD & Water Resources Division, USGS \\
\hline OSW & Office of Surface Water & WWW & World Wide Web \\
\hline
\end{tabular}




\title{
SURFACE-WATER QUALITY-ASSURANCE PLAN FOR THE MONTANA DISTRICT OF THE U.S. GEOLOGICAL SURVEY
}

\author{
By M.K. White, R.R. Shields, and Kent A. Dodge
}

\section{Abstract}

This Surface-Water Quality-Assurance Plan documents the policies and procedures used by the Montana District of the U.S. Geological Survey to maintain quality in all aspects of surface-water activities. Use of the information included in this report assures high quality in the collection, processing, analysis, maintenance, management, and publication of surface-water data. The roles and responsibilities of District personnel in following these policies and procedures are presented, as are issues related to employee safety and training.

\section{INTRODUCTION}

The U.S. Geological Survey (USGS) was established by Congress on March 3, 1879, to provide for the systematic and scientific "classification of the public lands, and examination of the geologic structure, mineral resources, and products of the national domain." Surface-water activities in the Montana District are part of the Water Resources Division's (WRD) (fig. 1) overall mission of appraising the Nation's water resources. Surface-water information, including streamflow, stage, and sediment data, are used at the Federal, State, and local levels for resources planning and management.

The purpose of this Surface-Water QualityAssurance Plan is to document the policies and procedures used by the Montana District to maintain quality assurance (QA) in all aspects of surface-water activities. This plan outlines the field and office responsibilities of District personnel for assuring the technical quality and reliability of data. The QA plan is based on the following principles and observations:

1. Ultimately, the quality of District data depends on the care, concern, skill, and initiative of all individuals involved in the data collection, analysis, and publication. Pride in workmanship is essential.
2. Effective implementation of a QA plan requires clear communication of the goals of the plan, the standards on which the plan is based, and individual and management responsibilities; identification of a followup process for corrective action and feedback; and commitment at all levels of management to secure the required resources, training, equipment, and administrative support.

Quality-assurance practices that are used to maintain, evaluate, and improve data quality include:

1. District surface-water programs and projects are planned to efficiently and effectively provide information necessary to study local, State, national, and international surface-water conditions within the WRD sphere of competence and responsibility.

2. Field and office work are performed in accordance with specified WRD standards as outlined in Techniques of WaterResources Investigations (TWRI's), policy memorandums, the Montana District Surface-Water Manual, international treaties, the Yellowstone River Compact, and individual employee performance plans. Policy memorandums and the Montana District Surface-Water Manual are in-house documents and available by contacting the District Chief or the Chief, Hydrologic Surveillance and Analysis Section (HSAS).

3. Field and office work are performed by qualified, experienced, and properly supervised personnel.

4. Surface-water activities and procedures receive appropriate and timely review for completeness, accuracy, and conformance to specified standards. 


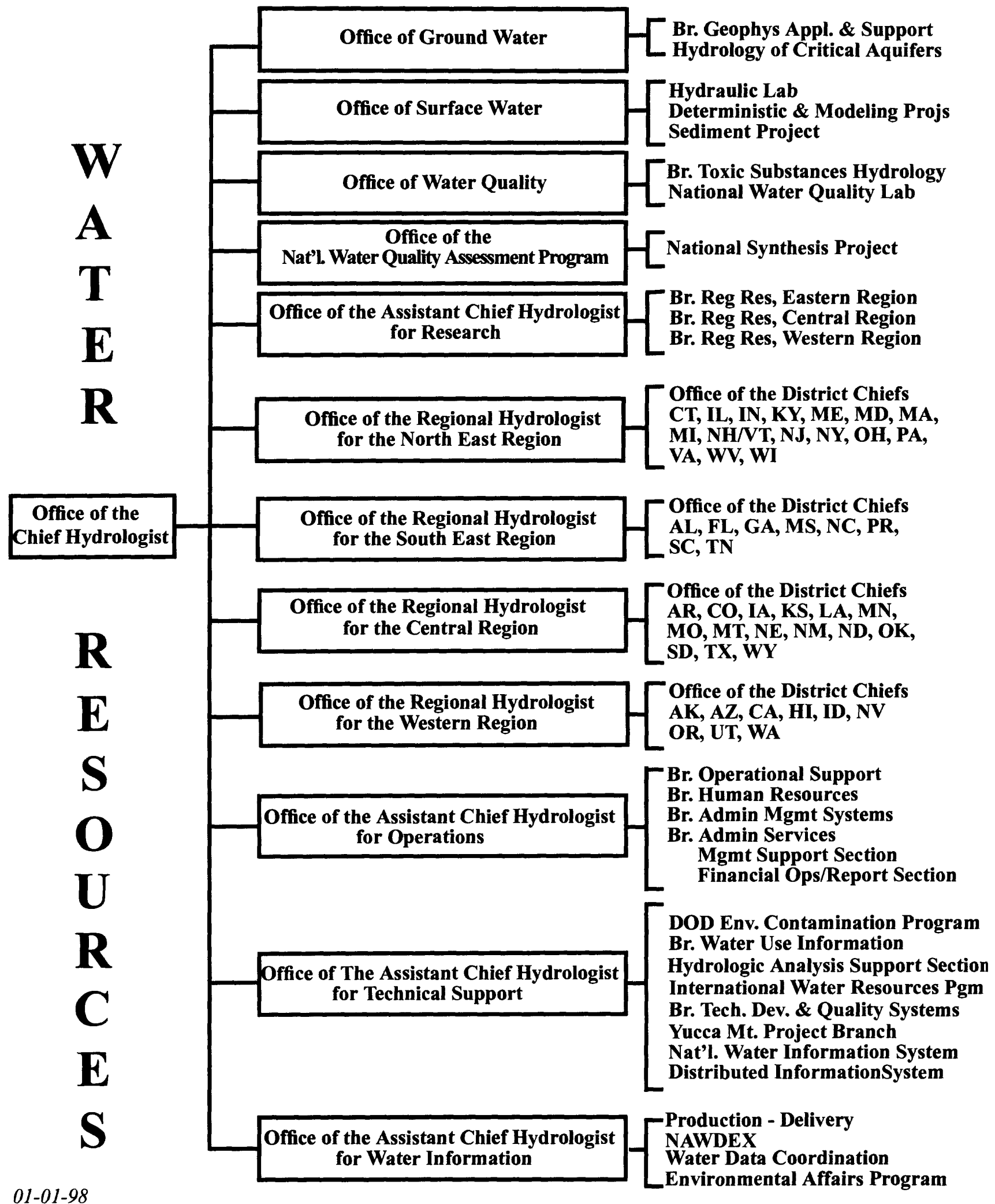

$01-01-98$

Figure 1. Organization chart of the Water Resources Division of the U.S. Geological Survey, 1998. 
5. Remedial actions are taken to correct any observed or suspected deficiencies in program or project activities.

6. All individuals involved in surface-water activities are responsible for implementing quality assurance. Field Headquarters supervisors and project leaders assume much of the responsibility; however, the District Chief has the final responsibility.

The scope of this report includes description of the policies and procedures followed by this District for the collection, processing, analysis, maintenance, management, and publication of surface-water data. Quality-assurance practices are discussed for specific surface-water activities pertaining to the collection, management, and dissemination of stage, streamflow, and sediment data. In addition, issues related to employee safety and training are presented.

\section{STAFF ORGANIZATION AND RESPONSIBILITIES}

The Montana District is organized into three operational sections and three support units (fig. 2). The operational sections include the Hydrologic Surveillance and Analysis Section (HSAS), the International Waters Section, and the Hydrologic

Investigations Section. The support units include the Administrative Services Unit, the Computer Services Unit, and the Publications Unit. The operational sections are organized by Field Headquarters offices and various operational units. Individual personnel are assigned as discipline specialists and management advisors.

The Montana District conducts its surface-water program within Montana and Canada through the HSAS and the International Waters Section. Surfacewater data-collection personnel within the Montana District are primarily located in four Field Headquarters offices and the District Office in Helena (fig. 3). The primary responsibility for ensuring that surfacewater programs in the Montana District are adequately planned rests with the District Surface-Water Specialist and the District's senior staff including the District Chief, who serves as the chairperson; the Assistant District Chief; the Chief, Hydrologic Investigations Section; the Chief, HSAS; and the Administrative Officer. Members of the senior staff and the Surface-Water Specialist contribute their specialized knowledge to the formulation of policies and plans for short- and longterm programs and to the establishment of criteria for determining the type and scope of surface-water activities to undertake.

This QA plan is reviewed and revised at least once every 3 years by the Chief, HSAS. The review and revision ensure that responsibilities and methodologies are kept current and that the ongoing procedural improvements are effectively documented.

Achieving and maintaining high-quality standards for surface-water data is an ongoing process, accomplished by specific actions of various persons. Errors and deficiencies can result when individuals fail to complete their responsibilities or do not understand their roles or the roles of others. Clear and specific statements of responsibilities promote an understanding of each person's duties in the overall process of assuring quality of surface-water data.

Work plans, which are used as general guides for individual responsibilities and duties, are prepared for each person in the District. The work plans typically contain universal statements allowing flexibility in accomplishing tasks, but are sufficiently structured to list elements needed to complete tasks. The Chief, HSAS, Field Headquarters Chiefs, and Chief, Data Management Unit communicate frequently with field personnel to inform them of assignments and priorities. As a result, the Montana District commonly uses an informal, verbal system of assignments.

Field Headquarters Chiefs are responsible for daily operations. They assign work according to an employee's knowledge and experience and are responsible for ensuring quality control, QA, and safety of employees, whether in the field or in the office.

The following is a list of responsibilities for District personnel who are involved in the collection, processing, analysis, maintenance, management, or publication of surface-water data.

\section{District Chief}

\section{The District Chief is responsible for:}

1. Managing and directing the District program, including all surface-water activities, and delegating, where applicable, surface-water activities to the Chief, HSAS; the International Waters Section; and the Hydraulics and Hydrology Unit.

2. Ensuring that surface-water activities in the District meet the needs of the Federal Government, the Montana District, State and local agencies, other cooperating agencies, and the general public. 


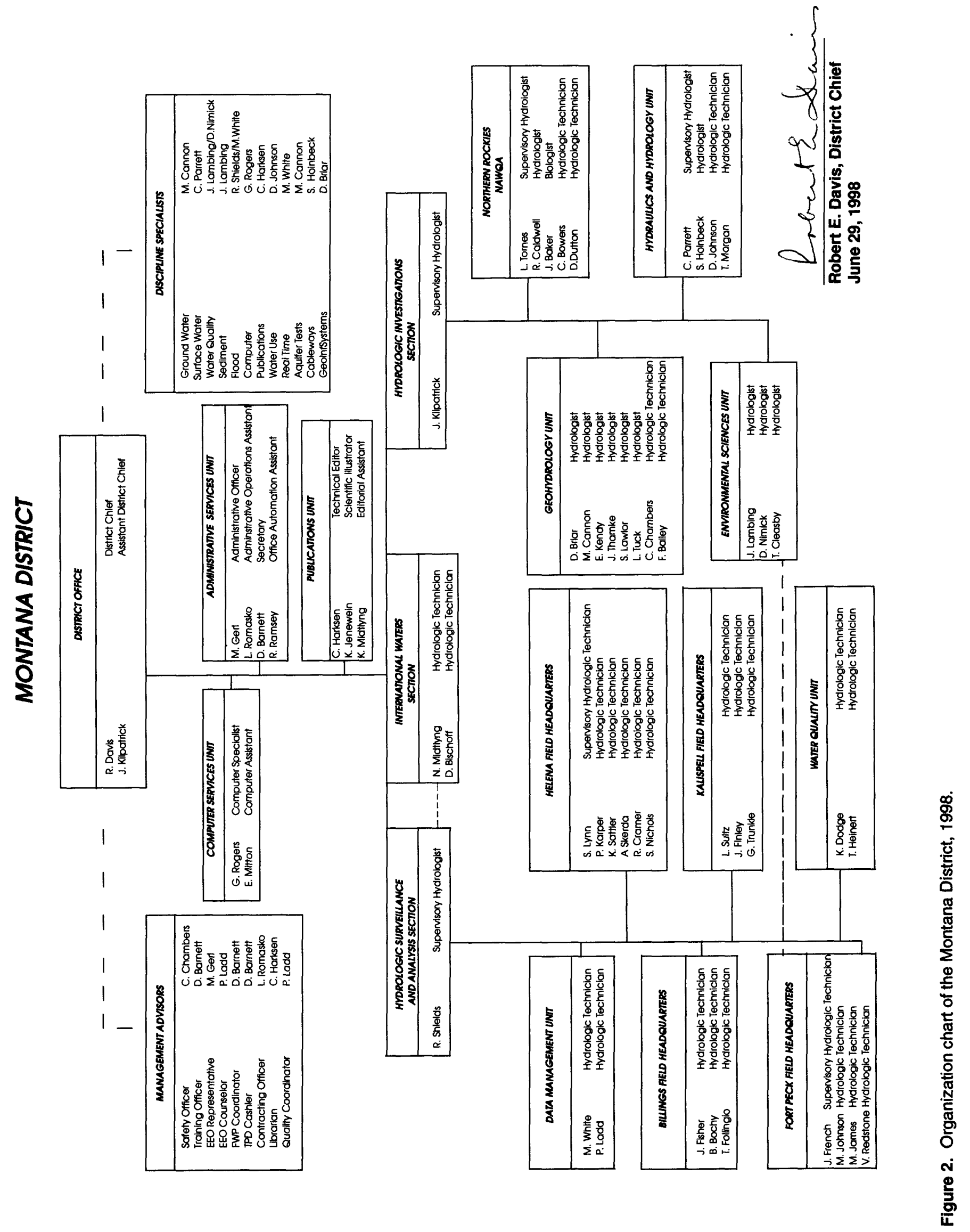




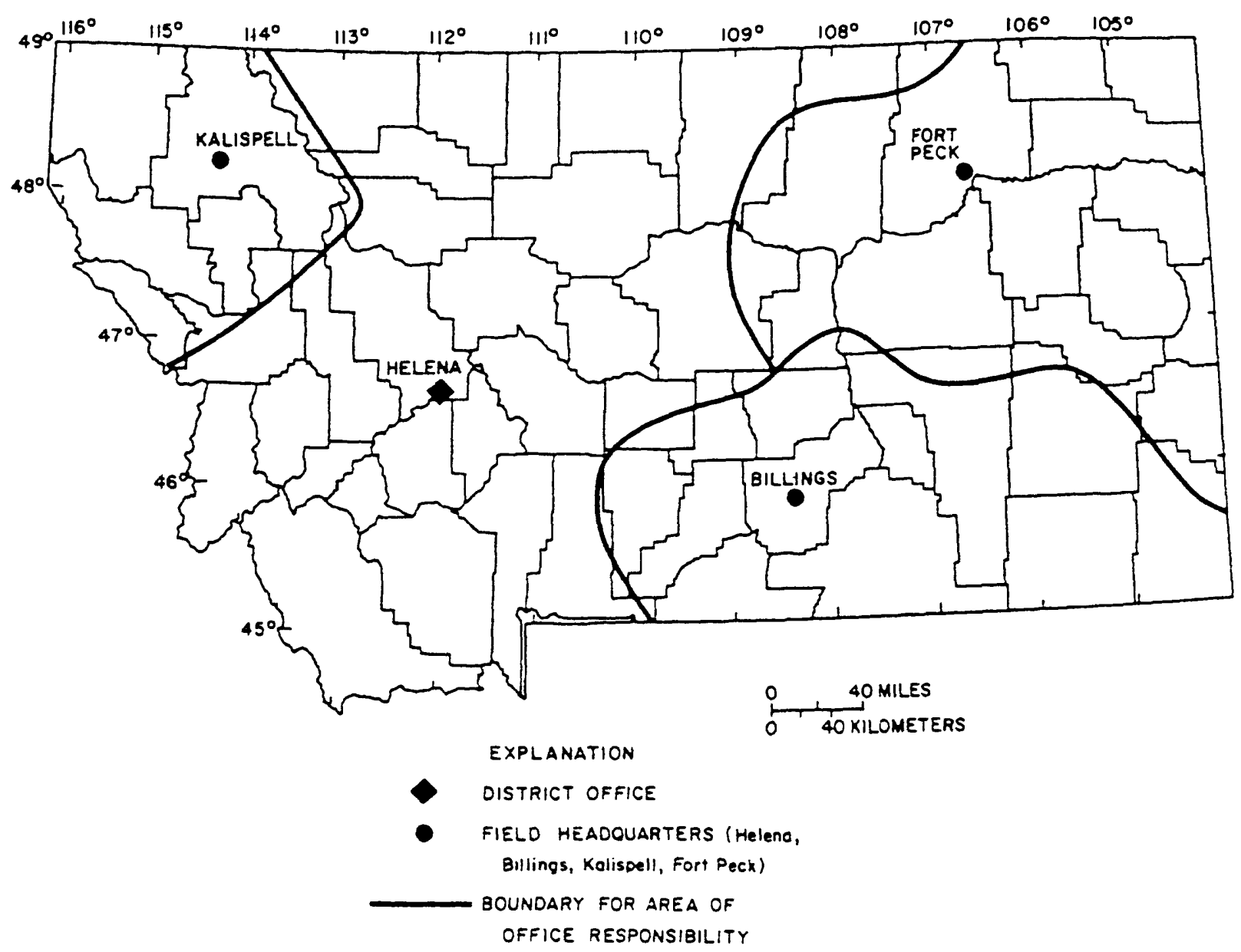

Figure 3. Location of District and Field Headquarters Offices of the U.S. Geological Survey in Montana and general areas of responsibility.

3. Ensuring that all aspects of this QA Plan are understood and followed by District personnel. This responsibility is fulfilled by the District Chief's direct involvement or through clearly stated delegation to other personnel in the District.

4. Keeping personnel briefed on surface-water procedural and technical communications from Region Offices and WRD Headquarters.

5. Ensuring that all surface-water publications and other technical surface-water communications released by the District are accurate and in accord with USGS policy.

6. Ensuring on-the-job safety and health of all District personnel.

7. Reviewing and approving surface-water records for the Boundary Waters Treaty of 1909, as the Field Representative for the Accredited Officer of the United States.

8. Participating in outreach programs to promote the visibility of the USGS.

\section{Chief, Hydrologic Surveillance and Analysis Section}

The Chief, HSAS is responsible for:

1. Managing and supervising the collection, processing, and publication of surface-water hydrologic data in Montana. This statewide program includes collecting streamflow and water-quality (including sediment) data and publishing the information in the annual water data report, "Water Resources Data, Montana."

2. Managing and directing the work of the Section, which consists of the Data Management Unit, Water Quality Unit, and four Field Headquarters located in Billings, Fort Peck, Kalispell, and Helena.

3. Reviewing, evaluating, and advising surface-water personnel on the technical adequacy of the methods of collection, analysis, and interpretation of hydrologic data intended for technical reports. 
4. Ensuring the development and implementation of QA plans and procedures for the collection and processing of hydrologic data.

5. Serving as co-advisor, with the SurfaceWater Specialist, to the District Chief and project chiefs on the collection, processing, and publication of hydrologic data.

6. Participating with the District Chief and other staff members in planning and developing hydrologic-data programs and interpretive studies, some in cooperation with State and other Federal agencies.

7. Managing and conducting investigations in selected aspects of the surface-water discipline, including instrumentation and field and office procedures to facilitate the work of the HSAS.

8. Ensuring that all reports prepared by the HSAS meet USGS publications guidelines.

9. Serving as a District contact for cooperating agencies and answering information inquiries from cooperating agencies and the general public.

10. Ensuring on-the-job safety and health of all supervised employees.

11. Participating in outreach programs to promote the visibility of the USGS.

\section{Chief, Data Management Unit}

The Chief, Data Management Unit is responsible for:

1. Maintaining the District's electronic and archived paper files of streamflow and water-quality records; performing technical and editorial review of streamflow and water-quality records published in the annual data report, "Water Resources Data, Montana"; submitting reviewed surfacewater data to WRD Headquarters for inclusion in the Water data Storage and Retrieval (WATSTORE) system data base; answering requests for surface-water and water-quality data from other agencies and from the general public; providing technical review of interpretive or data reports related to streamflow or water-quality data; working with Field Headquarters Chiefs and other District personnel in the acquisition and compilation of surface-water data; and serving as the District contact for the HSAS in the absence of the Chief, HSAS.

2. Serving as the District coordinator for the real-time surface-water data program, including determining data requirements for existing and new real-time surface-water stations, reviewing and verifying incoming real-time data, and monitoring real-time data for inclusion on the District's World Wide Web (WWW) Home Page.

3. Assisting the Computer Specialist as the Automated Data Processing System (ADAPS) data base administrator.

4. Coordinating site visits of USGS personnel during floods or other unusual or high-water events, and compiling the collected data; apprising District, Regional, and WRD Headquarters staff of current events using electronic media; sending press releases to local and national news media to disseminate data and to inform the public of realtime streamflow conditions; and coordinating among USGS, National Weather Service, Natural Resources Conservation Service, and other Federal and State agencies.

\section{Field Headquarters Chiefs and Chief, International Waters Section}

The Field Headquarters Chiefs and Chief, International Waters Section are responsible for:

1. Ensuring timely performance and satisfactory quantity and quality of work.

2. Reviewing, accepting, amending, or rejecting the work performed.

3. Advising employees on technical matters.

4. Providing final technical review of surfacewater records; assisting and advising personnel in the computation of surface-water records using knowledge of the basins and knowledge of surface-water hydrology to ensure that QA is maintained; and using appropriate mathematical and statistical methods to analyze hydrologic and related data. 
5. Making or assigning others to make direct measurements of streamflow, measuring water levels in wells, collecting other hydrologic and meteorological data from many sources, and collecting water-quality samples (chemical, biological, or sediment) using various instruments.

6. Performing or reviewing complex direct and indirect discharge measurements requiring the proper application of complex hydraulic formulas.

7. Performing reconnaissance and surveying locations for new streamflow-gaging stations, and reviewing plans for design and construction of these stations, including installation of scientific recording equipment, artificial controls, cableways, and other equipment associated with gaging-station structures.

8. Applying computer-based techniques to solve hydrologic problems, including data acquisition, management, and analysis.

9. Preparing reports for use by the USGS, other Federal and State agencies, and the public.

10. Representing the District when conducting surface-water related business with cooperating agencies and the general public.

11. Ensuring on-the-job safety and health of all supervised employees.

\section{Field Headquarters Hydrologic Technicians}

Field Headquarters hydrologic technicians are responsible for:

1. Developing stage-discharge ratings at gaging stations by measuring stream discharge at various stages.

2. Preparing plans for new streamflow-gaging stations, artificial controls, cableways, and other equipment associated with streamgaging structures and for the rehabilitation of existing stations; making reconnaissance and surveys for the location of new streamflow-gaging stations; preparing orders for materials and cost estimates of major construction and repair jobs; and procuring materials.
3. Installing, servicing, and maintaining all types of stream-gaging equipment and recording instruments, including data-collection platforms for data transmission to Geostationary Operational Environmental Satellites (GOES).

4. Running level circuits to establish or to check gage reference datums or peak stages from high-water marks.

5. Computing discharge records for streamflow-gaging stations using the stage-discharge relation and stage record; reviewing the development of stage-discharge curves relative to channel condition and measurement trends to determine appropriate shifts; reviewing and checking accumulated data to determine the accuracy of results obtained at streamflow-gaging stations; recommending improvements in techniques and methods; writing station analyses that describe the annual streamflow characteristics and the procedures used to compute discharge records; and preparing data in final publication format.

6. Independently making onsite measurements of water-quality field parameters; planning and conducting water-quality sampling involving chemical, physical, and biological parameters, and directing lower-graded employees assisting with sampling; computing data for publication; and checking work performed by other employees.

7. Preparing plans for, constructing, and maintaining water-quality sampling structures and rebuilding installations that have been destroyed or damaged; inspecting and maintaining the various types of samplers and related equipment; and preparing orders and purchasing necessary materials.

8. Informing first-line supervisor; or Chief, HSAS; or Chief, Data Management Unit when conditions noted in the field are unusual, such as high water or extreme backwater conditions, gage equipment malfunction, or rating change.

\section{Sediment Specialist}

The District Sediment Specialist is responsible for: 
1. Managing and directing sediment datacollection programs--including proposal preparation and sampling plans, data collection and interpretation, report writing and review, and maintaining contact with District management, colleagues, cooperators, and the general public; and representing the District in sediment issues, providing technical oversight of sediment activities of the District, and ensuring the adequacy of quality-control programs for sediment data collection and processing.

2. Directing Field Headquarters personnel in their assigned sediment responsibilities.

3. Providing technical oversight of sediment data-processing services performed by Data Management Unit personnel. These services include QA, screening laboratory analytical reports, entering sediment data into District and national computer files, and preparing sediment data for inclusion in the annual data report.

4. Providing technical oversight of the District sediment laboratory which, through a designated laboratory supervisor, provides analyses of suspended-sediment concentration and particle size to the District and Field Headquarters offices.

5. Ensuring on-the-job safety and health of all supervised employees.

\section{Chief, Hydraulics and Hydrology Unit}

The Chief, Hydraulics and Hydrology Unit is responsible for:

1. Managing and supervising the personnel in the Unit.

2. Approving indirect streamflow measurements.

3. Approving the crest-stage gage computations and records.

4. Managing the peak-flow and basin-characteristics data bases.

5. Serving as District contact for cooperating agencies and answering information inquiries from Federal and cooperating agencies and the general public.

6. Participating with the District Chief and other staff members in planning and devel- oping hydrologic-data programs and interpretive studies, some in cooperation with State and other Federal agencies.

7. Managing and conducting investigations in selected aspects of the surface-water discipline, including complex hydrologic and hydraulic analyses using various statistical methods and hydraulic engineering principles.

\section{Surface-Water Specialist}

The Surface-Water Specialist is responsible for:

1. Advising on the technical adequacy of surface-water programs.

2. Serving as technical advisor concerning surface-water activities to the senior staff and other District personnel.

3. Reviewing project work plans and reports for technical adequacy of methodology, appropriate application of methodology, validity of supporting data, and conclusions relating to surface-water activities.

\section{Cableway Specialist}

The Cableway Specialist is responsible for:

1. Serving as technical advisor concerning cableway designs and construction techniques to the senior staff and other District personnel.

2. Advising personnel about requirements for inspections and documentation of construction history and maintenance.

3. Reviewing and approving cableway designs.

\section{Hydrologic Investigations Section Personnel}

Personnel of the Hydrologic Investigations Section are available to provide assistance during periods of peak streamflow or other hydrologic events. When the need arises, personnel from the HSAS will contact the Chief, Hydrologic Investigations Section to request assistance. The assisting personnel generally will accompany Field Headquarters personnel to ensure timely and safe data 
collection. These field assignments can vary from 1 day to more than a week.

\section{Computer Specialist}

The Computer Specialist is responsible for:

1. Ensuring that data integrity is preserved by performing regular backup of data files; ensuring that archived data, such as historical unit-values, are protected; providing assistance in restoring archived values as necessary; and installing USGS software, such as National Water Information System (NWIS), in a timely fashion.

2. Assisting users in connecting various hardware, including data-collection devices, to the District computer system.

Other District individuals who assist in surface-water related activities:

\section{Administrative Officer}

The Administrative Officer provides assistance with program development, planning, budgeting, personnel management, procurement, and other administrative topics. Several times during the year, the Administrative Officer meets with the Chief, HSAS to discuss the current program status. The Administrative Officer ensures that all fiscal transactions made by the District are supported by proper documentation. In addition, the Administrative Officer serves as the District personnel specialist advising staff on classification and pay-management matters, personnel regulations and procedures, recruiting sources and appropriate appointment authorities, and pertinent changes in personnel policy that significantly affect surface-water operations.

\section{Safety Officer}

The District Safety Officer consults with the District Chief and supervisory staff to ensure that USGS and WRD safety programs are operational in the District. The Safety Officer identifies job-safety and health hazards, instructs employees on job-safety requirements, reviews accident reports, initiates corrective measures for violations of Occupational Safety and Health Act standards, and directs periodic inspection of all work places, including streamflow-gaging stations. The Safety Officer consults with supervisors to determine safety needs for all employees, prepares District safety plans, and informs supervisors of safety training and equipment needed to safely complete job assignments.

\section{PROGRAM DEVELOPMENT}

The responsibility for program development in the Montana District primarily lies with the District Chief, the Chief, HSAS, and the Chief, Hydrologic Investigations Section, with assistance from various discipline specialists. However, all District personnel are encouraged to promote and participate in program development.

Programs of the Montana District are developed in accordance with priorities identified annually by WRD. The District staff evaluates District program opportunities based on these priorities, on the availability of District resources and expertise, and on cooperator interest and participation.

The Chief, Hydrologic Investigations Section and the District Surface-Water Specialist are responsible for ensuring that all surface-water activities in the Montana District are adequately planned and budgeted They use their specialized knowledge to formulate policies and plans for short- and long-term programs and advise the District senior staff on program development. Examples of items considered during the program development stage are:

1. Identifying present and potential surfacewater problems in Montana.

2. Ascertaining that projects address the following needs, as appropriate:

a. Flow characteristics for water-resource planning, designing, and regulating.

b. Flow information for current water uses.

c. Flow information to define long-term trends.

d. Physical and temporal characteristics of lakes, streams, and wetlands. 
3. Ensuring that projects are within the scope of the USGS mission. Projects outside the WRD area of concern have been identified in WRD Memoranda and generally include the following activities that are provided by other agencies as indicated:

a. Establishment of datum planes (National Oceanic and Atmospheric Administration).

b. Flood forecasting (National Oceanic and Atmospheric Administration).

c. Water management or regulation activities, other than those regulation activities delegated by compact or treaty as a responsibility of WRD.

d. Water supply forecasts (U.S. Department of Agriculture, Natural Resources Conservation Service).

4. Developing goals toward which the District program and projects are directed.

5. Effectively describing program and project proposals to State and other cooperating agency officials.

The program and project planning process is consistent with recommended WRD procedures, cooperative agreements, overall District quality-assurance practices as described by Moreland (1995), and appropriate TWRI's. Program planning and implementation are described in detail in Moreland (1995, p. 12).

\section{QUALITY-ASSURANCE PRACTICES}

The implementation of quality assurance is achieved through practices designed to maintain a consistent and technically sound process for the collection, management, and dissemination of surface-water data. Specific quality-assurance practices have been developed for field and office activities related to stage, streamflow, and sediment data. Descriptions of the various practices and policies are presented in the following sections.

\section{Collection of Stage and Streamflow Data}

Many of society's daily activities, including industry, agriculture, energy production, waste disposal, and recreation, are closely linked to streamflow and water availability; therefore, reliable surface-water records are necessary for planning and resource man- agement. The collection of stage and streamflow data is a primary component in water-resource studies performed by the USGS and other investigators and the ongoing operation of streamflow-gaging stations (for simplicity, referred to in the remainder of this report as gaging stations).

Various water-resources studies require the estimation of flow characteristics based on periodic measurements of discharge at ungaged sites or relations between discharge and various channel-geometry or basin and climatic variables at gaging stations. Discharge measurements at ungaged sites generally are made using the same methods, practices, and policies that are used at gaging stations. Exceptions may be made for investigations where strict adherence to the methods, practices, and policies used at gaging stations would be impractical and where the acceptable error for estimated flow characteristics is much greater than the acceptable error for recorded flow characteristics at gaging stations. All exceptions to discharge-measurement standards used at gaging stations need to be reviewed and approved by the Surface-Water Specialist.

The objective of operating a gaging station is to obtain a continuous record of stage and discharge at the site (Carter and Davidian, 1968, p. 1). A continuous record of stage is obtained by installing instruments that sense and record water-surface elevation of the body of water. Discharge is measured at selected intervals to define or verify the stage-discharge relation and to define the time and magnitude of variations in that relation.

\section{Gage Installation and Maintenance}

Proper installation and maintenance of gaging stations are critical to the quality of surface-water data collected and in the analysis of the data to compute streamflow records. Effective site selection, correct design and construction, and regular maintenance of a gage can make the difference between efficient and accurate determination of records of streamflow and time-consuming, poor estimates of streamflow.

Sites for installation of gaging stations are selected to meet the purpose of each gage. Additionally, sites are selected on the basis of criteria for ideal hydraulic features. Criteria that describe the ideal gaging-station site are listed in Rantz and others (1982, p. 5). These criteria include unchanging natural controls that promote a stable stage-discharge relation, a satisfactory reach for measuring discharge throughout the range of stage, and the means for efficient access to the gage and measuring location (Rantz and others, 1982, 
p. 10). Other aspects considered by District personnel when planning gage-house installations include those discussed in Kennedy (1984, p. 2).

Field Headquarters Chiefs are responsible for selecting sites for new gaging stations with input from cooperating agency officials and the Chief, HSAS. The process of site selection includes meeting with personnel of the cooperating agency to ascertain their needs and determine how the USGS can best assist them in meeting those needs. Preliminary site selection starts with reviewing topographic and county maps and determining the type of gaging equipment needed to collect the data. With the assistance of the Chief, Data Management Unit, computer and paper-file searches are made to determine if previous records have been collected at or near the selected site. USGS personnel, sometimes accompanied by cooperating agency officials, visit the stream reach to determine the best location for the gage. After a potential site has been selected, the following information is recorded: land ownership, access to the proposed gage, gage location, needed equipment, availability of electricity, high- and low-water measuring and control conditions, estimate of stage of the 100-year flood, and any suspected anomalies which might affect the stability of the stage-discharge relation. Video tapes or photography are often used to record conditions at a proposed site. The Field Headquarters Chief is responsible for proper documentation of agreements with property owners and Federal and State permits. The Chief, HSAS is responsible for approving the site selection and design, and inspecting and approving the completed installation. The Field Headquarters Chief is responsible for gage construction, installation of recording instruments, and establishment of gage datum.

Personnel assigned to operate gaging stations must ensure that equipment, gage houses, and cableways are kept in good repair. A program of careful inspection and maintenance of equipment and gage houses promotes the safe collection of reliable and accurate data. Failure to maintain equipment and structures can result in unreliable data and unsafe working conditions. To ensure proper maintenance, the Field Headquarters Chief should visit each assigned station annually, preferably accompanied by the personnel assigned to the station. Recommendations or deficiencies observed at the gaging station and any unsafe conditions are documented on the annual gaging station and cableway safety inspection checklist (fig. 4).

\section{Measurement of Stage}

Many types of instruments are available for measuring the water stage (elevation of the water surface) at gaging stations. The term "gage height" is equivalent to stage and used interchangeably. Gages are identified as nonrecording (Rantz and others, 1982, p. 24) and recording (Rantz and others, 1982, p. 32). Because stage data may be used for various applications, Office of Surface Water (OSW) policy is that surface-water stage record be collected with instruments and procedures that provide sufficient accuracy to support computation of daily mean discharge from the stagedischarge relation (Office of Surface Water memorandum 93.07). In general, a gaging-station criterion for determining daily discharge is an accuracy of $\pm 0.01 \mathrm{ft}$ for stage measurement (Office of Surface Water memorandum 89.08). An explanation of WRD policy on stage-measurement accuracy as it relates to instrumentation is provided in Office of Surface Water memorandum 93.07.

The specific types of instrumentation are selected to address site conditions, meet minimum accuracy requirements, and address special cooperator needs for frequency of sampling or telemetry. Types of water-stage recorders used in the Montana District include Stevens A-35 and A-71 graphic water-stage recorders, Fischer-Porter and Stevens Digital recorders, Stevens electronic data logger, Stevens GS-93 data logger, Design Analysis data loggers, Water-Gage II, and Sutron electronic data loggers.

The Field Headquarters Chief after consulting with the Chief, HSAS is responsible for selecting the type of stage recorder needed at each gaging station. The Field Headquarters Chief ensures that any new equipment has been installed safely and correctly. The person assigned to the gaging station is responsible for the proper operation of gage equipment or replacement, if appropriate. At times, the field personnel may need to obtain instruction or assistance to ensure proper installation or maintenance of equipment.

Accurate stage measurement requires not only accurate instrumentation, but also proper installation and continual monitoring of all system components to ensure the accuracy does not deteriorate with time (Office of Surface Water memorandum 93.07). To ensure that accurate water levels are recorded at the site, "inside" and "outside" water-level readings are obtained independently. The inside water-level readings are not always equal to the outside readings, especially if the gages are not in the same pool at all ranges of stage. At stations equipped with a stilling well, the base or reference gage typically is an instrument installed inside the gage house. Other gages are 

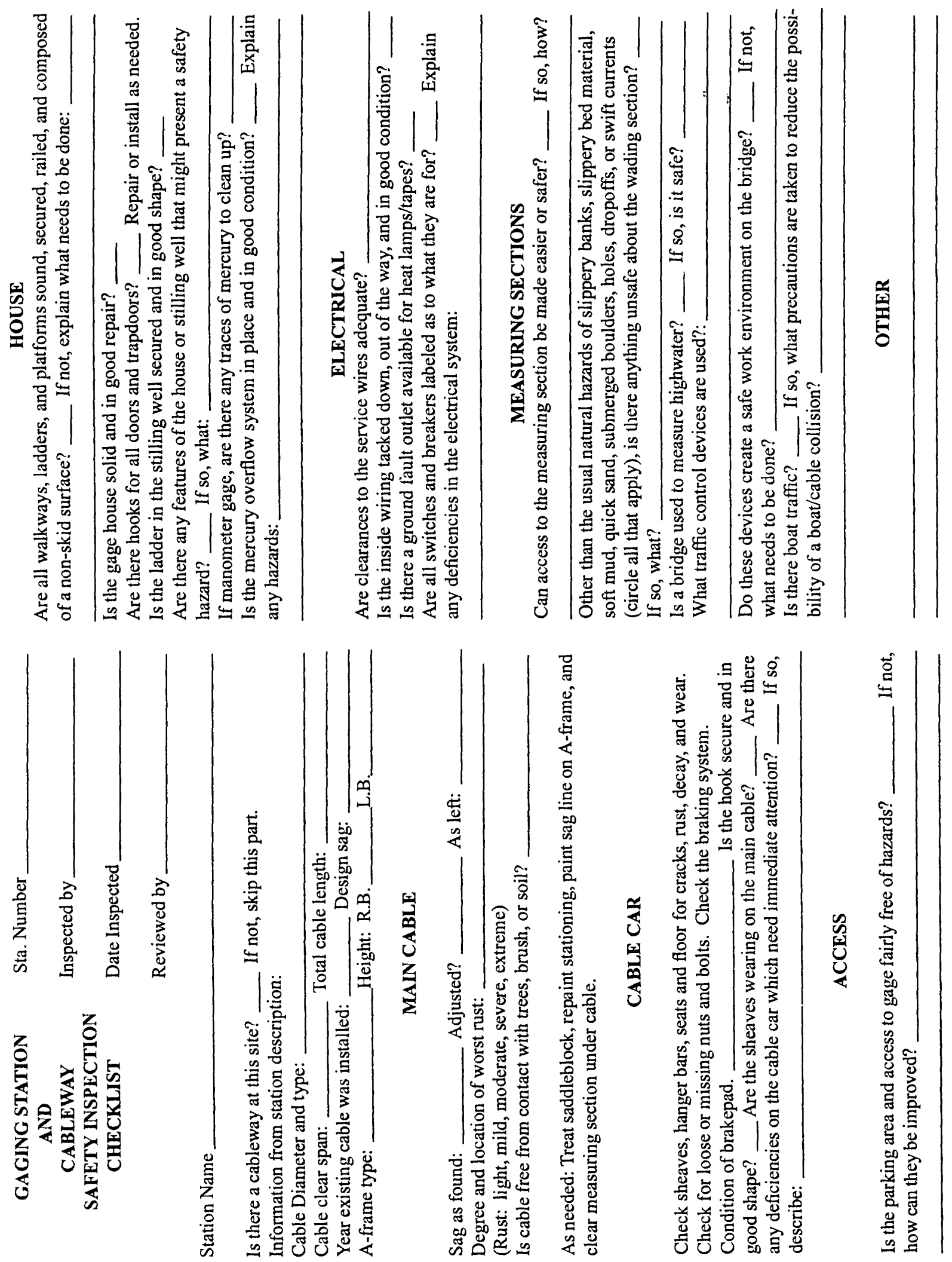

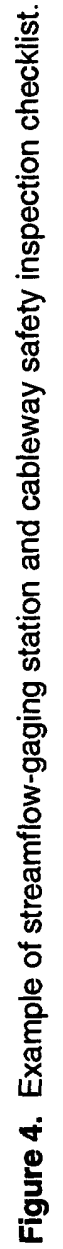




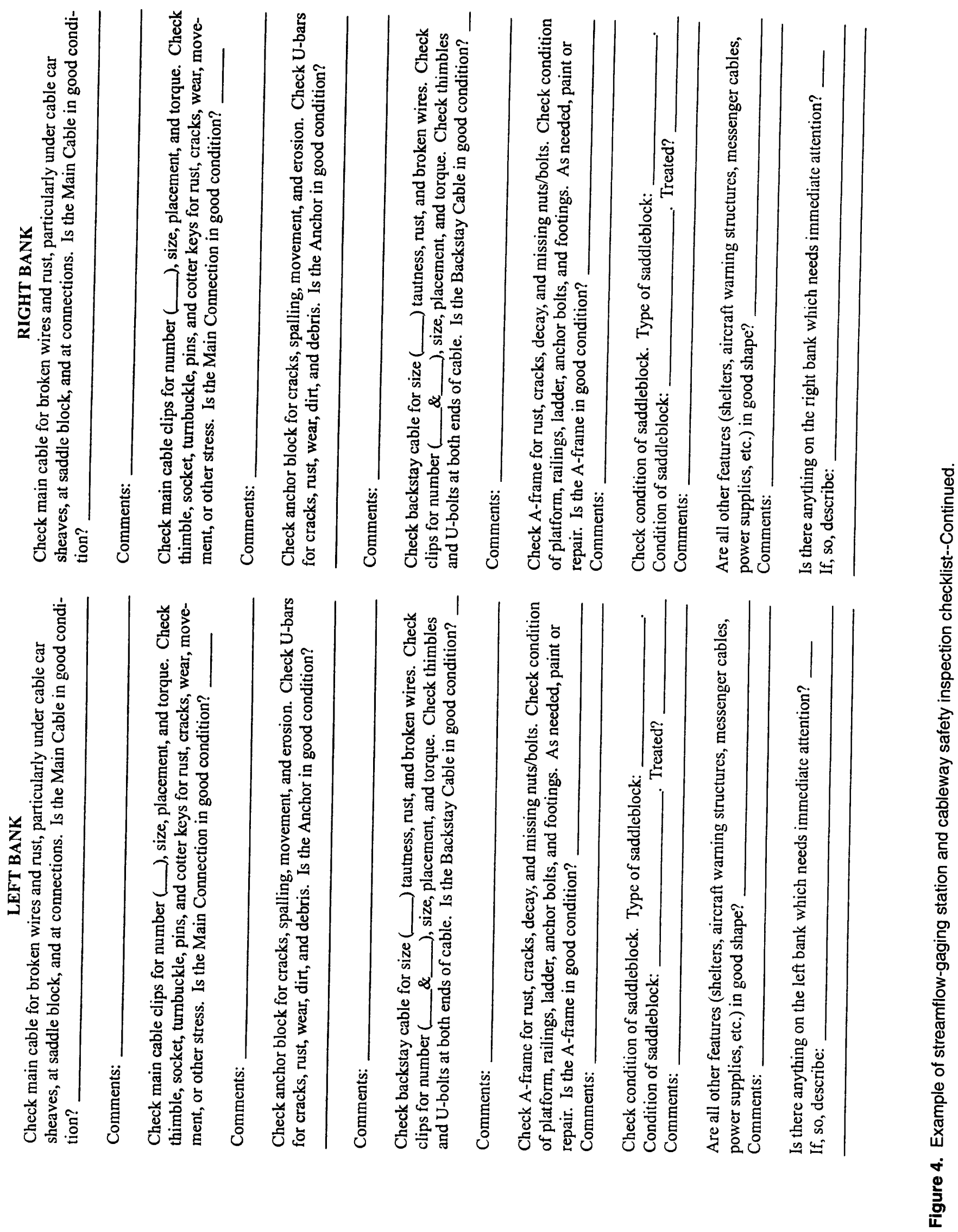


installed outside the gage house to serve as an independent reference to indicate whether or not the intakes are operating properly (Rantz and others, 1982, p. 53 and 64).

Personnel servicing the gage are responsible for comparing inside and outside gage readings during each site visit to determine if the outside water level is being represented correctly by the instrumentation. If a deficiency is identified, the problem is documented on the field note sheet. To prevent buildup of mud or clogging of intakes or orifices, stilling wells and manometers are pumped or purged as needed to ensure an accurate stage reading when compared to an independent outside reference gage. Other regular maintenance activities include: checking battery voltage, inspecting data-collection platforms (DCP's) during each site visit; installing heat lamps and frost floors to reduce the effects of cold temperatures on the gage during the winter; semiannually checking ink in pen reservoirs on analog recorders and running a pen trace to top and bottom of the chart to determine paper skew; and cleaning the gage house, removing brush and debris from around the gage house, outside gages, and cableway, and repainting structures as needed.

Ensuring that gage instrumentation is properly serviced and calibrated is the responsibility of the person assigned to the gaging station. Field personnel should be familiar with and understand manufacturer product manuals and use and care instructions, and applicable TWRI's and WRD memoranda. Ideally, all sensors and recorders should be bench tested prior to installation at the gage. This practice will ensure proper calibration of equipment and may eliminate additional site visits. When instruments are installed at the gage, they should be checked for loose fittings and connections, and improper alignment or orientation.

Sensors and recorders should be calibrated against reference gages and manually operated through a representative range of stage and recording cycles to test their performance. Accurately completed field notes will identify calibration and testing results at the time the data were collected. Field notes are to describe the unmeasured variables that could affect the accuracy or reliability of any determination; indicate any uncertainties or deviations from common experience; and report any information that could affect the use, analysis, or interpretation of the data. When equipment problems are identified, the field person should immediately correct the problem. Each field vehicle should be supplied with adequate tools and spare parts to repair or replace equipment. If a second trip is needed to recalibrate equipment in the gage, it needs to be done as soon as reasonably possible. Individuals who have questions related to the calibration and maintenance of waterstage recorders should contact their Field Headquarters Chief or, in their absence, the Chief, HSAS.

\section{Gage Documents}

District policy specifies that certain documents be placed in each gage house and updated during each visit for the purpose of keeping an onsite record of observations of stage, equipment maintenance, structural maintenance, and other information helpful to field personnel, record reviewers, and cooperating agencies. Documents maintained at each gage house include: (1) the most recent tabular listing of the stagedischarge relation (rating table); (2) a graph of the stage-discharge relation (rating curve) upon which each new measurement is plotted; (3) the most recent station description listing all gages at the site, locations of measurement cross sections, information related to extreme events including the potential for channel storage between the gage and measuring section during flooding, and other information (see the section "Station Descriptions" in this report); (4) a log updated by field personnel during each site visit describing control conditions and listing gage readings, discharge measured, gage-house maintenance performed, and instrument maintenance performed; (5) a calendar; and (6) important contacts and telephone numbers, including the Montana District office number, 406-441-1319.

The person assigned to the gaging station is responsible for exchanging outdated material with updated gage documents as needed. Nonassigned field personnel who visit a gage house and identify a need to update one or more of the documents should notify the Field Headquarters Chief. Individuals having questions about which documents should be kept in a gage house, when the documents should be updated, or appropriate methods of appending logs or plotting measurements should contact either the Field Headquarters Chief or the Chief, HSAS.

\section{Levels}

The various instruments at a gaging station are set to register the elevation of the water surface above a selected level reference elevation called the gage datum. The gage's supporting structure-stilling wells, backings, shelters, bridges, and other structures-tend to settle or rise as a result of earth movement, static or dynamic loads, vibration, or battering by floodwaters and flood-borne ice or debris. Vertical movement of a structure makes the attached gages read too high or too low and, if the errors go undetected, may lead to increased uncertainties in streamflow 
records. Leveling, a procedure by which surveying instruments are used to determine the differences in elevation between points, is used to set the gages and to check them from time to time for vertical movement (Kennedy, 1990, p. 1). Levels are run periodically to all bench marks; reference marks (RM's), reference points, and gages at each gaging station to determine any datum changes (Rantz and others, 1982, p. 545).

This section establishes the frequency and procedures for running levels in the Montana District. Many of the procedures and instructions were obtained from Water-Supply Papers 888 (Corbett and others, 1962) and 2175 (Rantz and others, 1982, p. 545); TWRI's; Levels at Streamflow Gaging Stations (Kennedy, 1990) and Topographic Instructions of the USGS, Leveling, Book 2 (U.S. Geological Survey, 1966); and other WRD training manuals and textbooks on surveying. Hydrologists and hydrologic technicians supervising or reviewing leveling work should check the level notes as soon as practical after they are run to assure that the proper procedures are being followed and that the notes are neat, clear, and concise, and that they conform with these instructions. Detailed instructions for running levels in the Montana District are outlined in Appendix D of the Montana District Surface-Water Manual. Figure 5 shows the forms used by the Montana District to record level notes at gaging stations and crest-stage gages.

\section{Frequency of Levels}

Levels are run at newly installed gaging stations within 1 year after being established. Levels are run to established gaging stations according to the following criteria:

1. At stations with stilling wells, 25 years of record or more, and no evidence of instability, levels are run at 5-10 year intervals.

2. At stations with stilling wells, any period of record, and evidence of instability, levels are run at 3-5 year intervals.

3. At stations where daily wire-weight or staffgage readings are obtained, levels are run yearly.

4. At stations with submersible or non-submersible transducers, levels are run yearly or more often, as needed to maintain the relation of outside water surface to reference readings. For example, if a stable relation is found, a stable outside staff is the reference gage, and outside water surface readings do not vary (within limits) from the reference readings, then the same frequency as for a stilling well site may be used.

5. At crest-stage gages, levels are generally run yearly; however, if a long-term record of stability has been established, a longer interval may be used if approved by the Chief, Hydraulics and Hydrology Unit.

6. Some exceptions to the above five criteria are:
a. Known instability.
b. Unexplained differences between outside and inside gage readings.
c. Vandalism or other damage that requires replacing or resetting gages.
d. Any other reason that casts doubt on the reliability of RM's, gage settings, or the gage datum.
Under these conditions, levels are run as often as needed. If levels are needed, a complete set of levels is always obtained.

As determined by levels, gages are reset when a difference of $\pm 0.02 \mathrm{ft}$ from gage datum is found between water-stage recorder and outside gage. Recomputing field notes, checking rod lengths, or resurveying direct-shot readings where the rod was not used are easy ways to confirm that the level run was accurate. When practical, at least three RM's are established for all gaging stations. At least one of the RM's is to be located away from bridges, cableways, or the gage house foundation. When gages are reset, this fact is recorded by field personnel on the original field note.

\section{Referencing Gage Datum to Sea Level}

If a gaging station is established near an existing bench mark, or if a bench mark is placed near the station after it has been established, the sea-level elevation for "zero" of the gage should be determined. This is done by running levels to determine sea-level elevations of pertinent gage features and water surface at the gage. A conservative estimate is made of the likely minimum elevation that the stream will reach. A suitable elevation near this likely minimum is selected as the gage datum and documented in the station description. This sea-level elevation is assigned a stage of $0.00 \mathrm{ft}$, with all stage measurements thus representing elevation, in feet, above this datum. Any stage reading can then be converted back to sea-level elevation by adding the measured stage to the sea-level elevation of the gage datum. 


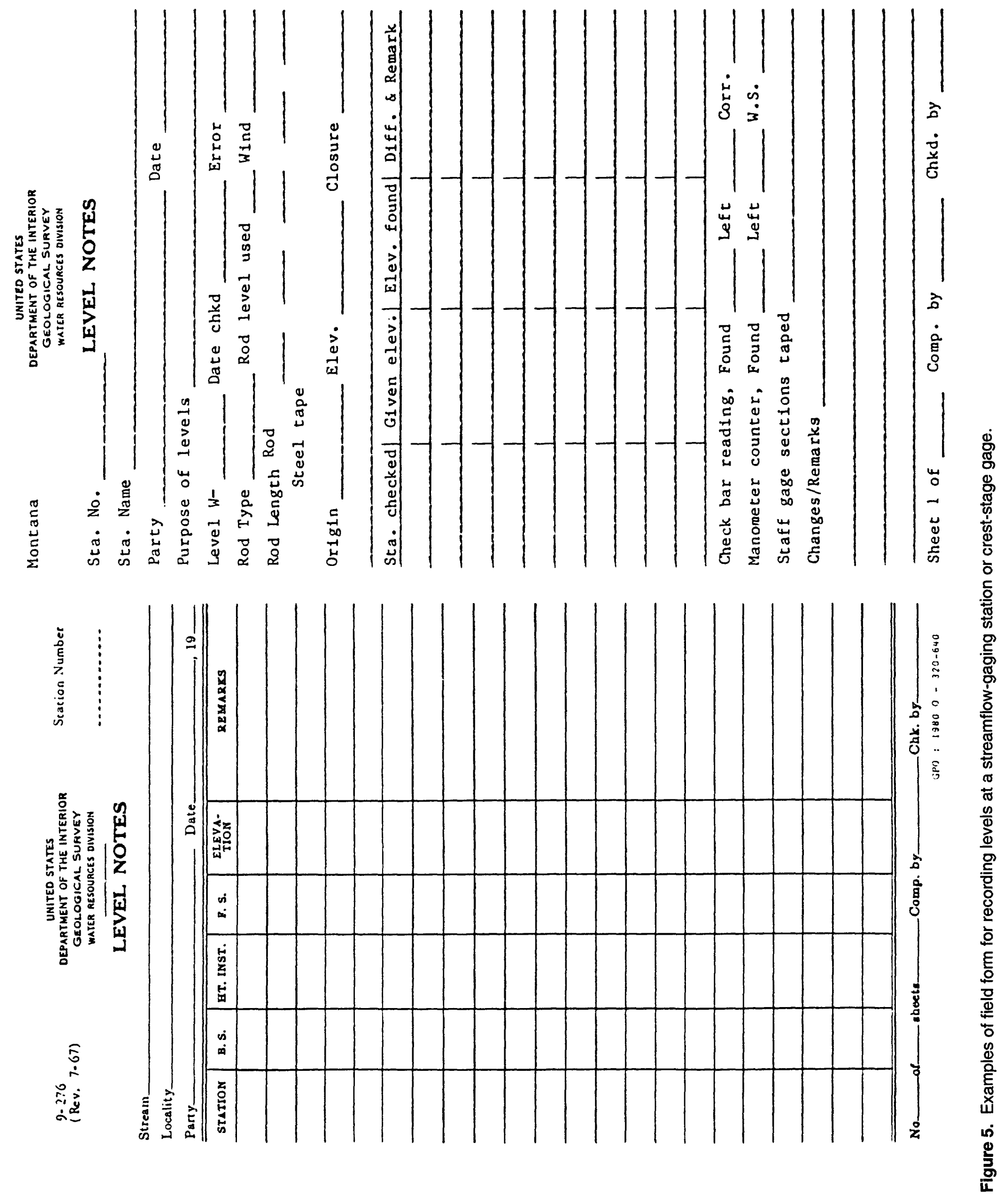


The sea-level elevation of the gage datum will be determined, if possible, for all stations on major streams or for any station within $3 \mathrm{mi}$ of a populated area. The elevation of the bench mark is the elevation as determined from the latest level-net adjustment. The date of that adjustment should be obtained from the agency that established it. Bench marks should be accepted only when their reliability and basis of establishment have been authenticated. Published references to a bench mark used by the USGS in referring river stages to sea level should always give the name of the agency responsible for the bench mark and the date of the level-net adjustment used in determining its elevation.

When the sea-level elevation of the gage datum has been determined, the gage can always be reestablished at its previous datum, even if the RM's have been destroyed. This procedure can be helpful in determining the height above gage datum of a major flood occurring after the gage has been discontinued and when the RM's cannot be located.

\section{Reference (or Base) Gage}

When a gaging station is established, a "reference or base gage" will be designated. All gage heights will usually be referred to this gage. It should be a gage that can be checked by levels and for which datum corrections can be easily determined. Also, it should be easy to correct to datum if found to be incorrect.

Reference gages are usually as follows:

1. For a recording station with a well - inside gage.

2. For a transducer gage - outside gage. However, a counter may be set, by levels, to the water surface at a low stage and at some sites may be the reference gage.

3. Wire-weight gage - check bar and the dial are usually set, by levels, to the water surface at a low stage.

4. Staff gage station - lowest gage.

5. Crest-stage gage - top of lower cap.

If the designated "reference or base gage" is out of operation for some reason and another gage is used temporarily, readings from the latter should be converted to equivalent readings for the reference gage. The procedure for converting is to apply a datum correction (if applicable) by comparative readings, from levels, or a combination of the two.

\section{Level Summary Sheet}

A sheet summarizing results of all levels at gaging stations is maintained as part of the information for each station. Results of levels should be added to the summary sheet after completion. The sheet enables a quick review of all level results and assists in identifying unstable reference gages, RM's, reference points, gage supports, and errors in outside staff gages, wireweight gages, and cantilever gages. The level summary sheet also enables a quick comparison of gage settings, errors found, and corrections applied throughout the period of data collection.

Each Field Headquarters Chief ensures that levels are run at the appropriate frequency and that all field level notes are checked. The level information is entered on the level summary sheet by the individual who computes the annual discharge record. This level summary sheet is stored in the station computation folder and should be reviewed annually.

\section{Site Documentation}

Qualitative and quantitative information describing each gaging station needs to be thoroughly documented. This documentation, in the form of a station description and photographs, provides a permanent record of site characteristics, structures, equipment, instrumentation, elevations, location, and changes in control conditions at each site. Information pertaining to these forms of documentation is discussed in the section of this report entitled "Maintenance of Data Base."

\section{Station Descriptions}

A station description is prepared for each gaging station and becomes part of the permanent record for each station. The station description is written when the first year's records are computed. However, an Advance Station Description form (fig. 6) should be completed soon after the station location is determined and given to the Chief, Data Management Unit. The Advance Station Description is used by the Data Management Unit to assign downstream station number and name, computer header information, and input NWIS data descriptor information. The Field Headquarters Chief is responsible for ensuring that station descriptions are prepared correctly and in a timely manner. Station descriptions are updated as needed, but reviewed annually by the person computing the annual record.

Figure 7 is an example of a station description. If additional information or station identification numbers are needed, inquiries should be made to the Chief, Data Management Unit. Individuals assigned to the gaging station are responsible for keeping station descriptions current. Most descriptions are updated 
Part

Helena District

(station Number)

Advance Station Description

(river basin, in caps)

(station name)

Established

LCCATICN..-

, lat

long

in $1 \frac{1}{4} \quad \frac{3}{4} \quad \frac{3}{4} \mathrm{sec}$

,

NS, $\mathrm{R}$. Exi,

County, Hydrologic Unit on bank,

Civic Map No.

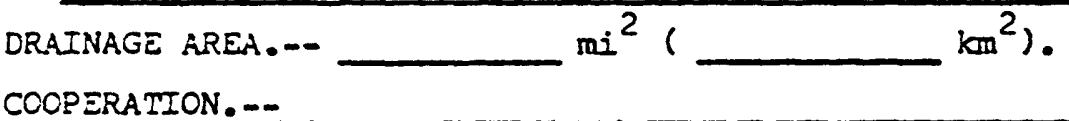

REMARKS - -

CIASSIFICATION.-. (I) $\ldots \ldots-\ldots$

(2)

TUSTIFICATION..-

(Use reverse side for additional infor...ation)

Figure 6. Example of form for Advance Station Description. 
during record computation and are reviewed by each Field Headquarters Chief. Current descriptions are stored in a computer file, easily accessible by interested USGS personnel. Copies of the description are located in the station history folder, field notebook, and gage house.

\section{Photographs}

Field personnel should take photographs showing upstream and downstream views of the site (using the gage house as reference) to document gage-house construction and changes in control conditions, or to supplement various forms of written descriptions. Most field persons have been assigned a camera for recording control or gage-house changes and unusual hydrologic events, such as extensive backwater or high-water flow conditions. The back of each photograph should have the date the photograph was taken, station number and name, gage height and discharge (if streamflow is shown), a brief description of what the photograph shows, and names of any individuals pictured. Slides also should be labeled with the date and station name and number. Photographs for the current year are placed in the computation folder. Older photographs are removed and placed in the station history folder.

The videotaping of gaging stations is encouraged. The Chief, HSAS will check out the District video camera on request. Personal video cameras may be used, but the USGS cannot assume liability for damage to personal equipment. Videotapes can be purchased through regular procurement procedures. The same information included on photographs should be written on the videotape label. Narration while videotaping is encouraged.

\section{Direct Discharge Measurements}

Direct measurements of surface-water discharge are made by any of several methods approved by WRD. The most common is the velocity-area method using standard USGS current meters. "A current-meter measurement is the summation of the products of the subsection areas of the stream cross section and their respective average velocities" (Rantz and others, 1982, p. 80). Procedures used for current-meter measurements are described in Rantz and others (1982, p. 139), Carter and Davidian (1968, p. 7), and Buchanan and Somers (1969, p. 1).

When personnel measure stream discharge, attempts are made to minimize errors by adhering to standard measurement protocols. Sources of errors, identified in Sauer and Meyer (1992), include random errors such as depth errors associated with soft, uneven, or mobile streambeds, and uncertainties in mean velocity associated with vertical-velocity distribution errors and pulsation errors. These errors also include systematic errors, or bias, because of improperly calibrated equipment or improper use of equipment. To detect possible bias, discharge is measured annually, if possible, by someone other than the assigned field person at each gaging station utilizing a separate set of equipment. Also, every 2 or 3 years, field trips are rotated between field personnel. Field areas are assigned by the Field Headquarters Chief. At the gaging station, the individual field person is ultimately responsible for equipment maintenance and performance. The TWRI series, book 8, chapter B2 (Smoot and Novak, 1968) discusses the maintenance of vertical-axis type current meters. The accepted spin tests are those described in the TWRI. The results of the spin tests will be recorded on the "Current Meter Log" as outlined in Office of Surface Water memorandum 89.07. When measuring clear-water streams, the meter will be cleaned and oiled once a day and then spin tested. In turbid streams, the meter will be cleaned and oiled after each measurement.

District policies for measuring discharge using the current-meter method are described below. All these District policies are in accordance with WRD policies. Personnel who have questions about the appropriate procedures for making stage and discharge measurements should contact their Field Headquarters Chief or the Chief, HSAS.

Depth criteria for meter selection.--District personnel select the type of current meter to be used for each discharge measurement on the basis of criteria presented in TWRI's and Water-Supply Papers 888 (Corbett and others, 1962) and 2175 (Rantz and others, 1982). There may be occasions during unusual hydrologic events that require deviations from the use of standard measuring methods. Any deviation from those criteria is noted and the estimate of measurement accuracy is downgraded.

Number of measurement subsections.--"The spacing of observation verticals in the measurement section can affect the accuracy of the measurement" (Rantz and others, 1982, p. 179). WRD criteria are that observations of depth and velocity be made at 25-30 verticals, which are normally necessary so that no more than 5 percent of the total flow is measured in any one subsection. Even under the worst conditions, the discharge computed for each subsection should not exceed 10 percent of the total discharge (Rantz and others, 1982, p. 140). Exceptions to WRD policy are allowed where accuracy would be sacrificed if this 


\section{STATION DESCRIPTION}

\section{Bitterroot River near Darby}

Station number: 12344000

Revised by: S.V. Lynn

$02-09-95$

Reviewed by: R.R.Shields

01-07-97

LOCATION.--Lat $45^{\circ} 58^{\prime} 20^{\prime \prime}$, long $11^{\circ} 08^{\prime} 26^{\prime \prime}$, in SW1/4 SE1/4 NE1/4 sec.36, T.3 N., R.21 W., Ravalli County, Hydrologic Unit 17010205, on left bank $50 \mathrm{ft}$ upstream from bridge on U.S. Highway 93, $0.3 \mathrm{mi}$ downstream from Chaffin Creek, $4.1 \mathrm{mi}$ southeast of Darby, and at river mile 77.2.

\begin{tabular}{|c|l|}
\hline Mile & \multicolumn{1}{|c|}{ Road Log } \\
\hline \hline 0.0 & Post office in Darby. Drive south on U.S. Highway 93 \\
\hline 4.2 & Gage, bridge, and road junctions \\
\hline
\end{tabular}

ESTABLISHMENT.--Recording gage installed August 2, 1939.

DRAINAGE AREA.-- $1,049 \mathrm{mi}^{2}$.

GAGE.--Fischer-Porter digital (15 min cycle) operated by a LaBarge DCP (DCP ID 165512BC, transmission time $0023 \mathrm{hrs}$ GMT) and Stevens A-35 graphic (scale 1:6) recorders driven by a single float in a wooden shelter over concrete well. A Servo manometer is also present for use during low flow winter periods. Power available to run heat, lights, and power converters. Inside gage is a standard USGS electric tape gage. Auxillary inside gage consists of enameled gage sections $0.00-10.14 \mathrm{ft}$ mounted on plank bolted to downstream side of well. Outside gage is a wire-weight gage and cantilever attached to the upstream side of the gage house. Flushing system connected to the two 2 -in. intakes is of the gatevalve type, with hand pump available.

Pertinent elevations are as follows:

\begin{tabular}{|l|c|c|}
\hline \multicolumn{1}{|c|}{ Gage datum } & $\mathbf{f t}$ & NGVD \\
\hline \hline Bottom of well & 0.4 & $3,942.54$ \\
\hline Top of lower intake in well & 1.11 & $3,943.25$ \\
\hline Top of lower intake in stream (24 ft) & -0.09 & $3,942.05$ \\
\hline Top of upper intake in well & 2.01 & $3,944.15$ \\
\hline Top of upper intake in stream (14 ft) & 1.61 & $3,943.75$ \\
\hline Floor level & 11.6 & $3,953.7$ \\
\hline Top of cabinet & 14.5 & $3,956.6$ \\
\hline Electric tape index & 14.63 & $3,956.77$ \\
\hline
\end{tabular}

Datum of gage is $3,942.14 \mathrm{ft}$ above sea level.

HISTORY.--Apr. 4, 1937 to Aug. 2, 1939, wire-weight gage on downstream side of former highway bridge $50 \mathrm{ft}$ upstream. Prior to Oct. 1, 1987, water-stage recorder at present site at datum $1.00 \mathrm{ft}$ higher.

REFERENCE MARKS.--RM Nos. 1 \& 3 and BM Q 477 were destroyed when the new highway bridge was constructed.

RM No. 4 is top of steel fence post, painted yellow, in fence line $29 \mathrm{ft}$ shoreward and $10 \mathrm{ft}$ upstream from gage. Elevation, $13.71 \mathrm{ft}$ above gage datum, $3,955.85 \mathrm{ft}$ above sea level.

Figure 7. Example of station description. 
RM No. 5 is top of anchor bolt on downstream side of left bank A-frame pedestal. Elevation, 14.22 $\mathrm{ft}$ above gage datum, $3,956.36 \mathrm{ft}$ above sea level.

RM No. 6 is top of lag bolt in power pole $50 \mathrm{ft}$ shoreward and $10 \mathrm{ft}$ upstream at end of fence line. Elevation, $17.00 \mathrm{ft}$ above gage datum, $3,959.00 \mathrm{ft}$ above sea level.

CHANNEL AND CONTROL.--The low-water control is a rock and gravel riffle about $500 \mathrm{ft}$ downstream and some shifting may be caused by high water. Channel control at medium and high stages, flow should be contained within the banks. New highway bridge with center pier constructed during the summer and fall of 1986 about $50 \mathrm{ft}$ downstream from gage will cause some channel constriction at high stages. There is some brush and trees along the banks that may have some effect at medium and high stages. The streambed is rocky and should be subject to very little change. The channel is straight for $200 \mathrm{ft}$ upstream and $300 \mathrm{ft}$ downstream from the gage.

DISCHARGE MEASUREMENTS.--Low-flow wading measurements are made between the gage and riffle $500 \mathrm{ft}$ downstream. Maximum wading stage is about $1.2 \mathrm{ft}$, gage datum. Medium and high flows are measured from cableway located $20 \mathrm{ft}$ upstream from bridge. Aluminum sitdown car equipped to type "A" or "B" reels is at left bank. Cable is 7/8 in. galvanized IWRC cable with clear span of $232 \mathrm{ft}$, supported on each bank by steel "A" frames, left bank $12 \mathrm{ft}$ high and right bank $14 \mathrm{ft}$ high. "A" frames are bolted to 8 -in. channel iron sill plates set on concrete pedestals with concrete gravity anchors on each bank. Cable marked at $5 \mathrm{ft}$ intervals with initial point and erection sag of $2 \mathrm{ft}$ marked on right bank "A" frame. New steel "A" frames were erected December 1972; existing concrete pedestals, anchorages and cable were not replaced. Current cable was installed August 1995.

FLOODS.--Maximum discharge, $11,500 \mathrm{ft}^{3} / \mathrm{s}$ May 9,1947 , gage height, $8.18 \mathrm{ft}$. Maximum gage height 8.42 $\mathrm{ft}$, June 17, 1974, backwater from log jam.

POINT OF ZERO FLOW.--About -0.1 ft gage datum, September 1987.

WINTER FLOW.--Affected by ice for short periods during very cold periods.

REGULATION AND DIVERSION.--Practically complete regulation of flow of West Fork of Bitterroot River by Painted Rocks Lake since 1940, no regulation on East Fork. Diversions for irrigation of about 5,000 acres upstream from station. Ditch bypassing station irrigates about 500 acres downstream.

ACCURACY.--Good except during periods of ice effect, which are poor.

COOPERATION.--Montana Department of Natural Resources and Conservation.

SKETCH.--See quadrangle.

PHOTOGRAPHS.--On file in Helena field office.

QUADRANGLE.--Burnt Ridge, MT, 7.5 min, 1964.

Figure 7. Example of station description--Continued. 
number of verticals were maintained, such as for measurements during rapidly changing stage (Rantz and others, 1982, p. 174). Fewer verticals than are ideal are sometimes used for measuring very narrow streams (about 12- $\mathrm{ft}$ wide when a Price AA meter is used and about 5-ft wide when a Price pygmy meter is used). Measurement of discharge is essentially a sampling of depths and velocities, and the reliability of obtaining an accurate measurement of flow typically decreases markedly when the number of verticals is less than about 25 .

District policy follows WRD and OSW techniques and guidelines when discharge is measured by other direct methods of measurement, such as the use of weirs, flumes, and volumetric methods. Portable weir plates and flumes are used by District personnel during extreme low-flow conditions to measure discharge. These portable devices are applied according to methods described in Buchanan and Somers (1969, p. 57), Rantz and others (1982, p. 263), and Kilpatrick and Schneider (1983).

Computation of mean gage height.--District personnel use procedures presented in Rantz and others (1982,p. 170) for the computation of mean gage height during a discharge measurement. Mean gage height of the discharge measurement and the instantaneous discharge measured are used in developing the stage-discharge relation (rating) at a gaging station.

Check discharge measurements.--A second discharge measurement is made to check a discharge measurement when the first measured value significantly departs from a defined segment of the rating curve. If the discharge measurement departs from either a defined segment of the rating curve or the trend of recent measurements by 10 percent or more, the field person is normally expected to make a "check" discharge measurement. When making a check measurement, the possibility of systematic error is reduced by changing the measurement conditions as much as possible. The meter and stopwatch are changed, although the same stopwatch may be used if checked against the movement of the second hand of a standard watch. If the measurements are being made from a bridge, boat, or cableway, the measurement verticals are located between those originally used. If the measurement is being made by wading, a new measurement section may be selected or the original section may be used with different verticals. If the check measurement is within 5 percent of the rating curve or recent trend of departure, the first discharge measurement is entered in the data base but will be given no consideration in the rating analysis. If the check measurement is within 5 percent of the first discharge measurement, the two measurements are considered to be reliable evidence of a new shift in the stage-discharge relation. If the check measurement fails to agree with any previous measurements, a second check measurement is made and the most consistent two of the three measurements are used for rating analysis. The need for a second check measurement is rare, but may occur. Thus, a single discharge measurement and accompanying check measurement, even if unsupported by future measurements, may mark a short period of shifting control.

The person who analyzes the rating is responsible for examining possible causes for the short-lived shift. A short-lived shift often can result from either fill or scour of the streambed. Shifting of the bed may begin on a preceding stream rise and end on the recession or on a following stream rise (Rantz and others, 1982, p. 346347).

Corrections for channel storage.--Corrections for channel storage applied to measured discharges made some significant distance from the gage during a change in stage is discussed in Rantz and others (1982, p. 177) and in Office of Surface Water memorandum 92.09 .

\section{Field Notes}

The documentation of hydrologic conditions and of the operation of recording equipment is a very important component for assuring the accuracy of measured and collected data. Field measurements and observations are recorded in accepted engineering format and become a permanent record. Notes must be legible and unambiguous. All information is recorded as obtained and never left to be documented from memory. To ensure that clear, thorough, and systematic notes are made by personnel, field measurements and observations are recorded on standard forms and include the following information:

1. Name of stream and location identified by station name and number or by the latitude and longitude of a miscellaneous site;

2. Date, party, type of meter suspension, meter number, and spin test;

3. Time of measurement using military (24hour) time;

4. Bank of stream used as the starting point;

5. Streamflow, cross-section, control, and weather conditions;

6. Gage heights and corresponding times;

7. Water and air temperatures;

8. Other information affecting the accuracy of the discharge measurement and the stagedischarge relation. 
Original observations, once written on the note sheet, are not erased. Original data are corrected by crossing out the incorrect value then writing in the correct value. Changes from original data are initialled by the person making the change. Some examples of original data on a discharge-measurement note sheet include vertical stationing, gage readings, and depth determinations. Examples of information on a discharge-measurement note sheet that is computed from original data include the mean gage height and total discharge listed on the front sheet of the discharge measurement note. Computed data can be erased for the purpose of correction.

District policy is to have all discharge measurements calculated in their entirety before field personnel leave the site, unless exceptional circumstances of safety or other priorities warrant departure from the policy.

Information about miscellaneous surface-water data-collection sites are documented on the District's station header information form the first time a site is measured (fig. 8). This form can be obtained from the Field Headquarters Chief or Chief, Data Management Unit. A completed copy of this form and all additional miscellaneous measurement data should be given to Chief, Data Management Unit soon after the site is established. If the data are available, all miscellaneous notes are required to include the same information as those for a regular gaging station. At a new miscellaneous site which may be visited often, a temporary RM with an arbitrary elevation (for example, $99.99 \mathrm{ft}$ ) needs to be established. No gage-height reading is required where defining a stage-discharge relation is not a measurement object.

Field note sheets need to be reviewed after each field trip by the field-note checker and annually as part of a surface-water records review by the Field Headquarters Chief. Deficiencies found in the content, accuracy, clarity, or thoroughness of field notes are identified and communicated to the collector of the data by the Field Headquarters Chief either in writing or orally.

\section{Acceptable Equipment}

Equipment used by the Montana District for direct measurement of surface-water discharge has been sanctioned by the WRD through field use and testing at hydraulics laboratories. Acceptable equipment for measuring discharge includes, but is not limited to, current meters, timers, wading rods, bridge cranes, and tag lines (Rantz and others, 1982, p. 82; Smoot and Novak, 1968). Although an official list of acceptable equipment is not available, Buchanan and Somers
(1969), Carter and Davidian (1968), and Edwards and Glysson (1988) discuss the equipment used by the USGS.

The meters most commonly used by District personnel for measuring surface-water discharge are the Price AA mechanical current meter, the Price pygmy mechanical current meter, and the Marsh-McBirney Model 2000 electromagnetic current meter. Methods used by District personnel for inspecting, repairing, and cleaning these meters are described in Smoot and Novak (1968, p. 9), Rantz and others (1982, p. 93), Buchanan and Somers (1969, p. 7), and the Flo-Mate Manual (Marsh-McBirney, Inc., 1994).

District policy requires spin testing of mechanical current meters prior to each field trip. Spin-test results are documented on the "current meter log" that is maintained for each instrument. This log is maintained by the field person and used by other personnel during equipment repair. This log becomes part of the archived record of WRD (Office of Surface Water memorandum 89.07). Meters are repaired in the field when deficiencies are identified through the spin test or inspection. Damaged current meters are not to be used under any circumstance; spare meters carried as part of routine field supplies should be used. If deficiencies are observed and the meter cannot be repaired in the District, the meter, together with written communication, is sent to the Hydrologic Instrumentation Facility (HIF) in Bay St. Louis, Miss., for performance evaluation. If necessary, repairs and meter enhancements are made by HIF before the meter is used in the field.

In addition to the spin tests performed prior to field trips, field personnel are required to inspect the meter before and after each measurement to ensure that the meter is in good condition, that the cups spin freely, and the cups do not stop abruptly. Results of these inspections are noted at the appropriate location on the field-note sheet.

\section{Alternative Equipment}

Development of new technology sometimes involves the direct measurement of surface-water discharge with alternative equipment that has not been fully accepted by WRD. To demonstrate the quality of surface-water data collected with alternative equipment, thorough documentation of procedures and observations must be maintained.

\section{Indirect Discharge Measurements}

In many situations, especially during floods, measurement of peak discharge by current meter is impossible or impractical. Personnel may not 


\section{STATION HEADER INFORMATION}

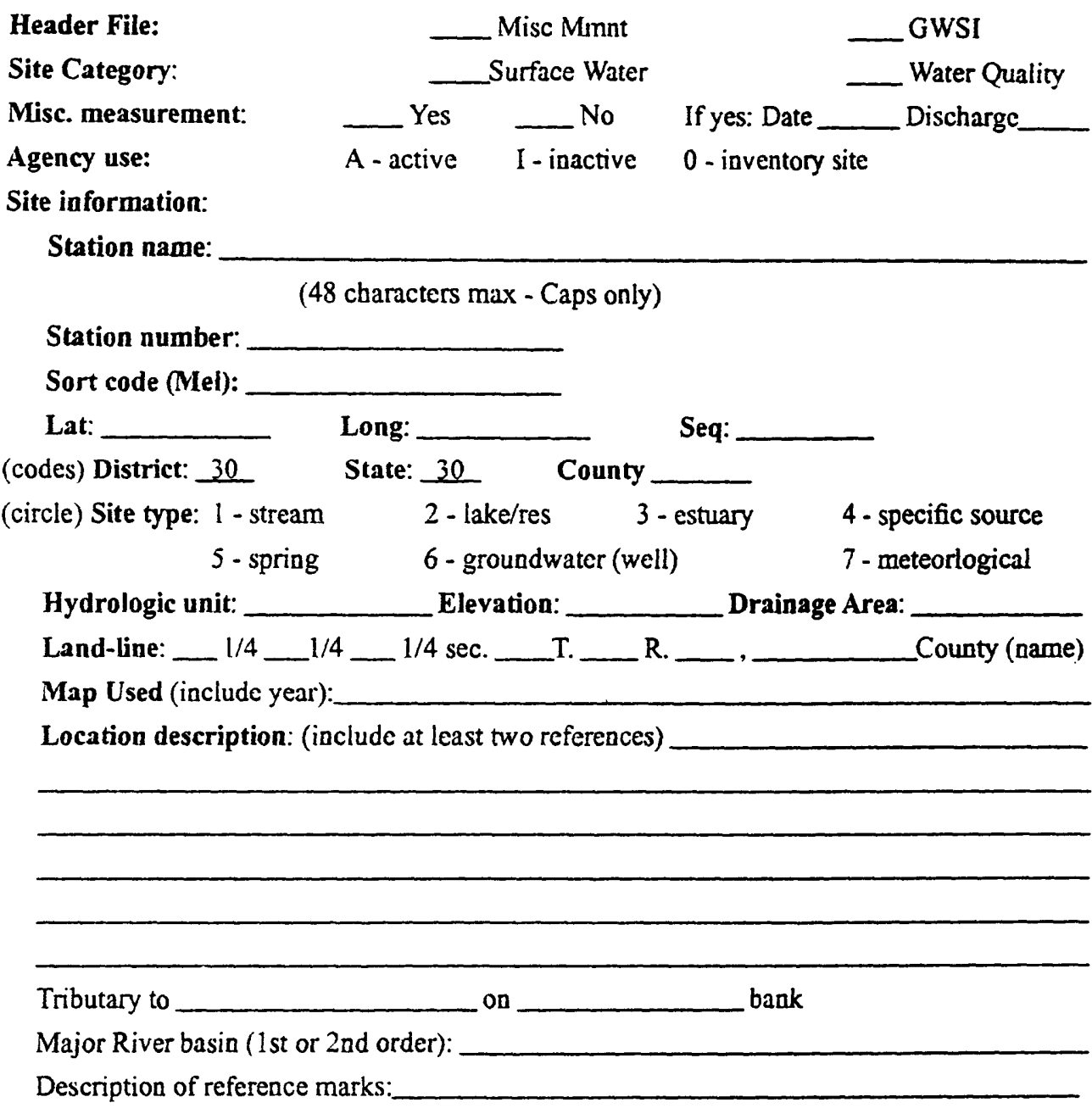

Purpose of measurement or sample:

Prepared by : Date:

Figure 8. Example of form for recording station header information. 
have sufficient warning to reach the site to make a direct measurement, or physical access to the site during the event may not be feasible.

A peak discharge determined by indirect methods is in many situations the best available means of defining the upper portion of the stage-discharge relation at a site. Because extrapolation of the stage-discharge relation beyond twice the measured discharge at a gaging station is undesirable and possibly unreliable, discharge measurements made by indirect methods during periods of high flow are important data (Rantz and others, 1982, p. 334).

The District follows data-collection and computation procedures presented in Benson and Dalrymple (1967). That report includes policies and procedures related to site selection, field survey, identification of high-water marks, selection of roughness coefficients, computations, and the written summary. General guidelines that are followed by the District when making indirect measurements include those discussed in Office of Surface Water memoranda 92.10 and 92.11 .

In addition to the general procedures presented in Benson and Dalrymple (1967), the District follows guidelines presented in other reports that describe specific types of indirect measurements suited to specific types of flow conditions. The most commonly used indirect-discharge method, the slope-area method, is described in Barnes (1967) and Dalrymple and Benson (1967). The computer program for computations of peak discharge with the slope-area method (SAC) is described in Fulford (1994). Procedures for the determination of peak discharge through culverts is described in Bodhaine (1982), and the computer program for computations of peak discharge at culverts (CAP) is described in Fulford (1995). The width-contraction method, commonly used where flow is constricted by a bridge, is described in Matthai (1967). Computation of peak discharge at dams and weirs, including highway and railroad embankments, is described in Hulsing (1967).

The Surface-Water Specialist is responsible for reviewing indirect measurements and ensuring that procedures, documentation, and results are valid. All indirect measurements used for rating-curve development are reviewed about every 3 years, along with data from regular surface-water stations, when District surface-water programs are reviewed by selected personnel from Office of Surface Water, Central Region, and other Districts. The reviewers verify procedures and documentation used in computing indirect measurements, and the review comments become part of the permanent record. Measurements that are questionable and difficult to assess may be reviewed by specialists outside the District. The Surface-Water Specialist is responsible for ensuring that any required revisions identified by the outside reviewers are corrected.

The Field Headquarters Chief is responsible for determining when and where indirect measurements are required. The District policy is that indirect measurements generally are made at sites where direct measurements are unattainable because of hazardous high-water measuring conditions. At gaging stations where a well-defined upper-end rating curve has been developed, unmeasured peak open-water gage heights may be plotted and the rating extended. The Field Headquarters Chief should be consulted when a rating needs to be extended.

The person visiting the station is responsible for identifying and flagging high-water marks. Because the quality and clarity of high-water marks are best soon after an event, field personnel are required to have nails, survey stakes, flagging, and spray paint in their field vehicles. Because selection of a suitable reach of channel is extremely important in making an indirect measurement, the stream reach for indirect measurements at specified ranges of stage has been preselected at some gaging-station sites, and that information has been included in the station description.

After each indirect measurement is computed, the graphs, field notes and data, plotted profiles, maps, calculations or computer output, and written analysis of the measurement are checked by personnel in the unit or office collecting the data. The data and computations are then sent to the Surface-Water Specialist for review and permanent storage in the Hydraulics and Hydrology Unit.

The District is responsible for maintaining the accuracy of the peak-flow data files including computer data-base files (Office of Surface Water memorandum 92.10). The Surface-Water Specialist is responsible for ensuring that indirect-measurement results are entered into the peak-flow files. For further discussion on the update and review of the peak-flow files, refer to the section titled "Management of Data Base."

\section{Crest-Stage Gages}

Crest-stage gages (CSG) are used to record peak surface-water elevations. The peak stages recorded by CSG's may be used to verify continuous recorded data or to determine the water-surface profile at selected sites. The OSW requires comparable QA procedures used at continuous-record gaging stations to be used at CSG's (Office of Surface Water memorandum 88.07). 
The operation of CSG's is part of the District's surface-water activities. Procedures to be followed in the operation of CSG's are presented in Rantz and others (1982, p. 9, 77-78). One or more CSG's are maintained at each selected site where peak water-surface elevations are collected. Upstream and downstream gages are maintained at culverts or other structures where water-surface elevations are required to compute discharge through the structure and to determine the water-surface profile.

At new CSG's the stage-discharge relation is developed on the basis of direct and indirect discharge measurements, and, for locations where direct measurements may be difficult to obtain, water-surface profile computations using the standard step-backwater method (Davidian, 1984; Shearman, 1990). Subsequent direct and indirect discharge measurements are made to verify the stage-discharge relation. Levels are run to the CSG's about every 3 years or as soon as possible after a gage has been disturbed. When peaks are extremely high, a high-water mark is located and flagged along the streambank to confirm the CSG's recorded elevation. The location of the high-water mark is to be documented and the elevation of the highwater mark determined by levels.

Field observations are entered on a Crest-Stage Gage Inspection note sheet (fig. 9). All field notes are required to include the station name and identification number, initials and last name of inspecting personnel, date, time of observation, gage height, measured discharge, and a sketched location of high-water marks.

The Field Headquarters Chief is responsible for ensuring that correct data-collection procedures are used by personnel. This responsibility includes examining all note sheets of personnel in their first 3 years of experience, or when field personnel encounter unusual conditions. Policies and procedures for computation of peak discharges at CSG's and associated documentation are presented in the section entitled "Processing and Analysis of Stage and Streamflow Data" of this report.

\section{Artificial Controls}

Artificial controls, including broad-crested weirs, thin-plate weirs, and flumes, may be built in stream channels to simplify the procedure of obtaining accurate low-flow measurements of streamflow (Rantz and others, 1982, p. 12). Such structures serve to stabilize and constrict the channel at a section, reducing the variability of the stage-discharge relation.

Artificial controls are used at some gaging stations maintained by this District. Where artificial con- trols are installed, the District policy is that the stagedischarge relations be verified by direct measurements. Portable weir plates and flumes are used by District personnel during extreme low-flow conditions to measure discharge. These portable devices are applied according to methods described in Buchanan and Somers (1969, p. 57) and Rantz and others (1982, p. 263).

The Field Headquarters Chief is responsible for ensuring the correct selection and installation of artificial controls. The criteria used for the selection of an artificial control include cost, channel characteristics, flow conditions, and range of discharge (Carter and Davidian, 1968, p. 3; Rantz and others, 1982, p. 15 and 348; and Kilpatrick and Schneider, 1983, p. 2 and 44).

When artificial controls are field inspected, information pertaining to conditions of the control is written on the discharge measurement note sheet to assist in the analysis of the surface-water data. These notes include such information as the stability of the control structure and stability of the streambed immediately upstream from the control. Regular maintenance at artificial controls includes running levels to control structures and cleaning the approach section. When problems are encountered by field personnel, these problems should be documented and brought to the attention of the Field Headquarters Chief or Chief, HSAS.

\section{Flood Conditions}

Flood conditions present unusual problems. These problems can include difficulties in gaining access to a gaging site because roads and bridges are flooded, closed, or destroyed. Debris in the streamflow can damage equipment and present safety risks to personnel collecting the data. Rapidly changing stage or conditions requiring measurements to be made at locations some distance away from the gage can create problems in associating a gage height with a measured discharge.

The District maintains a flood plan so that highpriority surface-water data associated with flooding are collected correctly and as promptly as possible. The flood plan describes reporting procedures, fieldactivity priorities, and responsibilities before, during, and after a flood. The flood plan serves as a central reference for emergency communications, telephone numbers for key District personnel, and codes for accessing streamflow gages equipped with telemetry.

The Flood Specialist is responsible for ensuring that the flood plan includes all appropriate information, including updated information. The flood plan is reviewed annually by the Chief, HSAS. A copy of the 


\section{CREST-STAGE GAGE INSPECTION \\ State of Montana - U. S. Geological Survey \\ Cooperative Inveatigation:}

Station Name

Jate.

Party.

Stage today

Time

a.m.

Discharge measured.

Cork Lines:

ITpstream Gage Downstreain Gage Probable Date

1.

2.

3.

4.

$\begin{array}{lccc}\text { Was the stick cleaned? } & \text { Yes } & \text { No } & \\ \text { Was the cork inspected? } & \text { Yes } & \text { No } & \\ \text { Were the intake holes clean? } & \text { Yes } & \text { No } & \\ \text { If not, were they cleaned? } & \text { Yes } & \text { No } & \end{array}$

Condition of gage

Were highwater marks flagged?

(Sketch location on reverse side.)

Were levels obtained?

Control conditions.

Remarks..

Gage height of zero flow.

Figure 9. Example of form for recording crest-stage gage information. 
flood plan is provided to each Field Headquarters, with selected information given to all field personnel. The Flood Specialist ensures that individuals who receive a copy of the plan understand the content of the flood plan.

During a flood, the Flood Specialist and Chief, HSAS coordinate surface-water data-collection activities. Personnel not already in the field should contact the Flood Specialist or Field Headquarters Chief and be ready for assignment. Personnel already in the field should contact the Flood Specialist at least each morning to provide discharge-measurement data and information on local conditions. The Flood Specialist may be able to supply the following information to field personnel: estimates of flood-crest gage heights and times, description of area affected by flooding, current center of storm and storm track, precipitation amounts, road closures, and the location of other field personnel. Personnel who arrive at a gaging station during high water are responsible for (1) their personal safety, (2) ensuring that all station equipment and measuring devices are safe and located above expected high-water crest, (3) determining stage, (4) measuring discharge, and (5) telephoning results to the Flood Specialist, Field Headquarters Chief, or Chief, HSAS. District personnel apply methods discussed in Rantz and others (1982, p. 60) for determining peak stage at gaging stations.

District personnel follow policies and procedures stated in several publications and memoranda when collecting surface-water data during floods. Techniques for current-meter measurements of flood flow are presented in Rantz and others (1982, p. 159170). Procedures for identifying high-water marks for indirect discharge measurements are presented in Benson and Dalrymple (1967, p. 11). When discharge measurements are made a distance from the gaging station during a changing stage, adjustments are applied to make measured discharge hydraulically comparable with recorded gage height as described in Office of Surface Water memorandum 92.09 and in Buchanan and Somers (1969, p. 54). When measuring some distance from the gaging station, the District has a policy of establishing temporary reference marks for noting the rate of stage change.

The Chief, HSAS is responsible for reviewing District activities related to floods. This review includes seeing that guidelines and priorities identified in the flood plan are followed and that the guidelines appropriately address the District's ability to obtain flood data in a safe and thorough manner. When deficiencies are identified, they are communicated to field personnel in oral or written form. All personnel who have questions about particular policies or procedures related to flood activities, or who recognize the need for further training in any aspect of flood-data collection, are responsible for communicating their concerns to their Field Headquarters Chief.

\section{Low-Flow Conditions}

Streamflow conditions encountered during periods of low flow are typically much different from those encountered during periods of medium and high flow. Low-flow discharge is measured to determine the lower segment of the stage-discharge relation for gaging stations and to identify gains or losses of flow between the channel and ground-water system at selected locations for special projects. Additionally, low flow is measured to establish a relation in low-flow characteristics between nearby basins so that flows can be estimated from the basin having more data (Office of Surface Water memorandum 85.17).

In many situations, low flows are associated with factors that reduce the accuracy of the discharge measurement. These factors include (1) shallow depth, (2) algal growth that impedes the free movement of current-meter buckets, (3) non-uniform flow conditions, and (4) difficulty in measuring the flow in narrow spaces between rocks and cobbles. When natural conditions are considered by field personnel to be undependable for purposes of discharge measurement, the cross section is physically improved for measurement by removing debris or large cobbles, constructing dikes to reduce the amount of nonflowing water, or other similar efforts (Buchanan and Somers, 1969, p. 39). After modification of the cross section, the flow is allowed to stabilize before the discharge measurement is begun. Any channel modification should be noted on the discharge measurement note and/or analog strip chart to ensure that gage height readings before and after the measurement are the same. District policy requires that gage height corresponding to zero flow be determined annually by field personnel for all wadable stations. Gage height of zero flow generally is determined by surveying the elevation, referenced to gage datum, of the lowest point of the control.

The Field Headquarters Chief is responsible for ensuring that District personnel use appropriate equipment and procedures during periods of low flow. As part of this responsibility, the Field Headquarters Chief will review all low-flow-related data. The Chief, HSAS is responsible for training District personnel about data collection during periods of low flow. 


\section{Cold-Weather Conditions}

Surface-water activities in this District include measuring stream discharge during cold weather. Cold temperatures, wind, snow, and ice can hinder data collection and can be dangerous to field personnel. Additional procedures are necessary to ensure employee safety when collecting streamflow data during periods of cold weather.

Where the stream at the gaging station is affected by ice, discharge measurements made during complete or partial ice cover are useful for analysis and determination of flow during periods of ice-affected stage record. District personnel need to follow procedures for measuring discharge under ice cover as described in Buchanan and Somers (1969, p. 42), which includes procedures for measuring discharge by wading and from cableways and bridges when debris and ice are in the stream. District personnel also are to follow procedures for collecting winter streamflow data as presented in Rantz and others (1982, p. 124-129). Additionally, Office of Surface Water memorandum 84.05 provides guidelines on equipment for measuring flow under ice.

The equipment presently preferred by OSW for measuring discharge during slush-free conditions under ice cover is a Price AA current meter built with a Water Survey of Canada (WSC) winter-style yoke and a conventional metal-cup rotor. The pygmy meter also may be used for all depths and velocities (Office of Surface Water memorandum 84.05). Where slush ice is present, the metering equipment preferred by OSW has a WSC winter-style yoke with a polymer rotor (Office of Surface Water memorandum 88.18). Although polymer rotors are not to be used during all other conditions (Office of Surface Water memorandum 90.01), the superior ability of the polymer rotor to shed slush ice and retard freezing in ice-covered streams is considered to be more important than the turbulent-flow-related inaccuracies associated with the rotor (Office of Surface Water memorandum 92.04). The OSW also considers the regular Price AA meters with conventional metal-bucket rotors to be acceptable for use in slush-free conditions if holes larger than those required by the WSC winter-style yoke can be cut through the ice (Office of Surface Water memorandum 92.04).

The Fraiser vane ice meter also may be used under ice cover. The vanes do not become filled with slush ice as the cups of the Price AA meter often do. Other advantages of the vane ice meter are the meter will fit in the hole made by the ice drill, the yoke and ice rod can also serve as an ice-measuring stick, and the contact chamber of the vane meter can be rotated to any position.

The velocity distribution under ice cover is similar to that in a pipe, where lower velocities occur near the underside of the ice as well as near the streambed. The conventional $0.2-$ and 0.8 -depth positioning method is recommended for effective depths of $2.5 \mathrm{ft}$ or greater and the 0.6-depth positioning method is recommended for effective depths less than $2.5 \mathrm{ft}$. Ratios of point velocities at various depths need to be defined when ice measurements are made to determine whether any coefficients are necessary to convert the velocity obtained by the 0.2 - and 0.8 -depth method or the 0.6 depth method to the mean velocity. Normally, the average of the velocities obtained by the 0.2 - and 0.8 -depth method gives an acceptable mean velocity, but a coefficient of about 0.92 typically is applicable to the velocity obtained by the 0.6 -depth method.

When measuring the velocity, the meter is kept as far upstream as possible to avoid the effect of the vertical pulsation of water in the hole. Exposure of the meter to cold air during the measurement should be minimized by keeping the meter submerged. The meter must be free of ice when the velocity is being determined.

After the effective depth of the ice cover is determined for a stream free of slush, District policy is to use the same criteria for Price AA or pygmy meter selection as for open-water flows.

\section{PROCESSING AND ANALYSIS OF STAGE AND STREAMFLOW DATA}

The computation of streamflow records involves the analysis of field observations and field measurements, determination of stage-discharge relations, adjustment and application of these relations, and the systematic documentation of the methods and decisions used to compute the record. Streamflow records are computed and published annually for each gaging station (Rantz and others, 1982, p. 544).

This section of the QA Plan describes procedures and policies for the processing and analysis of data associated with the computation of streamflow records. The procedures followed by the Montana District are those described in Rantz and others (1982) and Kennedy (1983).

\section{Discharge-Measurement Field Notes}

The gage-height information, discharge measurements, control conditions, and other field observa- 
tions written by personnel onto dischargemeasurement note sheets and other field note sheets form much of the basis for records computation at each gaging station. Discharge-measurement field notes and other field notes that contain original data need to be stored indefinitely (Hubbard, 1992).

Discharge-measurement field notes for the current water year are filed in each Field Headquarters in an annual computation folder. Measurement field notes for previous water years are backfiled for 5 years by each Field Headquarters and then assembled by the Data Management Unit and sent to the Federal archives in Denver.

District policy requires that all discharge measurements sent to cooperating agencies and those measurements used to develop a new rating curve be checked by reviewing the mathematics and other items listed in Kennedy (1983, p. 6-7). Once the discharge measurements are checked within 2 weeks of returning from the field, field personnel are expected to enter the data into the data base. Measurement field notes are then filed in the annual computation folder.

\section{Continuous Stage Record}

Surface-water gage-height data are collected as continuous record (gage height recorded at hourly, 30minute, or 15-minute intervals, for example). Continuous stage data are recorded as digital punches on paper tape, pen traces on paper, and in electronic media. With the exception of analog pen traces, data are electronically transcribed to computer files for storage in the data base. Streamflow records are computed by converting gage-height record to discharge record using the stage-discharge relation. Thus, the accuracy of computed discharges depends upon the accuracy of gage-height record.

Gage-height record for the period of analysis is compiled as completely as possible. Periods of inaccurate or missing gage-height data are identified and corrected (see the subsection "Datum corrections, gageheight corrections, and shifts" in the section "Discharge Records and Computation") or deleted as appropriate. Items included in the compilation of gage-height record and procedures for processing the data are discussed in Kennedy (1983, p. 7-12) and Rantz and others (1982, p. 560-569 and 587-600).

Gage-height data, except digital tape data, are processed at the Field Headquarters and stored in the computer. Digital tapes and translation instructions are sent, using certified mail, to the Computer Services Unit in Helena, processed, and returned to the Field Headquarters for storage. Field Headquarters are noti- fied when the tapes have been processed and the data have been stored in the data base.

Observer logs of gage-height readings are sent by the U.S. Postal Service from the observer's residence or place of work to the assigned Field Headquarters. Generally, the data arrive at the Field Headquarters written on USGS cards or in USGS observer books. Cards are mailed weekly whereas books are mailed quarterly by the observer. These data are transferred from the cards or books and entered into the computer. Once-daily observer readings of gage height are obtained at nonrecording gage locations and computed as daily mean gage heights. Cards and books are stored for future transfer to the Federal archives.

For stations having more than one recorder collecting gage-height record, one is designated as the primary recorder and the other(s) as backup recorders.

For example, at a station that has a digital and an analog recorder, the digital recorder generally is the primary recorder, and the analog recorder generally is the backup recorder. Likewise, at a station that has a datacollection platform (DCP) for satellite transmission and an analog recorder, the DCP is the primary recorder and the analog recorder is the backup recorder. The purpose of the backup recorder is to verify the gage-height data collected by the primary recorder, to provide stage record should the primary recorder malfunction, and, in some instances, to provide an analog trace of stage that is useful for computation of sediment records.

Because DCP's provide data on a near real-time basis, District policy is to review the DCP data on a daily basis by reviewing hydrographs and visually scanning the hydrographs for periods of missing, incomplete, or obviously questionable data. The Field Headquarters Chief is responsible for ensuring that the gage-height data received from DCP's are reasonable. This procedure is most important for stations displayed on the District World Wide Web Home Page. These stations are viewed by non-USGS data users each day. The District has a responsibility to those data users to supply the most accurate provisional data possible.

\section{Discharge Records and Computation}

Each Field Headquarters is responsible for maintaining surface-water station record files. The station record file includes the current computation folder, the rating and discharge-measurement folder, the historical-data backfile folder, and the station history folder. These files should be located in an easily accessible 
area and clearly labeled with the station name and identification number.

Streamflow records are kept current and final computations are completed by the person assigned to the gaging station prior to publication. Review and checking of the data are performed by staff other than the individual who computed the record. The Chief, HSAS sets the priorities for station-record computation in October and notifies the Field Headquarters Chiefs in writing. Once the station record is finalized and reviewed by the Field Headquarters Chief, the current computation folder and any analog strip charts are sent to the District Office for final review. The Chief, HSAS and the Chief, Data Management Unit are responsible for certifying the record and preparing it for publication in the annual data report, "Water Resources Data, Montana."

\section{Procedures for Working and Checking Records}

Procedures for ensuring the thoroughness, consistency, and accuracy of streamflow records are described in this section. The goals, procedures, and policies presented in this section are included within the separate components of the records-computation process.

Gage height.--The accuracy of surface-water discharge records depends on the accuracy of the discharge measurement, the accuracy of the rating definition, and the completeness and accuracy of the gageheight record (Office of Surface Water memorandum 93.07). Accuracy of the gage-height record is ensured by comparing gage-height readings between independent reference gages. Other comparisons that help ensure accuracy of gage-height readings include comparison of recorded maximum gage height and highwater marks, redundant recordings of maximum and minimum gage heights by use of maximum and minimum indicators, recorded maximum gage heights and maximum gage heights from CSG's.

The gage-height record also is examined to ensure that the record is consistent and complete. Anomalous or inaccurate gage heights and their causes are identified and the gage heights corrected wherever possible. Anomalous or inaccurate gage heights that cannot be corrected are removed from the record.

Final copy of the gage height and discharge record computer printout (primary printout) should contain the daily discharge data to be published. Included on the printout are any computation notes about the accuracy of the record, such as ice-affected or missing gage-height data, or notes pertaining to any record collected from a different instrument and merged into the primary computer gage-height data-set descriptor. For stations that do not have a DCP, primary printout sheets are retrieved from the data base and reviewed generally within 2 weeks following a field trip. Part of that time is used to translate digital punch tape or electronically recorded data and to store the collected gage-height data in the data base. Any shift or datum correction should be entered into the computer before the primary computations are processed. Once the computations are made and the primary sheets are retrieved, the primary sheets are reviewed and any questionable data are corrected or deleted from the computer file and noted on the primary sheets. Missing data are updated when additional information and the data are applied to the record (see Rant $z$ and others, 1982, p. 573). The primary printout becomes part of the historical record and all notes are written clearly and concisely using accepted WRD terminology. Individuals responsible for the processing and storing of the primary gage-height data are those who collect the data at the gage, unless otherwise directed by the Field Headquarters Chief. The primary printout is assembled in chronological order and submitted for final review. The primary printout with any computation remarks and updates are reviewed by the record checker and the Field Headquarters Chief prior to submitting the record to the District Office for publication.

Gaging stations that use DCP data as the primary record should have that record reviewed daily. Any corrections made to the record are noted on the primary printout. Any missing or replaced gage-height data are documented in the station analysis (see "Station Analysis").

Levels.--Errors in gage-height data caused by vertical changes in the gage or gage-supporting structure can be measured by levels. Reference gages can be reset or gage readings can be adjusted by applying corrections based on levels (Kennedy, 1983, p. 6).

Rating.--The development of the stage-discharge relation, also called the rating or the rating curve, is one of the principal tasks in computing discharge record. The rating typically is the relation between gage height and discharge (simple rating). The rating for some special sites involves additional factors such as rate of change in stage or fall in slope along a channel reach (complex rating) (Kennedy, 1983, p. 14).

For each gaging station, the most recent rating table and graph can be obtained by accessing the computer or retrieving a paper copy from either the historical backfile, the field notebook, or the Field Headquarters computation folder, or by asking the Field Headquarters Chief or Chief, Data Management 
Unit. A copy of the most recent rating table is also located at each gaging station. If space permits, a copy of the graph is located there also.

New discharge rating curves and tables are developed and reviewed in the originating Field Headquarters. Complex rating curves, those having a variable relation of stage to discharge, should be reviewed by the Chief, HSAS. A new rating table generally is developed from the curve produced by a series of gageheight versus measured discharge plotted on logarithmic-scaled paper. (For a complete explanation of how to develop, modify, and apply discharge ratings, see Rantz and others, 1982, p. 285, and Kennedy, 1983, p. 14.) All ratings are checked by the Field Headquarters Chief before copies are sent outside the office.

Datum corrections, gage-height corrections, and shifts.--A correction applied to gage-height readings to compensate for the effect of settlement or uplift of the gage is usually measured by levels and is called a "datum correction" (Kennedy, 1983, p. 8-9). Datum corrections are applied to gage-height record in terms of magnitude (in feet) and in terms of the time when the datum changed. In the absence of any evidence indicating exactly when the datum changed, the change is assumed to have occurred gradually from the time the previous levels were run, and the correction is prorated with time (Rantz and others, 1982, p. 545). Datum corrections are applied when the magnitude of the vertical change is equal to or greater than $0.02 \mathrm{ft}$ and are documented in the station analysis.

A correction applied to gage-height readings to compensate for differences in data between the recording gage and the reference gage is called a "gage-height correction" (Rantz and others, 1982, p. 563). These corrections are applied in the same manner as datum corrections. Gage-height corrections are applied to make the recorded data agree with reference-gage data. These corrections are applied when the difference in datum between the recording gage and the reference gage is equal to or greater than $0.02 \mathrm{ft}$.

A correction applied to the stage-discharge relation, or rating, to compensate for variations in the rating is called a "shift." Shifts "reflect the fact that stagedischarge relations are not permanent but vary from time to time, either gradually or abruptly, because of changes in the physical features that form the control for the station" (Rantz and others, 1982, p. 344). Shifts can be applied to vary in magnitude with stage and/or with time (Kennedy, 1983, p. 34). When computing the annual discharge record, stage shifts rather than time shifts are used. As stated in Office of Surface Water memorandum 88.03, OSW requires that "all shift adjustments in ADAPS be specified by means of the shift-by-stage procedure." Using current NWIS computer software, the shift-by-stage procedure can distribute shifts on the basis of both stage and time. The memorandum specifies that "shifts by time can be applied by using a constant stage-shift-variation diagram at each end of the time interval for which time shifts are desired." All shifts are entered and reviewed in the computer using current NWIS software. A paper copy of the computer-generated shift analysis indicating how the shifts were distributed is retrieved and included in the annual computation folder. Written comments on this retrieved page are encouraged. Also, to check shift transition, a plot of the stage-shift-variation diagram is included for review by the Chief, HSAS. After review by the Chief, HSAS, this copy becomes part of the historical backfile. A shift paragraph is included in each gaging station's station analysis which narratively describes how, if any, shifts-bystage were distributed.

Hydrographs and winter records.--A discharge hydrograph is a plot of daily mean discharge versus time. The date is plotted on the horizontal axis and the discharge is plotted on the logarithmic vertical axis. In the process of computing station records, this hydrograph is useful for identifying periods of erroneous record, such as might be caused by incorrect shifts or datum corrections. Additionally, hydrographs are helpful when estimating discharges for periods of undefined stage-discharge relation, such as during backwater or ice conditions, and when estimating discharges for periods of missing record.

A discharge hydrograph is prepared for all gaging stations. The hydrograph is a general picture of flow patterns at a gaging station and shows enough detail to enable a user to ascertain stream precipitationresponse and recession characteristics more than could be obtained from tabulations of data.

Information placed on the discharge hydrograph for each station includes station name, station number, water year, plot of daily mean discharge data, plots of numbered measurements, instantaneous annual peak flow streamflow stations with which the hydrograph was compared and, if needed, precipitation, air, and water-temperature data. If other station records are plotted on the same hydrograph, use of a different color for each station is a practical way to clearly indicate the record at each station.

For gaging stations where the stage-discharge relation is affected by ice during winter, computation of discharge in the usual manner may become impossible. "The formation of ice in stream channels or on section controls affects the stage-discharge relation by causing backwater that varies in effect with quantity and nature of the ice, as well as with discharge" (Rantz and others, 
1982, p. 360). Several different methods can be used to estimate the discharge during ice-affected periods, depending on the type of information available at a station.

The following method of estimating discharge can be used if the gage-height record is complete during the ice-affected period, if the discharge is measured regularly, and if the stream has an almost complete ice cover throughout the ice-affected period. First, plot air temperature and precipitation record from a nearby National Weather Service station, a Natural Resources Conservation Service snotel site, or air temperature recorded at the gaging station by a data-collection platform or data logger. This plot is used to ascertain the freeze or thaw potential of the stream. Next, plot on the hydrograph the apparent discharge calculated by applying the mean daily gage height minus the open-water shift adjustments to the open-water rating table. If a computer hydrograph is used, the non-ice-affected discharges are already plotted. Notes of climatic and hydrologic conditions observed by field persons and observers should be transferred to the hydrograph, and written vertically on the day to which the note applies. If known, notes are added about winter discharge measurements as to whether or not they represent the mean discharge for the day.

Some streams remain open and free from ice most of the time because of warm springs, and others remain open because the control is covered and heated. If applicable, the hydrograph from one of these stations is used as a guide in estimating winter discharges at nearby ice-affected stations.

At other stations, ice is intermittent or infrequent. When estimating the discharge for these stations, the recorded gage-height data are carefully examined, and appropriate consideration given to the open-water part of the day.

At stations where recorders are not operated but discharge is measured, the discharge is estimated on the hydrograph from comparison with a nearby, preferably open-water, station and the temperature graph. If daily discharges are estimated on the hydrograph, these will be shown on the primary printout and entered in ink after the record is checked. All periods of estimated daily discharges are shown on the hydrograph as dashed lines. After the hydrograph has been computed and periods of backwater effect or missing periods of record have been reviewed by the Field Headquarters Chief, the hydrograph is temporarily stored in the computation folder for review by the Chief, HSAS. After review by the Chief, HSAS, the hydrograph is stored with the other annual computation data in the historical backfile located in the Data Management Unit.
Periods of estimated daily discharges are identified on all published daily value tables with an "e." For stations with estimated record, "e--Estimated," is footnoted on the bottom of the page for the station in the annual report.

Station Analysis.--A complete analysis of the data collected, the procedures used in processing the data, and the logical basis of the computations are documented in the station analysis for each year of record. This document provides a basis for review and serves as a reference if questions arise in the future about the records (Rantz and others, 1982, p. 580). Topics discussed in detail in the station analysis include equipment, gage-height record, datum corrections, rating, determination of discharge, extremes, and remarks. The station analysis is written by the individual who prepares the initial determination of discharge. This is commonly the field person who is assigned to the gaging station. The station analysis should be written clearly and concisely and should include all information pertinent to final streamflow determinations. Figure 10 is an example of a station analysis.

Once written, the station analysis is filed in the computation folder with all information that was used to compute the record. The computation folder includes the station analysis, daily mean discharge table, current rating table, current rating curve, listing of discharge measurements, primary computation of gage heights and discharge printout, marked-up publication manuscript page, shift and datum diagrams, hydrograph, peak discharge sheet, shift analysis form, shift-variation form, record computation checklist, Montana District form entitled "Form for Completing Station Analysis" (fig. 11), and any other pertinent station record information. When the record has been computed, a person is assigned to check the record and the station analysis. This person is responsible for the accuracy of the entire record and station analysis. By signing the station analysis, the person certifies that the record with the supporting information is complete and accurate. If questions arise between the preparer of the record and the assigned checker, the order of responsibility for resolving disputes is: (1) Field Headquarters Chief, (2) Chief, Data Management Unit, (3) SurfaceWater Specialist, and (4) Chief, HSAS.

An original signed copy of the station analysis is filed in each station history folder. These station history folders are maintained in each Field Headquarters and a complete set of history folders is maintained in the District Office.

Data received from non-USGS sources.--Surface-water data collected under the supervision of other agencies, organizations, or institutions are received in 


\section{STATION ANALYSIS}

Flint Creek at Maxville

Station number: 12329500

EQUIPMENT.--Fischer-Porter digital (30 min punch cycle) and Stevens A-35 (1:6 scale) water-stage recorders are attached to separate floats in a wooden gage house over a timber well. Recorders are referenced to the inside staff gage. Outside staff gage is attached to the upstream side of the gage house. Fisher-Porter digital recorder replaced with a Stevens \& Leopold digital recorder on Oct. 10. Stevens \& Leopold recorder malfunctioned beginning Jan. 7 and was replaced with a Fischer-Porter on Feb. 21.

GAGE-HEIGHT RECORD.--Record was complete for the year except for Nov. 3-7, Dec. 16 to Jan. 14, and Feb. 8, when the float was frozen in the well. Upon reviewing digital data for the period Jan. 7 to Feb. 21, it was found that the recorder was missing or adding erroneous values to unit punches. Corrections were applied to unit values based on adjacent punch values.

Gage-height record is considered fair due to problems with seiche in well. Gaps in timbered stilling well allow stream wave action to influence water surface in well, especially during stages above $3.0 \mathrm{ft}$. The resultant fluctuations may span 0.1- $0.2 \mathrm{ft}$, making it difficult to ascertain an accurate stage reading.

DATUM CORRECTIONS.--Last levels were run on July 6, 1995, using RM 1 as base and no corrections were required. Datum corrections were used to correct erroneous unit value punches from the malfunctioning digital recorder. Due to the frequency and nature of the corrections, refer to the table of "Datum Correction Values" found in the yearly computation folder.

RATING.--The control is a silt and gravel riffle $15-20 \mathrm{ft}$ below the gage at stages below $2.3 \mathrm{ft}$. At higher stages a small boulder and gravel riffle control about $120 \mathrm{ft}$ downstream of the gage becomes effective. The low water control is unstable, with silt and fine gravel moving on and off the riffle. Left bank is brush covered and will overflow at a stage of about $5.7 \mathrm{ft}$. Right bank is grass covered and not subject to overflow in the vicinity of the gage.

On Feb. 1, 1995, a log stringer of the old mine access bridge located $200 \mathrm{ft}$ downstream collapsed into the stream. Subsequent accumulation of debris and beaver activity caused variable backwater conditions to exist at the site until debris was removed by county road crew sometime between Dec. 15, 1995 and Jan. 16, 1996 to prevent localized flooding.

Eleven discharge measurements (nos. 600-610) were made this year. Measurement nos. 599, 611, and 612 were also used in the rating analysis. Measurements ranged in discharge from 69.6 to $730 \mathrm{ft}^{3} / \mathrm{s}$, while recorded mean discharge ranged from 43 to $766 \mathrm{ft}^{3} / \mathrm{s}$. Nos. 600 and 610 were made during variable backwater conditions created by the collapsed bridge and no. 603 was made during ice conditions. Rating No. 11 (in use since Oct. 1, 1989) was continued in use this year and was extended from $4.2 \mathrm{ft}$ to $6.7 \mathrm{ft}$ based on measurement nos. 604 and 605 . Measurements made at the beginning of the water year and into the winter period plotted to the left of the rating due to backwater from debris in stream. Peak flows in February scoured the control riffle based upon subsequent measurements.

DETERMINATION OF DISCHARGE.--Daily mean discharges were computed using the processed digital gageheight record and Rating No. 11 with shift and datum corrections applied as described in this report.

Four stage-variation diagrams were used in this year's computation. The first two (V1 and V2) were defined by the measurements made during backwater conditions from the collapsed bridge. These diagrams were applied by time between visits. A third diagram (V3), defined by measurement no. 602, was used during the ice free periods in January and February following the removal of debris from stream. The Feb. 8-10 runoff event scoured the channel, and a fourth diagram (V4), based upon measurement nos. 606-612, was used until the end of the water year.

Discharge for the periods of missing and ice-affected record (Nov. 1-9, 19-20, Dec. 4 to Jan. 14, Jan. 20 to Feb. 3, Feb. 8, Feb. 27-29, Mar. 6,7, 25) were estimated based upon adjacent ice-free record, hydrographer notes, a fair hydrographic comparison with Flint Creek near Drummond, MT, and weather records at Philipsburg, MT.

EXTREMES.--Maximum discharge was $1,040 \mathrm{ft}^{3} / \mathrm{s}$, gage height, $6.68 \mathrm{ft}$ (verified with graphic record), on Feb. 9 at $0330 \mathrm{hrs}$. Minimum daily was $43 \mathrm{ft}^{3} / \mathrm{s}$ and occurred on Feb. 4 .

REMARKS.--Records are fair except for estimated daily discharges, which are poor.

Computed by: D.A. Bischoff

$10-31-96$

Checked by: N.A. Midtlyng

$11-25-96$

Reviewed by: R.R.Shields

01-09-97

Flint Creek at Maxville, MT

12329500

Page 1 of 1

Figure 10. Example of streamflow-gaging station analysis. 


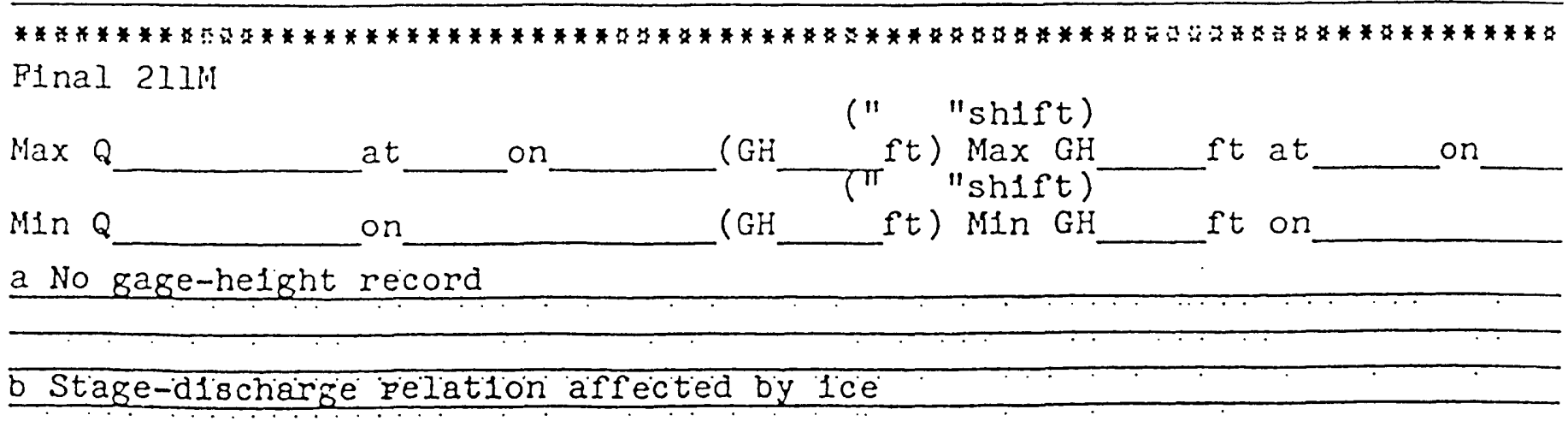

Peak discharge (base, ciss)

Rating No.

Comp:

checked

Figure 11. Example of form for completing station analysis.

the District Office. These data are reviewed and published in the annual data report. Two types of data are received from cooperating agencies. The first type of data--the daily mean discharge data--are sent to the Montana District on monthly sheets and are supplied by agencies releasing water from large dams. These data are verified by an occasional WRD discharge measurement near the dam. Daily mean discharge data are taken from the supplied sheets and entered into the data base. At the end of the water year, the data are retrieved from the computer and a manuscript prepared and the data published. Credit is given to the supplying agencies. The second type of data comes from cooperating agencies supplying daily or monthend reservoir data. Generally, the supplied data are published as monthend contents; however, a few stations are published with daily or monthend elevations. Annual reservoir manuscripts are prepared for all furnished record stations and credit is given to the supplying agencies. The Data Management Unit is responsible for preparing non-USGS records for publication in the annual data report.

Daily mean discharge table.--A daily mean discharge value is determined and stored for most gaging stations operated by the WRD. The daily mean discharge table generated by use of the records-computation software represents the mean discharge stored for each day.

When computing the discharge record, the final table of daily mean discharge values is to be checked against the primary printout and the hydrograph to ensure that the correct values are consistently present on each form. A check mark and reviewer's initials should be noted on these forms to indicate who has reviewed these data. The final daily values table is combined on a single page with the updated manuscript by Field Headquarters personnel, and the merged copy is placed in the computation folder for review by the Chief, HSAS. Manuscript corrections and the final review of the daily values data are made in the Data Management Unit.

Manuscript and annual report.--When records computation for the year has been completed and the data collected and analyzed by District personnel have been corrected and finalized, the surface-water data for that water year are published along with other data in the District's annual data report. The annual data report is part of the series titled "U.S. Geological Survey Water-Data Reports." Information presented in the annual data report includes daily mean discharge val- 
ues, extremes for the year and period of record, and other statistics. Additionally, manuscript station descriptions are presented in the annual data report. Information contained in the manuscript includes physical descriptions of the gage and basin, history of the station and data, and statements of cooperation. In preparing the annual data report for publication, the District follows the guidelines presented in the report, "WRD Data Reports Preparation Guide," (C.E. Novak, U.S. Geological Survey, written commun., 1985).

The Data Management Unit is responsible for preparing the annual data report. Finalized records are received from the Field Headquarters and reviewed by either the Chief, HSAS or the Chief, Data Management Unit. Once the record is approved for publication, the manuscript is updated in the computer and a cameraready page is printed and reviewed. Additional copies of final camera-ready pages are: (1) filed, by water year, in historical backfiles located in the Data Management Unit or the International Waters Section, (2) returned to the Field Headquarters for next year's markup, and (3) temporarily stored with other approved manuscript pages in the Data Management Unit. Eventually, these pages are filed in the station history folders.

Before the annual data report is mailed to the printer using certified mail, the individual station pages are assembled by major drainage basin in downstream order. These pages are then assembled with introductory pages and a copy of the data book is printed and reviewed by Data Management Unit personnel. The Chief, Data Management Unit is responsible for the accuracy of and for overseeing the preparation, review, and publication of the annual data report. The Montana District's goal is to mail the report to the printer within 6 months after the end of the water year.

\section{District Checklist}

The Montana District uses two different computation checklists (figs. 12 and 13). These quarterly or annual gaging station checklists are used for tracking the status of record computation for each station and ensuring that errors do not occur by omitting the necessary procedural steps. Another use for the checklist is to let the reviewer know whom to contact if questions arise later. The list with quarterly reporting periods is the more current, but both are used and acceptable. Checklists are available in each Field Headquarters and are kept in the record computation folder throughout the whole computation and review process. Once the record is reviewed, the completed computation checklist is backfiled along with the other computation data in the Data Management Unit or International Waters Section.

\section{Review of Streamflow Records}

After streamflow records for each station have been computed and checked, records for all District gaging stations are reviewed by the Chief, HSAS or the Chief, Data Management Unit. This final review is to ensure that proper methods were applied when obtaining the surface-water data and computing the record. If procedural errors are noted, Field Headquarters personnel are contacted and the record is discussed. This first communication usually results in resolution. Occasionally, a record is returned to the originating Field Headquarters for rework, with deficiencies noted in writing. After the deficiencies are corrected, the record is returned to the District for processing. Disputes are officially resolved by, in order, Chief, Data Management Unit, Chief, HSAS, or Surface-Water Specialist.

\section{Crest-Stage Gages}

The instantaneous annual peak-discharge records for CSG's are computed by using procedures similar to those for continuous-flow gaging stations. The CSG inspection forms are examined for completeness and accuracy. Peak stages recorded by CSG's are cross referenced with other available information; the dates of the peaks are determined by analyzing available precipitation data and peak data from recording gages in the same basin or nearby basins.

The policies and procedures used in the field for collecting data at CSG's are described in this report in the section "Collection of Stage and Streamflow Data." This section describes the analysis and office documentation of crest-stage data. It does not pertain to data collected at CSG's installed solely for confirming peak stages at continuous-flow gaging stations.

At sites where CSG data are used to compute peak discharges, the initial stage-discharge relation is developed for the site by direct or indirect discharge measurements. The rating is verified or adjusted on the basis of subsequent direct or indirect discharge measurements.

For each gage, a list of all measurements is maintained and each measurement is assigned a chronological number. For each gage, a graph and table of the current rating along with each recent and high stagedischarge measurement are made available to those checking and reviewing the station record. Current station descriptions and a summary of levels are main- 
WATER-YEAR RECORD

COMPUTATION CHECKLIST

YEAR:

STATION:

NO.

\begin{tabular}{l|l|l|l|l|l|l}
\hline \multicolumn{1}{c|}{ OPERATION } & $\begin{array}{c}\text { OCT- } \\
\text { DEC }\end{array}$ & $\begin{array}{c}\text { JAN- } \\
\text { MAR }\end{array}$ & $\begin{array}{c}\text { APR- } \\
\text { JUN }\end{array}$ & $\begin{array}{c}\text { JUL- } \\
\text { SEPT }\end{array}$ & DONE BY & CHECK BY \\
\hline $\begin{array}{l}\text { Enter gage heights into ADAPS from charts, } \\
\text { tapes, DCP }\end{array}$ & & & & & & \\
\hline $\begin{array}{l}\text { Complete level summary sheet and determine } \\
\text { datum corrections }\end{array}$ & & & & & & \\
\hline $\begin{array}{l}\text { Apply datum corrections to gage-height record } \\
\text { and measurements }\end{array}$ & & & & & & \\
\hline $\begin{array}{l}\text { Check measurements (data and gage-height) } \\
\text { then list/enter on 9-207/ in ADAPS }\end{array}$ & & & & & & \\
\hline
\end{tabular}

DONE BY CHECK BY

REMARKS

\begin{tabular}{l|l|l|l}
\hline $\begin{array}{l}\text { Plot measurements on curve, and draw new } \\
\text { curve and rating, if necessary }\end{array}$ & & & \\
\hline $\begin{array}{l}\text { Compute shifts, percentages; draw V-diagram, } \\
\text { if necessary }\end{array}$ & & & \\
\hline $\begin{array}{l}\text { Run primary computations with datum } \\
\text { corrections and shifts }\end{array}$ & & & \\
\hline $\begin{array}{l}\text { Retrieve hydrograph with winter temperatures } \\
\text { and comparisons }\end{array}$ & & & \\
\hline $\begin{array}{l}\text { Estimate discharges for winter and periods of } \\
\text { missing record }\end{array}$ & & & \\
\hline $\begin{array}{l}\text { Enter "e" days into ADAPS and retrieve final } \\
\text { listing (9-211M) }\end{array}$ & & & \\
\hline Retrieve final hydrograph PLOTWAT & & & \\
\hline $\begin{array}{l}\text { Compute max, min, peaks above base, and } \\
\text { mean annual discharge }\end{array}$ & & & \\
\hline Complete station analysis and initial all forms & & & \\
\hline $\begin{array}{l}\text { Update station description, 9-220 and station } \\
\text { manuscript }\end{array}$ & & & \\
\hline
\end{tabular}

Computed by:

Date:

Checked by:

Date:

Reviewed by:

Date:

Additional checker/reviewer comments:

Figure 12. Example of water-year record computation checklist. 
1. Check level notes, update summary sheet

2. Check measurement gage heights and dates, apply datum corrections

3. List measurements on 9-207 in ADAPS (HT-1)

4. Plot measurements on rating curve

5. Rating curve drawn, table developed (PR-1)

6. Run shift analysis (HT-5)

7. Shifts and datum entered in ADAPS (PR2-4).

8. Run primary computations (PR-7)

9. Estimate discharges for winter and missing periods of record

10. Enter "e" days into ADAPS (PR-8), update primary sheets

11. Retrieve final 9-211M (PR-9)

12. Run final hydrograph (Calcomp or Plotwat)

13. Determine max. and min. Q (HT-6), plot on rating curve and hydrograph; list with "a, b" days

14. Compute peak discharges (HT-6)

15. Update 9-220's, compute average discharge

16. Update station manuscript

17. Station analysis written and typed (EMACS)

18. Update station description

Computed by:

Date:

Checked by:

Date:

Reviewed by:

Date:

Additional checker/reviewer comments:

Figure 13. Example of record computation checklist. 
tained in each Field Headquarters and in the Hydraulics and Hydrology Unit.

The Field Headquarters Chief is responsible for assigning the personnel for the collection of data at each CSG. The Field Headquarters Chief also checks computations and, if changes are needed, discusses those changes with the person who computed the record. The Chief, Hydraulics and Hydrology Unit is responsible for ensuring the correct computation of annual peaks at CSG's. Crest-stage gage computations are reviewed by the Chief, Hydraulics and Hydrology Unit or the assigned employee. When incorrect actions or procedures are identified during the review, the problems are remedied by first contacting the Field Headquarters Chief and then, if necessary, the individual who computed the record.

Personnel in the Hydraulics and Hydrology Unit have the responsibility for updating the NWIS PeakFlow File promptly after the peak data have been finalized. A current list of annual peaks is maintained in computer files and in the station folder for review (Office of Surface Water memorandum 88.07). The Hydraulics and Hydrology Unit maintains a list of historical peaks at crest-stage gages and continuous-flow gaging stations.

\section{COLLECTION OF SEDIMENT DATA}

Surface-water activities in the District include the collection, analysis, and publication of sediment data. The District adheres to policies related to sediment data as set forth by OSW.

Responsibility for the sediment discipline was transferred from the Office of Water Quality (OWQ) to OSW in 1985 (Office of Surface Water memorandum 92.08). The policies and procedures related to sediment followed by the District are described in selected WRD publications and in memorandums issued by OSW, OWQ, and WRD. Techniques for sediment QA adopted by the USGS and followed by the District are presented in Knott and others (1992) and Lambing and Dodge (1993). The District also follows procedures for the collection and computation of sediment data as presented in three publications of the series "Techniques of Water-Resources Investigations of the U.S. Geological Survey" (TWRI):

Book 3, Chapter C1--"Fluvial Sediment Concepts" by Guy (1970),

Book 3, Chapter C2--"Field Methods for Measurement of Fluvial Sediment" by Guy and Norman (1970),
Book 3, Chapter C3--"Computation of

Fluvial-Sediment Discharge" by Porterfield (1972).

No additional TWRI chapters have been written to supersede the above-mentioned reports. However, Open-File Report 86-531 "Field Methods for Measurement of Fluvial Sediment" by Edwards and Glysson (1988) essentially replaces Book 3, Chapter C2.

Office of Surface Water memorandum 92.08 summarizes memoranda issued since 1971 related to sediment and sediment transport. Office of Surface Water memorandum 93.01 summarizes documentation of instrumentation and field methods for collecting sediment data.

\section{Sampling Procedures}

Field methods for sediment sampling are documented in Edwards and Glysson (1988). District personnel collect depth-integrated suspended-sediment samples using the following sampling methods: the single vertical method, the Equal Discharge Increment (EDI) method, and the Equal Width Increment (EWI) method. Automatic pumping-type samplers are not currently used.

Occasionally, observers are contracted to collect sediment samples at daily sediment stations. Normally, these samples are depth-integrated single-vertical samples collected near midstream. Training in sampling techniques and safety are provided to the observers by USGS personnel prior to collecting samples. USGS personnel concurrently collect single-vertical samples and cross-section samples to verify accuracy of singlevertical samples. The sediment laboratory supervisor evaluates the compatibility of data collected by observers and USGS personnel.

The District Sediment Specialist or a designated technician is responsible for scheduling and providing training for sediment-collection activities in the District. This individual establishes whether or not correct procedures are being used by periodically accompanying personnel on sampling trips to review procedures and by reviewing results of QA replicate samples. Communication occurs routinely to discuss field situations, and periodic District conferences provide refresher training in concepts of sediment sampling. Answers to questions from District personnel concerning sediment-sampling techniques are provided by either the District Sediment Specialist or the designated technician. 


\section{Field Notes}

District personnel are required to fill out field note sheets each time a site is visited for the purpose of sediment sampling (fig. 14). The employee completes the field note sheet in its entirety before leaving the site. Original observations written on the note sheets are not to be erased; data are corrected by crossing out the original observations and writing the correct information near the original notation. For each site visit, information included on the field note sheet includes, at a minimum: site identification, field personnel name, date, time, sampling equipment, method, type of sample collected (concentration/sand-fine break), description of sampling points, and project account number. Additional documentation may include flow, weather, and relevant hydrologic conditions or changes. Upon completion of each field trip, field notes are given to the District Sediment Specialist for review. The Sediment Specialist in turn forwards them to the Data Management Unit for filing.

\section{Equipment}

Care and maintenance of the sediment-data-collection equipment are the responsibility of the field personnel who use the equipment. Parts replacement and repair of damaged equipment are accomplished by returning the equipment to the District Sediment Specialist or the designated technician. Field personnel or the project chief are responsible for ensuring that appropriate equipment is used at all sampling sites. Sampling equipment is selected on the basis of site conditions, such as velocity and maximum depth of water, to ensure that design limitations of the equipment are not exceeded. The District follows equipment-design criteria and guidelines referenced in Office of Surface Water memorandum 93.01 and Edwards and Glysson (1988).

\section{Sample Handling and Analysis}

The quality of sediment data provided by a sediment laboratory is partly dependent on the quality of the samples received from the field (Knott and others, 1992 , p. 2). In addition to using proper sampling techniques, District personnel are required to document all pertinent information necessary to accurately process samples through the District sediment laboratory. A detailed description of sediment analysis procedures and associated quality assurance used by the Montana District is presented in Lambing and Dodge (1993).

\section{High-Flow Conditions}

High-flow conditions at most streams, unless the streams are subject to the effects of backwater, are associated with high-energy conditions. The sediment load and particle sizes associated with high flows are significant factors in sediment studies performed by the District. To ensure that field personnel are aware of their responsibilities in obtaining sediment samples at appropriate sites during high-flow conditions, required samples are scheduled to be collected during typical high-flow periods. The project chief, project field coordinator, or designated technician is responsible for ensuring that sediment samples are obtained during opportunities provided by high-flow conditions. The field person is responsible for ensuring that the proper sampling equipment and methods are used during highflow conditions. High-flow conditions can create dangerous sampling conditions and all field personnel must ensure their personal safety. The District Sediment Specialist is responsible for providing answers to District personnel who have questions concerning high-flow sampling equipment or sampling procedures.

\section{Cold-Weather Conditions}

Sediment-sampling activities include obtaining samples during periods of subfreezing temperatures. During cold-weather conditions, field personnel should take every precaution to ensure their personal safety. Additionally, field personnel should attempt to ensure that equipment is not damaged by floating slabs of ice and that nozzles are not clogged with ice crystals.

When floating slabs of ice pose the danger of damaging sampling equipment, such as during spring breakup, field personnel may manage to obtain only surface samples between the floating slabs of ice (Edwards and Glysson, 1988, p. 86). The procedure is noted on the field note sheet and sample label. When anchor ice and frazzle ice are present, the sampling equipment may need to be moved quickly through ice crystals to avoid clogging the nozzle. This procedure is also noted on the field note sheets and sample label.

\section{Site Documentation}

A sediment sampling instruction form is prepared for each new sediment-sampling site. At daily sediment sampling sites where streamflow-gaging activities occur and a daily record of suspended-sediment discharge is computed, the description of sediment activities and sediment equipment is included in a daily sediment station sampling instruction (fig. 15). 


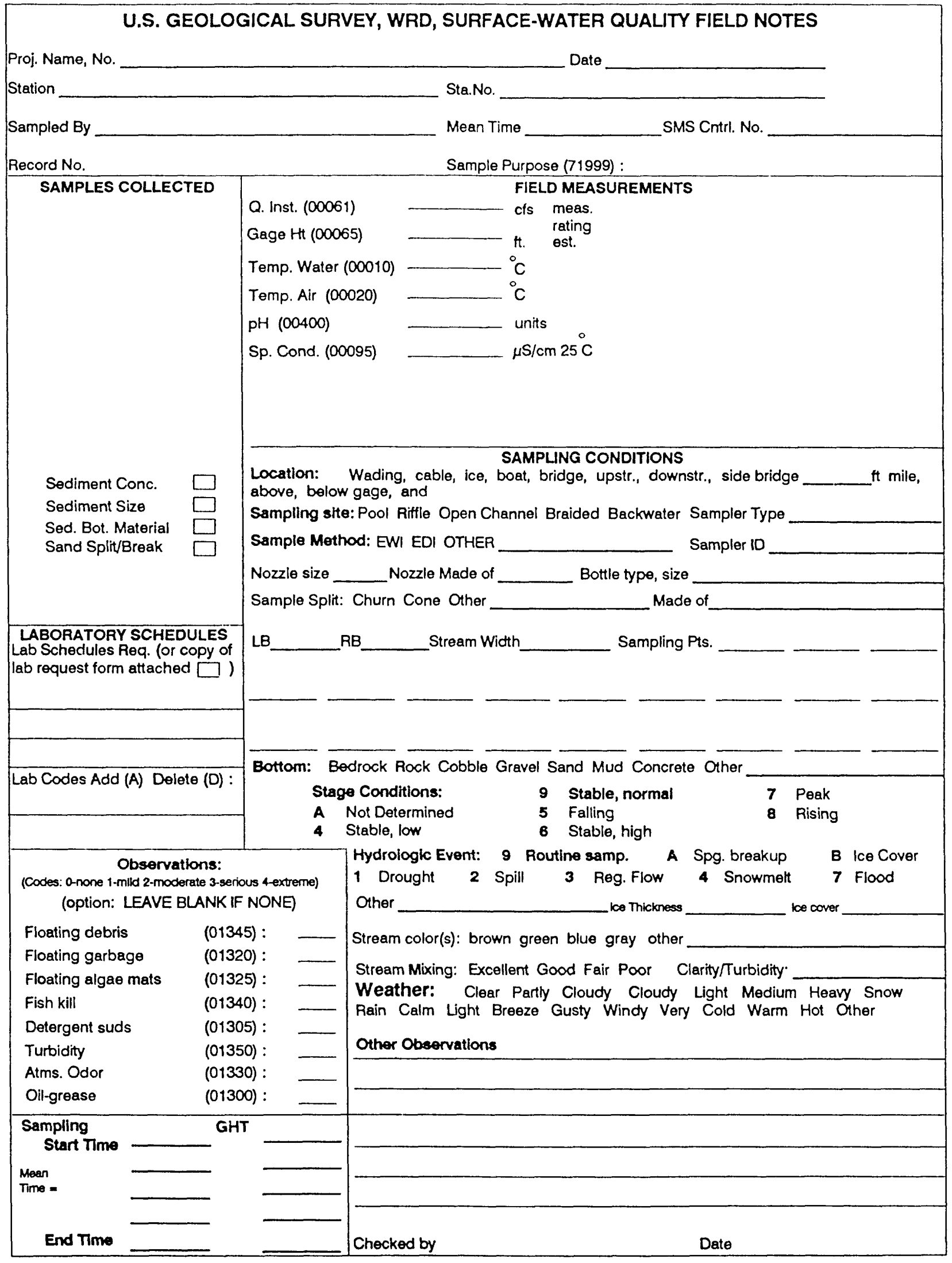

Figure 14. Example of surface-water quality sediment field notes. 


\section{WATER-QUALITY SAMPLING INSTRUCTIONS, 1997 WY \\ 06329500 YELLOWSTONE RIVER NEAR SIDNEY, MT \\ Daily Sediment Sampling Site \\ 1996 WY}

Cooperator:

Observer:

Laboratory:
U.S. Army Corps of Engineers

Harold Emly, Box 4017, Sidney, MT (Phone 482-1149)

Concentration and sand-silt break - Helena, MT

Complete particle size - Iowa City Sediment Lab

Field personnel are to work closely with observers and be prepared to advise them on sampling modifications due to changing stream conditions. Observer should be visited on a regular basis during scheduled visits, or contact is to be made by phone.

\section{DAILY SAMPLES - OBSERVER:}

Suspended Sediment: Collected by the observer once-daily March (or ice breakup) through June, every third day July through November. No samples are collected December through February. Twice-daily samples are requested during large storm events.

Equipment - D-49, P-61.

Location - cableway at gage site, 200 feet downstream from state Highway 23 bridge and 2.5 miles south of Sidney.

Method - Depth integrated EDI at centroids of 3 equal discharge increments $(17,50,83$ percent of flow).

Quantity - One pint bottle at each centroid of equal discharge.

\section{USGS FIELD PERSONNEL:}

Suspended Sediment: Collected as part of routine NASQAN sampling, plus the yearly snowmelt peak and any major storm.

Equipment - D-74, D-77, and P-61, to be used as depths and velocities warrant.

Location - From cableway at gage site.

Method - EDI at centroids of 5 equal discharge increments (the same centroids as used for chemical sampling). During the NASQAN cross-sectional survey (two 3-liter bottles at each of 5 verticals), samples should also be collected at the observer's verticals (two pint bottles at each of 3 verticals). This annual check will be used to verify the adequacy of sampling at 3 EDI verticals.

Quantity - Two bottles at each centroid of equal discharge for both 3 and 5 vertical EDI samples.

Bed Material: Collected each scheduled visit during open water.

Equipment - BM-54.

Location - From cableway at same 3 EDI verticals by observer used for suspended samples $(17,50$, 83 percent of flow).

Alternative - From cableway at deepest locations where uncompacted material is available.

Quantity - One sample from each EDI vertical. Samples can either be placed in individual 1/2 pint containers or can be composited in a single container if quantities from each vertical are small.

\section{Associated Responsibilities:}

- Show initials on one tag of each X-section sample set for suspended sediment. Also, show initials and number of verticals sampled on the bed material container(s).

- Check sampler nozzles each visit and replace if damaged or worn. Also make sure gasket in sampler head is in place.

- Service and/or repair all equipment used by the observer, including the cablecar braking system, D-49 and P-61 samplers, solenoid battery pack, cable and reel on cablecar, and any winter supplies needed to obtain samples.

- Update flow-distribution curves as least every 2 years to verify the location of the observer's sampling points.

- Provide observer with sufficient supplies of bottles, tags, etc. to last between visits.

** ENSURE THAT ALL EQUIPMENT IS SAFE TO OPERATE **

Figure 15. Example of daily sediment sampling instructions. 
Any sediment sampling equipment mounted at a gaging station is also described in the station description for the gaging station. The instruction includes a description of observer and field personnel responsibilities, sampling frequency, sampling location, and other pertinent information required to ensure proper sample collection and processing. At sites where sediment samples are collected periodically but the site is not a gaging station and a daily sediment record is not computed, station location and pertinent geographic information are recorded on the standard station header form. At the periodic sediment sites, sampling instructions are prepared in the same manner as that for water-quality sampling instructions. Sampling instructions are included in the field folder and are maintained in the office files. Each instruction includes specific information explaining what sampling method is to be used and where the site samples are to be taken.

For all sampling sites, a log of sampling activities is kept as part of the station's annual sampling instructions. This log indicates when samples are to be collected and provides a space to "check off and date" when the sample was collected.

\section{PROCESSING AND ANALYSIS OF SEDIMENT DATA}

Sediment and associated streamflow data are compiled to produce either instantaneous or daily sediment discharge records. Data processing for computer storage of periodic instantaneous sediment measurements consists of tabulation, checking and evaluation, editing, and verification (Office of Surface Water memorandum 91.15). The District follows the principles and guidelines presented in Porterfield (1972), Guy (1969), and Office of Surface Water memorandum 91.15 in processing sediment data.

Sediment data from daily or near-daily samples are used at selected gaging stations to construct a record of daily sediment discharge utilizing the daily streamflow record. Daily sediment records are worked continuously throughout the year, as laboratory and streamflow data are received. A checklist outlining procedures is used to track progress in compilation of data (fig. 16). All records are completed and checked by personnel who have sediment-record experience and who have attended formal training through the National Training Center, Denver, Colo. Deficiencies are discussed with the District Sediment Specialist. Sediment data in computer storage are reviewed during preparation of the annual data report and errors are detected by verification reviews. The Sediment Specialist approves all updates, after review by the designated technician.

The District Sediment Specialist is responsible for ensuring that appropriate procedures are correctly applied in processing sediment data. When the sediment data are being processed for the year, sediment field notes and work sheets for each site are maintained in the District sediment computation folder. After the record has been completed, sediment field notes and work sheets are maintained in the Data Management Unit.

\section{Sediment Laboratory}

The Montana District operates a sediment laboratory that is equipped to analyze suspended-sediment samples for concentration and sand-silt size break. Analyses are performed on samples submitted by Montana and Wyoming District personnel and periodically from State cooperating agencies. The laboratory is reviewed onsite by appropriate technical or management personnel from OSW approximately every 3 years. These reviews examine all aspects of laboratory operations (Knott and others, 1993, p. 14).

The report, "Quality Assurance for Laboratory Analysis of Suspended-Sediment Samples by the U.S. Geological Survey in Montana" (Lambing and Dodge, 1993), outlines all analytical and quality-assurance activities of the laboratory, and is available upon request from the District Office. An in-house review of all quality-control test results is conducted throughout the year. The results are documented on the Helena sediment laboratory quality-control chart (fig. 17) and an annual report summarizing the results is submitted to the Branch of Quality Systems.

The laboratory supervisor has primary responsibility for ensuring that appropriate equipment and procedures are used in this laboratory. The laboratory is operated according to procedures described in Lambing and Dodge (1993), Knott and others (1992), and Guy (1969). Procedures described in the publications include calibration and maintenance of equipment, analytical and quality-control procedures, and documentation.

In addition to following guidelines and procedures described in the above-mentioned publications, the District adheres to policies described in memorandums issued by OSW, OWQ, and WRD. Policy on accepted methods of sediment analysis is outlined in Office of Surface Water memorandum 93.11. For example, the use of asbestos is no longer permitted in USGS sediment laboratories; therefore, when sediment 


\section{Computed}

Initials Date
Checked Initials Date

1. All concentrations plotted on A-35 chart...

2. Temperature and precipitation listed on

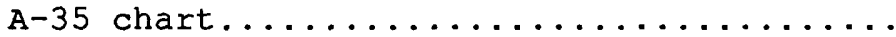

3. Draw sediment concentration curve.........

4. Subdivided days determined.............

* * * RECORDS SENT TO DISTRICT OFFICE FOR PRELIMINARY REVIEW * * *

5. Daily mean concentrations computed........

6. Coefficients plotted on hydrograph form 9-285 or equivalent (can omit if no

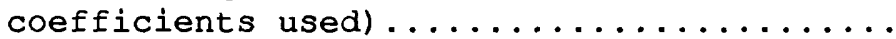

7. Daily coefficient curve drawn (retrieve preliminary streamflow hydrograph for

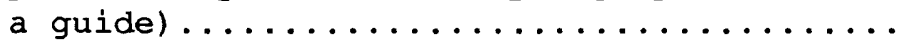

8. Coefficients applied and adjusted mean concentrations calculated on A-35 chart....

9. Subdivided day values listed on computer

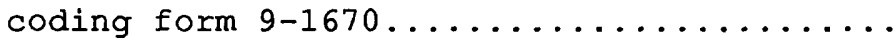

10. Adjusted mean concentrations (except S-days) entered in-house on PRIME and tables of daily sediment concentration, sediment discharge, and streamflow retrieved........

11. Hydrograph of streamflow and daily mean concentrations retrieved (splice

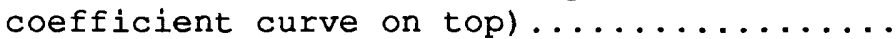

12. Tabulate cross-section summary of suspendedsediment concentration and discharge, and particle size results for suspended and bed

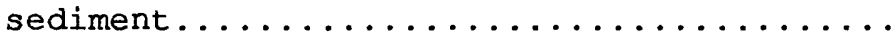

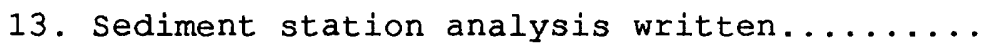
* * * RECORDS SENT TO DISTRICT OFFICE FOR FINAL REVIEW * * *

14. Water-quality manuscript updated (at

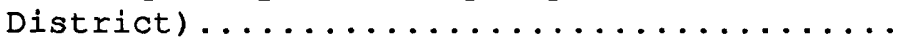

$$
\text { Dates of S-days }
$$

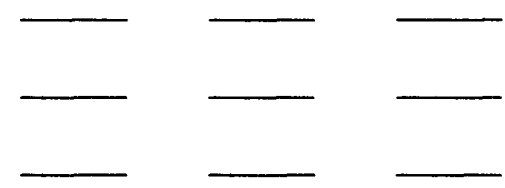

Dates of Size Analysis

Suspended:

Bed :

Figure 16. Example of water-year record sediment compilation checklist. 


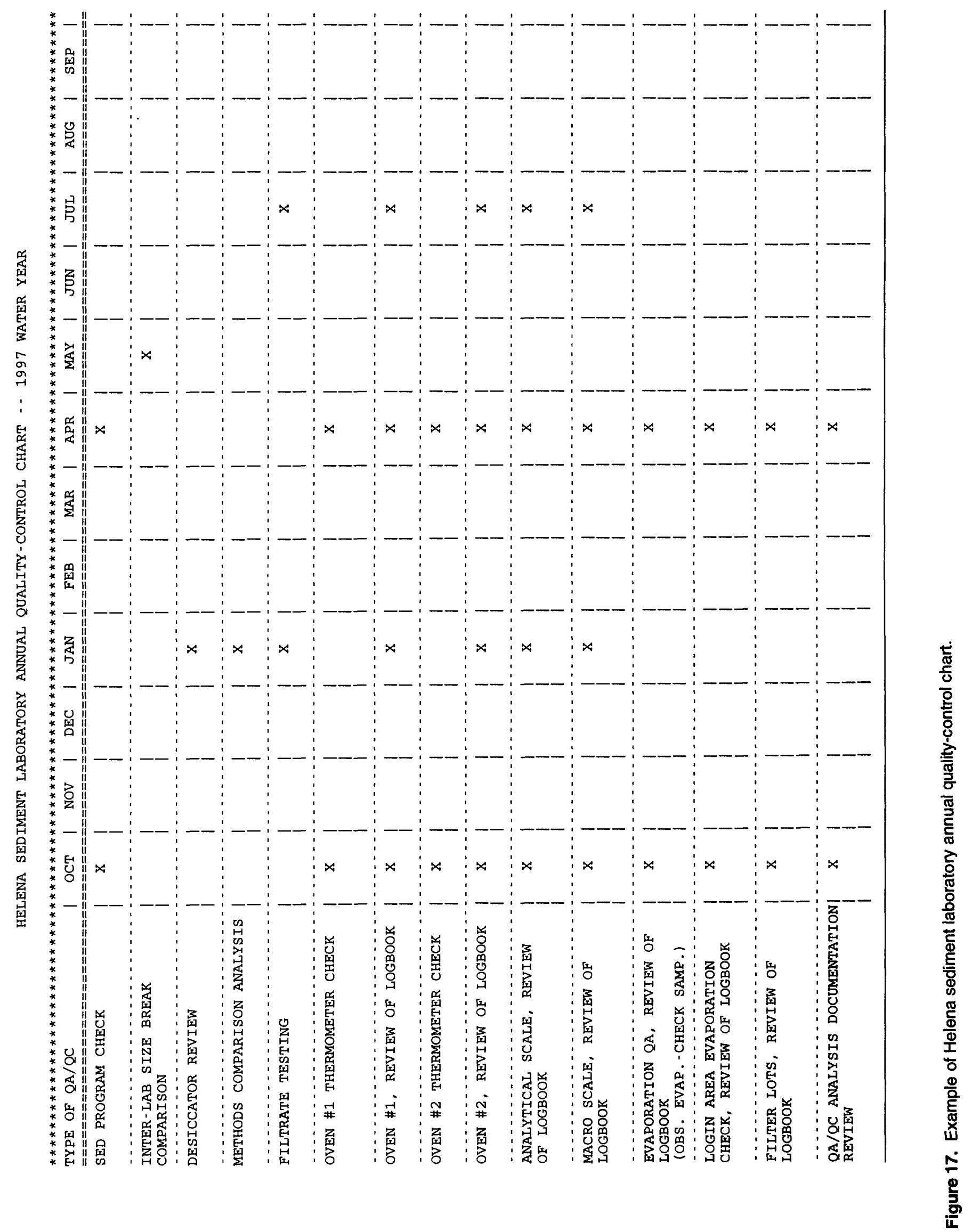


concentrations are determined by the filtration method, the Whatman $934 \mathrm{AH}$ glass filter is used (Office of Surface Water memorandum 92.05).

\section{Sediment Station Analysis}

A sediment station analysis (fig. 18) is written annually for each daily sediment station operated by the District. The sediment station analysis is a summary of the sediment activities and conditions at the station for a given year. The analysis describes the sample coverarge of the year's hydrologic conditions, the types of samples collected, the methods used to compute the record, and any significant changes that might affect the record of sediment transport. Information included in the sediment station analysis is presented thoroughly, such that the checker and the reviewer can determine from the analysis the adequacy of the activities in defining the record and in accomplishing the objectives defined in the sampling instructions for the station (Office of Surface Water memorandum 91.15).

Current daily sediment records are typically maintained by personnel working the station's streamflow record or by personnel of the Water Quality Unit. Upon completion of computations, the record is reviewed by either the District Sediment Specialist or a designated technician. Final approval of the station analysis is given by the District Sediment Specialist. Upon completion of review and approval, the record is backfiled in the District water-quality files, which are maintained by the Data Management Unit. Backfiles are sent to the Federal Records Center (FRC) approximately every 10 years.

\section{Sediment Analysis Results}

Concentration and sand-silt size break results from all periodic cross-section suspended-sediment samples and calculated daily mean concentrations for daily sediment stations are published in the Montana District annual data report. The quality of analytical results is assured by procedures described in "Quality Assurance for Laboratory Analysis of Suspended-Sediment Samples by the U.S. Geological Survey in Montana" (Lambing and Dodge, 1993).

\section{MAINTENANCE OF DATA BASE}

Maintaining surface-water data and related information in a systematic and organized manner increases the efficiency and effectiveness of data analysis and data dissemination. Good organization of files reduces the likelihood of misplaced information. Misplaced data and field notes can lead to analyses based on inadequate information and possibly reduce the quality of analytical results.

This section includes descriptions of how information related to surface-water data are organized and maintained. This section also provides an overview of how work activities are designed for an office setting.

\section{File Folders for Surface-Water Stations}

For each gaging station, a separate set of currentstation-history and backfile folders is maintained in the Field Headquarters and the District Office. Most current-station-history folders are arranged in file drawers in downstream order, and contain published annual report pages, station analyses, historical statistics, station descriptions, correspondence, newspaper clippings, and photographs. Backfile folders contain primary printouts, annual data report pages, hydrographs, variable-shift diagrams, computation checklists, lists of current and historical high-water discharge measurements, rating tables and curves, and other computation material. These data are assembled by water year and stored in envelopes. Backfile folders generally are stored alphabetically and separate from the current-station-history files. Each Field Headquarters is responsible for the storage of data.

The Data Management Unit maintains a complete set of current-station-history and backfile folders. Questions about the content and maintenance of these folders should be directed to the Data Management Unit.

\section{Field-Trip Folders}

The Montana District maintains separate folders for each field-trip area and selected surface-water project study areas. The primary purpose of these folders is to maintain maps, station descriptions, station lists, rating and discharge measurement data, sampling instructions, and other pertinent information for each site. This arrangement allows field personnel to effectively begin trips at a moment's notice. Persons assigned to each gaging station update the field-trip folders as needed.

\section{Level Notes}

Gaging-station and crest-stage-gage level note forms are located in each Field Headquarters. When 


\section{SEDIMENT STATION ANALYSIS}

\section{Clark Fork at Deer Lodge}

Station number: 12324200

Record comp. by: Helena

Program: MT14896
Supervising office: Helena

Cooperator: EPA

\section{SITE OPERATION:}

Procedure:

OBSERVER - Sampled every day March-May, every second day in June, and every fourth day October-February and July-September. No samples were collected during a government furlough from Dec. 15-Jan. 9. Daily sampling is resumed during any runoff conditions that occur. Twice-daily samples are collected during major hydrologic events. Duplicate pint bottle samples are obtained at a single vertical (daily station) from either the bridge or appropriate wading section using the depth-integration method. Water temperature, gage height, sampling location, and river condition are recorded at each sampling visit.

USGS PERSONNEL - Sample 6 times per year with attempts made to sample high flows. Samples are depthintegrated and consist of two cross-section sample sets bracketed by two sets of duplicate samples from the daily station. During low and medium flow, two multi-bottle cross-sectional sample sets are obtained using the EWI method by wading near the gage, or about 300 feet upstream of the bridge. At high flows, the EDI method is used from the bridge at centroids of equal discharge increments (not less than 4).

LOCATION OF DAILY STATION: The daily station at medium and high flows is located on the downstream side of the Milwaukee Street bridge in Deer Lodge, MT, 48 feet from the right edge of water. At low flows, observer's samples are obtained by wading near midstream in the vicinity of the gage.

EQUIPMENT: The observer uses a D-49 suspended by a cable and reel housed inside a small shelter attached to the downstream bridge railing, and a DH- 48 when obtaining the samples by wading. USGS personnel use a D-74 or DH-48. Three sizes of sample nozzles $(1 / 8,3 / 16$, and $1 / 4 \mathrm{inch})$ are interchanged on the D-74 or D-49 depending on flow conditions. A digital and an A-35 graphic stage recorder located $35 \mathrm{ft}$ upstream from the bridge provide a continuous record of streamflow.

SAMPLE ANALYSES: Observer's and USGS samples are weighed, dewatered, and analyzed for concentration in the Montana District Sediment laboratory. No samples were submitted to the Iowa City sediment lab for completeparticle size analysis.

OBSERVER: Name

Street

City

Phone number

EVALUATION OF SAMPLING SITE AND SAMPLING CONDITIONS: Small to moderate amounts of sediment are available from natural sources such as stream banks and valley soils. Streambed material consists primarily of sand, gravel, and cobble, with little shifting except during major flows. The upper Clark Fork generally runs clear during low flow, although some turbidity occurs due to algae and irrigation return flows in the summer. Much larger amounts of sediment are available from sources such as bank erosion, agricultural runoff, and streamside tailings deposited from the Butte-Anaconda mining area. Large volumes of tailings material that were historically deposited along the flood plain during high flows serve as a long-term source of contaminated sediment. These sediments are periodically flushed into the Clark Fork during overland runoff, producing large increases in sediment concentration.

The channel is relatively straight for several hundred feet upstream and downstream. The river bends slightly a short distance downstream, whereas it turns abruptly about 250 feet upstream. Most of the stream in the vicinity of the bridge consists of riffles with some shallow pools. The channel is generally about 70-100 feet wide. The left 
bank upstream of the bridge is high and not subject to overflow. The upstream right bank and both downstream banks are low and may overflow during high flows.

RECORD COMPILATION: Stage and Streamflow Record: Continuous stage records were available at this site for the entire year. The stage-discharge relationship was affected by ice: Dec. 18-22, Jan. 5-7, 23 to Feb. 6 and Feb. 26 to March 1. Discharges for these periods were estimated based on adjacent discharge record, A-35 record, observer notes, weather record, water temperature, and comparison with Clark Fork near Galen. Daily mean discharges were computed on the basis of Rating No. 7.

CONCENTRATION AND SEDIMENT LOAD: The observer's sediment concentrations are generally rated good for the entire sampling period, because most daily sample duplicates compared well with each other and with available USGS samples. Additional daily sampling was conducted Feb. 6 because of a mid-winter thaw runoff event.

All concentration values (observer's and USGS) were plotted on the A-35 chart. A continuous concentration curve was drawn on the basis of the plotted points, stage pen trace, notes on river conditions, climatological data, and general knowledge of the river's sediment characteristics. The maximum instantaneous sediment concentration determined from the constructed concentration curve was $1300 \mathrm{mg} / \mathrm{L}$ on Feb. 8. Daily mean concentrations were determined graphically from the continuous concentration curve.

No days qualified for subdivision. Each daily mean concentration was listed, verified, and entered into storage using WATSTORE program \#475, which merges the sediment data with streamflow to generate a table of daily sediment discharges for the sampling period. The daily values are also stored in PRIME. A summary of sediment data for the 1996 water year is listed in the following tables.

SEDIMENT DATA SUMMARY -- 1996 WATER YEAR:

\begin{tabular}{|l|r|}
\hline \multicolumn{1}{|c|}{ Suspended-sediment samples } & Number \\
\hline \hline Observer single vertical & 163 \\
\hline USGS single vertical (check sample) & 6 \\
\hline USGS cross section & 6 \\
\hline USGS sand-silt break & 6 \\
\hline USGS complete particle size & 0 \\
\hline Range of material finer than $0.062 \mathrm{~mm}$ & $47-70 \%$ \\
\hline
\end{tabular}

\begin{tabular}{|l|r|l|}
\hline \multicolumn{1}{|c|}{ Streamflow } & \multicolumn{1}{c|}{ cfs } & \multicolumn{1}{c|}{ Date } \\
\hline \hline Maximum daily mean & 1,130 & June 11 \\
\hline Minimum daily mean & 50 & Aug. 13 \\
\hline Maximum flow sampled by observer & 1,070 & Feb. 9 \\
\hline Minimum flow sampled by observe & 73 & Aug. 9 \\
\hline Maximum flow sampled by USGS & 1,010 & June 5 \\
\hline Minimum flow sampled by USGS & 172 & July 22 \\
\hline
\end{tabular}

Clark Fork at Deer Lodge, MT

12324200

Page 2 of 3

Figure 18. Example of sediment station analysis --Continued. 


\begin{tabular}{|l|r|l|}
\hline \multicolumn{1}{|c|}{ Suspended-Sediment Concentration } & mg/L & \multicolumn{1}{|c|}{ Date(s) } \\
\hline \hline Maximum daily mean & 835 & Feb. 8 \\
\hline Minimum daily mean & 5 & Aug. $9-11$ \\
\hline Maximum concentration sampled by observer & 388 & Feb. 9 \\
\hline Minimum concentration sampled by observer & 5 & Aug. 9 \\
\hline Maximum concentration sampled by USGS & 976 & Feb. 8 \\
\hline Minimum concentration sampled by USGS & 6 & July 22 \\
\hline
\end{tabular}

\begin{tabular}{|l|c|l|}
\hline \multicolumn{1}{|c|}{ Suspended-Sediment Discharge } & \multicolumn{1}{c|}{ Tons/Day } & \multicolumn{1}{c|}{ Date(s) } \\
\hline \hline Maximum daily & 2,110 & Feb. 8 \\
\hline Minimum daily & .72 & Aug. 11 \\
\hline Maximum sediment discharge sampled by observer & 1,120 & Feb. 9 \\
\hline Minimum sediment discharge sampled by observer & .98 & Aug. 9 \\
\hline Maximum sediment discharge sampled by USGS & 2,610 & Feb. 8 \\
\hline Minimum sediment discharge sampled by USGS & 2.8 & July 22 \\
\hline
\end{tabular}

COEFFICIENTS: No coefficients were used to adjust observer sample concentrations because no significant differences between cross-section and single-vertical sample concentrations were evident. Samples collected on 2/8/96 had a coefficient of 0.67 , however river conditions were changing rapidly with much debris flowing. Unstable conditions resulted in poor correlation between the daily station and $\mathrm{x}$-section samples, so this coefficient was not used. All other cross-section/daily station samples with concentrations greater than $30 \mathrm{mg} / \mathrm{L}$ were within $5 \%$ of each other.

REMARKS: Records of daily sediment concentrations are rated fairly good for the entire sampling period. The estimated daily mean concentrations are considered to be reasonably accurate, because of minor stage fluctuations and good comparison between observer and USGS samples. The observer's notes on river conditions at sampling times were very good which aided in the construction of the continuous concentration curve.

Prepared by: K.A. Dodge

Reviewed by: J.H. Lambing
$11-25-96$

01-02-97 
supplies are low, Field Headquarters personnel should contact either the Chief, Hydraulics and Hydrology Unit or Chief, Data Management Unit.

The two or three most recent level notes are included in the current computation folders for each gaging station and are reviewed as part of the record. A level summary should also be included in the computation folder. After the level notes are reviewed by a surface-water record reviewer, the notes are returned to the Field Headquarters where they are backfiled. Historical level notes are located mostly in the District Office but may also be stored in each Field Headquarters or in the International Waters Section.

Crest-stage-gage levels generally are run by personnel in the Hydraulics and Hydrology Unit. Occasionally, Field Headquarters personnel run levels at CSG's and completed level notes are forwarded to the Hydraulics and Hydrology Unit and filed.

\section{Station Descriptions}

Copies of surface-water station descriptions are maintained in the current station-history folders located in each Field Headquarters and the Data Management Unit. Gaging-station folders are filed in downstream order and reservoir-history folders are filed alphabetically. The original descriptions are located in history folders and updated electronically. When updates are needed, the station description is changed in the computer and a new date is written on the description. All changes are made to the computer copy because it is the "base" description. Discontinued-station descriptions are located on microfiche in the District Office or in their history folders. History folders for discontinued stations are stored in the Data Management Unit or the Federal Records Center (FRC) in Denver or Seattle.

\section{Discontinued Stations}

Since 1977, discontinued station files are temporarily backfiled in the Data Management Unit. Field Headquarters files are submitted to the Data Management Unit when a station is discontinued. The station history folders, rating tables and rating curves, and some compilation data for stations discontinued prior to 1977 have been microfilmed. Once microfilmed, the entire station record was inventoried, boxed, and sent to the Denver Federal Records Center. Data on microfiche for current and discontinued station records are stored in the District Office. Data for all Hudson Bay gaging stations (Part 5) are filed in the International Waters Section.

\section{Map Files}

USGS topographic maps are the standard maps for surface-water activities. Field Headquarters have topographic maps for their field areas. The District Office has complete statewide 7.5- and 15-minute map coverage. Additional topographic maps in Helena include maps at scales of 1:100,000 and 1:250,000. Some maps of Canadian provinces also are available. The District Librarian is responsible for ensuring that the maps are maintained in reliable order. At least one copy of each map should remain in the map files at all times. Extra copies located in file drawers may be used for field trips or office computation and can be written on. The District Librarian is contacted if a copy of a map is needed.

\section{Archiving}

All WRD personnel are directed to safeguard all original field records containing geologic and hydrologic measurements and observations. Selected material not maintained in Field Headquarters is placed in archival storage. The types of original data that should be archived include, but are not limited to, recorder charts and tapes, original data and edited data, observer's notes and readings, station descriptions, analyses, and other supporting information (Water Resources Division memorandum 92.59 and Hubbard, 1992, p. 12). The WRD and FRC have agreed to archive original-data records (memorandum from the Chief, Branch of Operational Support, May 7, 1993).

The District sends surface-water information to FRC every 5 years. The Chief, Data Management Unit is responsible for deciding what information is sent to FRC and for ensuring that the information is properly packed and logged and that it is received by FRC. Detailed information on records that have been placed in archival centers is retained by the Chief, Data Management Unit in accordance with Water Resources Division memorandum 77.83. Personnel who have questions concerning archiving procedures should address their questions to the Chief, Data Management Unit. Personnel who receive requests for information that require accessing archived records should contact Data Management Unit personnel and identify the needed records by station number, name, and water year. A 2-week turnaround time is common for retriev ing archived records. 


\section{Communication of New Procedures}

New or updated OSW and District surface-water policies are communicated verbally and in writing to personnel through Office of Surface Water memoranda, electronic mail, or group meetings. The Chief, HSAS is responsible for making District personnel aware of policy changes.

\section{Sediment-Data Storage}

Short-term storage of sediment data is maintained by the person analyzing the record. Long-term storage is in the District's water-quality files. Copies of graphic charts, laboratory analyses, and computational sheets are kept in the sediment files. The District Sediment Specialist ensures the files are complete. Data Management Unit personnel or the person working the record enters sediment data into the computer data base. The Chief, Data Management Unit is responsible for ensuring that appropriate data are included in the long-term computer storage.

\section{MANAGEMENT OF DATA BASE}

Surface-water data have been collected by personnel of WRD for more than 100 years and stored in computer data bases for more than 20 years. Proper storage and maintenance of surface-water data are critical components in the effective utilization of those data.

The Chief, Data Management Unit is responsible for the ADAPS data base, including electronic logger data files, and the paper-copy storage of surface-water data. Daily surface-water discharge, sediment, and water temperature data stored in ADAPS, once reviewed and certified as meeting USGS computation and publication standards, are flagged as final and cannot be changed without authorization. Authorization to change the data can be obtained by contacting the Chief, Data Management Unit or the District Computer Specialist. Once finalized, the ADAPS-flagged daily values data are submitted to WATSTORE in Reston, Virginia. for:

The District Computer Specialist is responsible

1. Running backups regularly--no more than 1 day's worth of work should ever be lost;

2. Storing a recent copy of backups offsite to protect data in case of fire or water damage;

3. Retaining copies of ADAPS data which have been archived onsite and offsite and copying archived backups as necessary to ensure that backups are usable; and

4. Providing ability to restore backed-up or archived data as required by data users.

Surface-water paper files for individual stations are stored in each Field Headquarters. A complete backfile of surface-water and water-quality data is located in the Data Management Unit. These data are periodically submitted to FRC for storage. See "File Folders for Surface-Water Stations," "Station Descriptions," and "Archiving" for more information.

\section{PUBLICATION OF SURFACE-WATER DATA}

The act of Congress (Organic Act) that created the U.S. Geological Survey in 1879 established the Survey's obligation to make public the results of its investigations and research (U.S. Geological Survey, 1986, p. 4). Fulfilling this obligation includes publishing surface-water data and the interpretive information derived from the analyses of surface-water data.

\section{Publication Policy}

The WRD has created specific policies pertaining to publication and interpretation of data. All WRD personnel are required to abide by those policies. A summary of goals, procedures, and policies are presented in U.S. Geological Survey (1986, p. 4-37).

All final information obtained through investigations and observations by the staff of the USGS or by its contractors must be held confidential and not be disclosed until the information is made available to the public, impartially and simultaneously, through Director-approved formal publication or other means of public release, except to the extent that such release is mandated by law (U.S. Geological Survey, 1986, p. 14). However, hydrologic measurements resulting from observations and laboratory analyses, after they have been reviewed for accuracy by designated WRD personnel, have been excluded from these requirements (U.S. Geological Survey, 1986, p. 15).

All interpretive writings in which the USGS has a proprietary interest, including abstracts, letters to the editor, and all writings that show the author's title and USGS affiliation, must be approved by the Director before release for publication. The objectives of the Director's review are to final-check the technical quality of the writing and to make certain that it meets USGS publication standards and is consistent with policies of the USGS and Department of the Interior. Director's approval ensures that each publication or 
writing (1) is impartial and objective, (2) has conclusions that do not compromise the USGS's official position, (3) does not take an unwarranted advocacy position, and (4) does not criticize or compete with other governmental agencies or the private sector (U.S. Geological Survey, 1991, p. 10).

\section{Types of Publications}

Various types of book publications released by the USGS contain surface-water data and data analyses. Publications of the formal series include WaterSupply Papers, Professional Papers, Bulletins, Circulars, Techniques of Water-Resources Investigations, Special Reports, and Selected Papers in the Hydrologic Sciences (U.S. Geological Survey, 1986, p. 42). Publications in the informal series include Water-Resources Investigations Reports, Open-File Reports, and Administrative Reports (U.S. Geological Survey, 1986, p. 52). Included in the Open-File Report series are data reports. Surface-water data collected by the District are published each year in a hydrologic data report in the annual series titled "U.S. Geological Survey Water-Data Reports." Factors considered by the District when deciding the best form of publication for presenting various types of information are described in Green (1991, p. 14).

\section{Review Process}

Procedures for publication and requirements for review of manuscripts prepared by WRD personnel are summarized in U.S. Geological Survey (1991, p. 3641). The Montana District fulfills those requirements for review and approval of reports prior to printing and distribution. All reports written by USGS scientists in connection with their official duties must be approved by the originating Division and the Director. At least two technical reviews of each report are required by WRD (U.S. Geological Survey, 1991, p. 36). Competent and thorough editorial and technical review is the most certain way to improve and assure the high quality of the final report (Moore and others, 1990, p. 24). Principles of editorial review and responsibilities of reviewers and authors are presented in Moore and others (1990, p. 24-49). In the Montana District, OpenFile Reports are required to receive editorial and technical review, and are reviewed for policy and reproducibility.

Data Management Unit personnel utilize several internal steps to ensure integrity of data quality throughout the report-preparation process. Each record manuscript is reviewed and formatted according to
USGS publication standards. Manuscripts are manually proofread after each update, corrections are made to the computer file, and the station is indexed for manageable final book retrieval. Upon completion, the text is interleafed with the surface-water, water-quality, ground-water, and reservoir data and the entire report is reviewed. The Montana District annual data report is approved by the District Chief prior to mailing to the U.S. Government Printing Office.

\section{SAFETY}

Performing work in a manner that ensures the safety of personnel and others is of the highest priority for the USGS and the Montana District. Beyond the obvious negative impact that unsafe conditions can have on personnel, such as accidents and personal injuries, they also can directly affect the quality of surfacewater data and data analysis. For example, errors may be made when an individual's attention to detail is compromised when dangerous conditions create distractions. To permit personnel to be aware of, and follow, established procedures and policies that promote all aspects of safety, the District communicates information and directives related to safety to all personnel through formal and in-house training classes, memoranda, videotapes, and safety magazines. Specific pol icies and procedures related to safety are described in the District Safety Plan or the Montana Orientation Reference Manual. Each employee is responsible for becoming familiar with District safety material, attending specific training classes when offered, and contacting either their supervisor or the District Safety Officer when safety-related questions or concerns arise. Suggestions concerning safety-related issues are encouraged by District management.

The Montana District has a Safety Officer who advises District management and supervisors to ensure that a safe working environment is provided for all employees. Other duties include annual safety program planning and reporting, program implementation, training, accident prevention, safety inspections, reporting hazards, and accident investigations and reports (Water Resources Division memorandum 90.29).

\section{TRAINING}

Ensuring that personnel obtain knowledge of correct methods and procedures is a vital aspect of maintaining the quality of surface-water data and data analysis. By providing appropriate training to person- 
nel, the District increases the quality of work and reduces the source of many potential errors.

A training resource is included in the Montana Orientation Reference Manual. The manual describes ways to obtain training, training procedures, and management alternatives to training. Employees and their supervisors are required to design an Individual Development Plan annually during the performance appraisal interview. However, employee development is an ongoing process requiring continuous review. Employees and supervisors need to discuss both shortterm and long-term training needs and to document these needs. Supervisors furnish copies of the trainingneeds documentation to the Training Officer, who compiles the documentation for the District and meets with the District Chief and District Administrative Officer to develop an annual District training plan. Although most District training needs are identified and prioritized after the appraisal interviews, some training needs may be unforeseen and may need to be completed as soon as possible. Employees and supervisors need to contact the Training Officer as soon as possible when high-priority training needs arise.

Once a training need is identified and a training course scheduled, selected participants and supervisors are notified in writing. At this time, the employee should be certain that form SF-182, Request, Authorization, Agreement and Certification of Training, is completed and signed by appropriate personnel. If the employee is unable to attend the training, the supervisor should be notified immediately so an alternate participant can be selected. Nomination for training does not guarantee selection.

\section{SUMMARY}

The quality-assurance plan for surface-water activities of the Montana District outlines the field and office responsibilities of personnel for assuring that technical quality and reliability of surface-water data will be maintained. All individuals involved in surface-water activities are responsible for implementing QA through adherence to designated practices and policies. Supervisors and project leaders assume much of the responsibility for implementation; however, the District Chief has the ultimate responsibility.

This report describes the policies and qualityassurance practices followed by the Montana District for the collection, processing, analysis, maintenance, management, and publication of surface-water data. Specific types of surface-water data discussed include stage, streamflow, and sediment.
Collection of reliable and accurate surface-water data is promoted by a program of careful inspection and maintenance of gages and measurement equipment. Processing and analysis of stage, streamflow, and sediment data associated with the computation of streamflow and sediment records are described in terms of QA for the operation of gaging stations, crest-stage gages, and daily sediment stations. The maintenance section of this report includes descriptions of how information related to surface-water data are organized and maintained. Management of the data base emphasizes that proper storage and maintenance of surfacewater data are critical components in the effective utilization of those data. To ensure integrity of data quality, publication of surface-water data is described in terms of policy, types of publications, and the manuscript-review process. In addition, the QA plan describes issues related to employee safety and training.

\section{REFERENCES CITED}

Arcement, G.J., and Schneider, V.R., 1989, Guide for selecting Manning's roughness coefficients for natural channels and flood plains: U.S. Geological Survey Water-Supply Paper 2339, $38 \mathrm{p}$.

Barnes, H.B, 1967, Roughness characteristics of natural channels: U.S. Geological Survey Water-Supply Paper $1849,213 \mathrm{p}$.

Benson, M.A., and Dalrymple, Tate, 1967 , General field and office procedures for indirect discharge measurements: U.S. Geological Survey Techniques of WaterResources Investigations, book 3, chap. A1, 30 p.

Bodhaine, G.L., 1982, Measurement of peak discharge at culverts by indirect methods: U.S. Geological Survey Techniques of Water-Resources Investigations, book 3 , chap. A3, 60 p.

Buchanan, T.J., and Somers, W.P., 1969, Discharge measurements at gaging stations: U.S. Geological Survey Techniques of Water-Resources Investigations, book 3, chap. A8, 65 p.

Carter, R.W., and Davidian, Jacob, 1968, General procedures for gaging streams: U.S. Geological Survey Techniques of Water-Resources Investigations, book 3, chap. A6, $13 \mathrm{p}$.

Corbett, D.M., and others, 1962, Stream-gaging procedure, A manual describing methods and practices of the Geological Survey: U.S. Geological Survey WaterSupply Paper 888, 245 p.

Dalrymple, Tate, and Benson, M.A., 1967, Measurement of peak discharge by the slope-area method: U.S. Geological Survey Techniques of Water-Resources Investigations, book 3, chap. A2, 12 p. 
Davidian, Jacob, 1984, Computation of water-surface profiles in open channels: U.S. Geological Survey Techniques of Water-Resources Investigations, book 3, chap. A15, 48 p.

Edwards, T.K., and Glysson, G.D., 1988, Field methods for measurement of fluvial sediment: U.S. Geological Survey Open-File Report 86-531, 118 p.

Fulford, J.M., 1994, User's guide to SAC, a computer program for computing discharge by slope-area method: U.S. Geological Survey Open-File Report 94-360, $31 \mathrm{p}$.

1995 , User's guide to the culvert analysis program:

U.S. Geological Survey Open-File Report 95-137, 69 p.

Green, J.H., 1991, WRD project and report management guide: U.S. Geological Survey Open-File Report 91-224, $152 \mathrm{p}$.

Guy, H.P., 1969, Laboratory theory and methods for sediment analysis: U.S. Geological Survey Techniques of Water-Resources Investigations, book 5, chap. C1, $58 \mathrm{p}$.

1970, Fluvial sediment concepts: U.S. Geological Survey Techniques of Water-Resources Investigations, book 3, chap. $\mathrm{Cl}, 55 \mathrm{p}$.

Guy, H.P., and Norman, V.W., 1970, Field methods for measurement of fluvial sediment: U.S. Geological Survey Techniques of Water-Resources Investigations, book 3, chap. C2, 59 p.

Hubbard, E.F., 1992, Policy recommendations for management and retention of hydrologic data of the U.S. Geological Survey: U.S. Geological Survey OpenFile Report 92-56, 32 p.

Hulsing, Harry, 1967, Measurement of peak discharge at dams by indirect methods: U.S. Geological Survey Techniques of Water-Resources Investigations, book 3, chap. A5, 29 p.

Kennedy, E.J., 1983, Computation of continuous records of streamflow: U.S. Geological Survey Techniques of Water-Resources Investigations, book 3, chap. A13, $53 \mathrm{p}$.

1984, Discharge ratings at gaging stations: U.S. Geological Survey Techniques of Water-Resources Investigations, book 3, chap. A10, $59 \mathrm{p}$.

1990, Levels at streamflow gaging stations: U.S. Geological Survey Techniques of Water-Resources Investigations, book 3, chap. A19, $31 \mathrm{p}$.

Kilpatrick, F.A., and Schneider, V.R., 1983, Use of flumes in measuring discharge: U.S. Geological Survey Techniques of Water-Resources Investigations, book 3 , chap. A14, $46 \mathrm{p}$.

Knott, J.M., Glysson, G.D., Malo, B.A., and Schroder, L.J., 1993, Quality assurance plan for the collection and processing of sediment data by the U.S. Geological Survey, Water Resources Division: U.S. Geological Survey Open-File Report 92-499, 18 p.
Knott, J.M, Sholar, C.J., and Matthes, W.J., 1992, Quality assurance guidelines for the analysis of sediment concentration by the U.S. Geological Survey sediment laboratories: U.S. Geological Survey Open-File Report 92-33, $22 \mathrm{p}$.

Lambing, J.H., and Dodge, K.A., 1993, Quality assurance for laboratory analysis of suspended-sediment samples by the U.S. Geological Survey in Montana: U.S. Geological Survey Open-File Report 93-131, 38 p.

Marsh-McBirney, Inc., 1994, Flo-Mate manual, 43 p.

Matthai, H.F., 1967, Measurement of peak discharge at width contractions by indirect methods: U.S. Geological Survey Techniques of Water-Resources Investigations, book 3, chap. A4, $44 \mathrm{p}$.

Moore, J.E, Aronson, D.A., Green, J.H., and Puente, Celso, 1990, Report planning, preparation, and review guide: U.S. Geological Survey Open-File Report 89-275, 81 p.

Moreland, J.A., 1995, Quality assurance plan for waterresources activities of the U.S. Geological Survey in the Montana District, 1995: U.S. Geological Survey OpenFile Report 91-194, 29 p.

Porterfield, George, 1972, Computation of fluvial-sediment discharge: U.S. Geological Survey Techniques of Water-Resources Investigations, book 3, chap. C3, $66 \mathrm{p}$.

Rantz, S.E., and others, 1982, Measurement and computation of streamflow, volumes 1 and 2: U.S. Geological Survey Water-Supply Paper 2175, 631 p.

Shearman, J.O., 1990, User's manual for WSPRO--A computer model for water surface profile computations: Federal Highway Administration Report FHWA-IP-89027, $187 \mathrm{p}$.

Smoot, G.F., and Novak, C.E., 1968, Calibration and maintenance of vertical-axis type current meters: U.S. Geological Survey Techniques of Water-Resources Investigations, book 8, chap. B2, $15 \mathrm{p}$.

U.S. Geological Survey, 1966, Leveling--Instructions for field operations and office computations in second- and third-order leveling, Part $2 \mathrm{E}$ of Book 2 of Topographic instructions of the United States Geological Survey: $81 \mathrm{p}$.

1986, Water Resources Division publication guide; Volume I, Publications policy and text preparation, $2 \mathrm{~d}$ ed., revised by D.W. Alt and K.T. Iseri: U.S. Geological Survey Open-File Report 87-205, 429 p.

1991, Suggestions to authors of the reports of the United States Geological Survey, 7th ed., revised and edited by W.R. Hansen: U.S. Geological Survey Special Book Publication, 289 p.

issued annually, Water resources data, Montana. 